\title{
CRITERIOS Y VALORACIONES POLITICAS DE LA PRENSA
}

\author{
Ignacio María Beobide Ezpeleta
}

\begin{abstract}
Sumario: 1. Introducción. 2. Contexto electoral. 3. Análisis de los editoriales: datos y contenidos. 4. Análisis de las colaboraciones: consideraciones previas y datos. 4.1. Presupuestos teóricos del nacionalismo o nacionalismo vasco. 4.2. La definición del problema electoral y de Euskadi. 4.3. La legislatura o futuro postelectoral. 5. La opinión de la prensa: Las colaboraciones ante los partidos políticos. 6. Conclusiones.
\end{abstract}

\section{Introducción}

La prensa diaria desarrolla un papel relevante ante el quehacer político, sea éste la actividad de los órganos fundamentales del Estado y de la Unión Europea —actividad parlamentaria, de gobierno o judicial一, la vida de los partidos políticos, la función de las ideologías o las elecciones. Su labor es múltiple: información, interpretación, valoración, creación y transmisión de opinión política.

El objetivo de este trabajo es analizar el papel de la prensa en cuanto fuente de interpretación y valoración de los fenómenos políticos, cuyo fin último es crear y trasmitir opinión política. Más en concreto, se trata de estudiar la interpretación y creación de opinión sobre las ideologías, objetivos, estrategias y programas de los partidos. Y dentro de este apartado interesa la versión de la prensa sobre el nacionalismo vasco y su discurso político, el discurso de legitimación de su acción y proyecto político. Esta unidad del nacionalismo supone coincidencias substanciales entre las diversas versiones nacionalistas en lo que se refiere al meollo del nacionalismo, pero no olvida las diferencias, que existen entre ellos, sean esenciales o no. No me refiero, por supuesto, a versiones del nacionalismo de intelectuales o grupos sociales, sino, en exclusiva, a la de los partidos nacionalistas vascos, entendiendo por tales los que así se consideran expresamente.

Ya que la petición del voto obliga a los partidos políticos a justificar y argumentar semejante pretensión, los períodos electorales se convierten en la democracia en el escaparate más ilustrativo y llamativo de sus glorias y vergüenzas. Por eso, el momento elegido para el análisis 
de este trabajo es el de las elecciones. Los periódicos diarios son analizados en sus respuestas a las intervenciones de los partidos políticos en su lucha por el voto. En lo fundamental, toda la prensa coincide en la crónica de una campaña electoral, sin embargo la interpretación y valoración de las informaciones, no obstante algunas coincidencias, importantes en ciertos casos, son muy distintas.

Más allá de la información, los editoriales y las colaboraciones firmadas son agentes directos, junto a los partidos, políticos, programas y propaganda, en la lucha electoral. Argumentan; critican; desvelan, ocultan o falsifican la realidad; denuncian o practican la perversión del lenguaje político; forman o deforman; ideologizan o contribuyen al buen juicio. En bastantes ocasiones, los silencios y omisiones de la prensa son más graves y más dañinos que las peores interpretaciones. Al analizar la prensa como fuente de opinión, distinguiré entre los editoriales y los artículos firmados. De esta manera, se pondrá de relieve la opinión del periódico y la de sus colaboradores, pudiendo, así, conocer los mensajes y los argumentos que el periódico transmite y, también, el grado de apertura, de libertad y de pluralismo del periódico, además de la neutralidad o mayor o menor afinidad con un partido, una causa, una ideología y un voto.

La campaña seleccionada para este estudio es la de las elecciones autonómicas vascas al Parlamento de Vitoria de 2001, tal vez, la mejor ocasión desde la transición y las primeras elecciones de 1977 para captar el enfrentamiento radical, sin contemplaciones, entre el nacionalismo vasco y una oposición decidida y animada a presentar una batalla frontal al nacionalismo, convencida del error de la transición de creer que los nacionalismos eran movimientos ilustrados de libertad y modernidad.

Los partidos nacionalistas de 2001 son el Partido Nacionalista Vasco, Eusko Alkartasuna y Euskal Herritarrok, y la prensa analizada — que obedece a los criterios de periódicos más leídos, inspiración nacional o nacionalista y ámbito de difusión territorial general o regional- son $E l$ Correo, El Mundo, El País, Deia y Gara.

La información de los datos de la campaña electoral sobre la que se basan los análisis realizados se reduce en este artículo al mínimo necesario e imprescindible para la comprensión de los mismos.

Dos cuestiones conviene aclarar con carácter previo a este estudio: el contenido nuclear del nacionalismo vasco y la evolución del voto desde la transición. El nacionalismo vasco defiende una ideología política cuyo núcleo esencial lo constituye la afirmación de que la nación es el sujeto último de la titularidad originaria del poder político y la razón de su legitimidad. Aunque aparentemente se invoquen otros argumentos, todos conducen a la misma matriz. El carácter normativo de este contenido se traduce en la reivindicación, como mínimo, de la soberanía polí- 
tica para la nación. La nación es, pues, el argumento o la razón de la acción política nacionalista, cuya operatividad exige en la práctica la añadidura de la definición territorial y la coincidencia de las fronteras políticas con las culturales. Para los partidos nacionalistas, Euskal Herria es una nación con derecho y deber de organizarse en Estado independiente y en este sentido se utiliza en el trabajo el término nación y su ideología, el nacionalismo. Poco importa que esta versión nacionalista de la nación y de sus exigencias políticas no sea un concepto científico, que permita la descripción empírica de manera objetiva de la realidad social. El tema, ya muy estudiado, no es objeto de este trabajo. Baste decir en este sentido que no es otra cosa que una interpretación de la realidad, una pretensión de construcción social, una representación imaginada de la realidad social o una proyección de una supuesta unidad social, que sirve de base a un proyecto político de conquista del poder, cuya objetividad no se da en la adecuación con la realidad social, sino en su mera existencia de representación imaginada o pretensión de construcción social y en su aceptación como creencia política.

La evolución del número de votos y escaños de los partidos nacionalistas en elecciones autonómicas, considerados como un bloque, ha seguido un proceso descendente en el período que va desde las elecciones de 1986 hasta las de 2005 inclusive, si bien en estas últimas la pérdida de un escaño va acompañada de una muy leve recuperación en $\operatorname{votos}^{1}$. Tras las elecciones autonómicas de 1980, 1984 y 1986, en las que el nacionalismo parecía ascender hacia una total hegemonía de manera imparable, las elecciones de 1990 supusieron un cambio de orientación, que medido en escaños ha perdurado hasta 2005. Este descenso del nacionalismo parece haber ejercido una notable influencia en la actitud atrevida y confiada en el éxito de una alternancia en el gobierno de la Comunidad Autónoma Vasca, con la que la oposición a los partidos nacionalistas planteó, especialmente, las elecciones autonómicas de 2001, y, en menor medida, las de 2005.

La máxima diferencia en votos entre partidos nacionalistas y no nacionalistas, siempre a favor del nacionalismo, es la de 1986 con un total de 428.422. Las máximas diferencias en escaños pertenecen a 1980 con 24 escaños en un Parlamento de 60 y con 29 escaños en 1986 en un Parlamento de 75 escaños. La mínima diferencia en votos se produce en 2001 con 88.371 votos, ya que un leve ascenso del nacionalismo en 2005

1 En las elecciones generales es más claro el descenso del nacionalismo. La recuperación del voto por los partidos de ámbito general o nacional, fundamentalmente el PSOE y el PP, les ha llevado a ser mayoritarios en las tres últimas elecciones generales, recuperando el triunfo obtenido en las elecciones de 1977. 
deja la diferencia e 92.661 votos. Por el contrario, las mínimas diferencias en escaños son la de 2001 con 5 escaños y 2005 con 3 escaños.

Los resultados de las elecciones autonómicas vascas en votos (V) y escaños (E) por bloques ${ }^{2}$ se pueden observar en el siguiente cuadro ${ }^{3}$ :

\begin{tabular}{llrrrrrrrr}
\hline & & 1980 & 1984 & 1986 & 1990 & 1994 & 1998 & 2001 & 2005 \\
\hline \multirow{2}{*}{ Nacionalistas } & Votos & 590.691 & 694.238 & 776.706 & 670.919 & 575.629 & 682.958 & 747.361 & 646.961 \\
& Escaños & 42 & 49 & 52 & 50 & 41 & 41 & 40 & 40 \\
No & Votos & 288.912 & 363.352 & 348.284 & 321.926 & 442.730 & 567.607 & 658.990 & 554.300 \\
nacionalistas & Escaños & 18 & 26 & 23 & 25 & 34 & 34 & 35 & 36 \\
\hline
\end{tabular}

El cuadro de porcentajes sobre el censo desde 1980 hasta 2005 es el siguiente:

\begin{tabular}{lrrrrrrrr}
\hline & 1980 & 1984 & 1986 & 1990 & 1994 & 1998 & 2001 & 2005 \\
\hline Nacionalistas & 37,98 & 43,80 & 46,77 & 39,74 & 32,91 & 37,49 & 41,21 & 35,95 \\
No nacionalistas & 18,57 & 22,91 & 20,96 & 19,08 & 25,31 & 31,16 & 36,64 & 30,80 \\
Diferencia & 19,41 & 20,89 & 25,81 & 20,66 & 7,6 & 6,33 & 4,57 & 5,15 \\
\hline
\end{tabular}

En el siguiente cuadro, en el que se recogen los porcentajes de los bloques según los votos a las candidaturas y sus diferencias, se comprueba, como no podía ser menos, la misma tendencia con tantos por cientos más elevados:

\begin{tabular}{llllllllr}
\hline & 1980 & 1984 & 1986 & 1990 & 1994 & 1998 & 2001 & 2005 \\
\hline Nacionalistas & 64,46 & 64,63 & 67,88 & 65,98 & 56,64 & 54,61 & 52,84 & 53,49 \\
No nacionalistas & 31,53 & 33,83 & 30,44 & 31,66 & 43,41 & 45,38 & 46,99 & 45,78 \\
Diferencia & 32,93 & 30,8 & 37,44 & 34,32 & 13,03 & 9,23 & 5,85 & 7,71 \\
\hline
\end{tabular}

El cuadro de la evolución de los porcentajes por escaños y sus diferencias observa la misma tendencia desde 1986, tendencia que se extiende, también, a las elecciones de 2005:

\footnotetext{
2 Los bloques los constituyen, por un lado, PNV, EA, HB (o siglas posteriores) y Aralar, y por el otro, PP, PSE-EE, IU y UA. El criterio es la autodefinición de cada partido.

3 Archivo de resultados electorales 1977-2005, Gobierno Vasco, Departamento de Interior, Dirección de Procesos Electorales (http://www9.euskadi.net/q93TodoWar/q93Indice.jsp. Ultima consulta: 12.12 .2005$)$ y elaboración propia. La misma fuente se utiliza para todos los datos electorales. El número de escaños del Parlamento Vasco es de 75, salvo en 1980, que era de 60.
} 


\begin{tabular}{lcrrrrrrr}
\hline & 1980 & 1984 & 1986 & 1990 & 1994 & 1998 & 2001 & 2005 \\
\hline Nacionalistas & 70 & 65,33 & 69,33 & 66,66 & 54,66 & 54,66 & 53,33 & 52 \\
No nacionalistas & 30 & 34,66 & 30,66 & 33,33 & 45,33 & 45,33 & 46,66 & 48 \\
Diferencia & 40 & 30,67 & 38,67 & 33,33 & 9,33 & 9,33 & 6,67 & 4 \\
\hline
\end{tabular}

La evolución de cada uno de los partidos nacionalistas actuales (no se tiene en cuenta a Euskadiko Eskerra integrada ahora en el PSE) en votos, tanto por cientos y escaños al Parlamento Vasco es la siguiente:

\begin{tabular}{|c|c|c|c|c|c|c|}
\hline Año & Censo & Abstención & $\begin{array}{c}\text { PNV } \\
\text { (en } 2001 \text { y } \\
2005 \text { en } \\
\text { coalición } \\
\text { con EA) }\end{array}$ & $\begin{array}{c}\text { HB } \\
\text { (EH- PCTV) }\end{array}$ & $\begin{array}{c}\text { EA } \\
\text { (en } 2001 \text { y } \\
2005 \text { en } \\
\text { coalición } \\
\text { con PNV) }\end{array}$ & ARALAR \\
\hline \multirow[t]{2}{*}{1980} & 1.554 .527 & $\begin{array}{c}625.476 \\
(40,24 \%)\end{array}$ & $\begin{array}{c}349.102 \\
(38,10 \%)\end{array}$ & $\begin{array}{c}151.636 \\
(16,55 \%)\end{array}$ & & \\
\hline & & & $25(41,66 \%)$ & $11(18,33 \%)$ & & \\
\hline \multirow[t]{2}{*}{1984} & 1.584 .540 & $\begin{array}{c}499.236 \\
(31,56 \%)\end{array}$ & $\begin{array}{c}451.178 \\
(42,01 \%)\end{array}$ & $\begin{array}{c}157.389 \\
(14,65 \%)\end{array}$ & & \\
\hline & & & $32(42,66 \%)$ & $11(14,66 \%)$ & & \\
\hline \multirow[t]{2}{*}{1986} & 1.660 .143 & $\begin{array}{c}504.328 \\
(30,38 \%)\end{array}$ & $\begin{array}{c}271.208 \\
(23,71 \%)\end{array}$ & $\begin{array}{c}199.900 \\
(17,47 \%)\end{array}$ & $\begin{array}{c}181.175 \\
(15,84 \%)\end{array}$ & \\
\hline & & & $17(22,66 \%)$ & $13(17,33 \%)$ & $13(17,33 \%)$ & \\
\hline \multirow[t]{2}{*}{1990} & 1.687 .936 & $\begin{array}{c}658.479 \\
(39,01) \\
\end{array}$ & $\begin{array}{c}289.701 \\
(28,49 \%) \\
\end{array}$ & $\begin{array}{c}186.410 \\
(18,33 \%) \\
\end{array}$ & $\begin{array}{c}115.703 \\
(11,38 \%) \\
\end{array}$ & \\
\hline & & & $22(29,33 \%)$ & $13(17,33 \%)$ & $9(12 \%)$ & \\
\hline \multirow[t]{2}{*}{1994} & 1.749 .250 & $\begin{array}{c}705.165 \\
(40,31 \%) \\
\end{array}$ & $\begin{array}{c}304.346 \\
(29,84 \%) \\
\end{array}$ & $\begin{array}{c}166.147 \\
(16,29 \%)\end{array}$ & $\begin{array}{c}105.136 \\
(10,31 \%)\end{array}$ & \\
\hline & & & $22(29,33 \%)$ & $11(14,66 \%)$ & $8(10,66 \%)$ & \\
\hline \multirow[t]{2}{*}{1998} & 1.821 .608 & $\begin{array}{c}546.600 \\
(30,01 \%) \\
\end{array}$ & $\begin{array}{c}350.322 \\
(28,01 \%) \\
\end{array}$ & $\begin{array}{c}224.00 \\
(17,91 \%) \\
\end{array}$ & $\begin{array}{c}108.635 \\
(8,69 \%)\end{array}$ & \\
\hline & & & $21(28 \%)$ & $14(18,66 \%)$ & $6(8 \%)$ & \\
\hline \multirow[t]{2}{*}{2001} & 1.813 .356 & $\begin{array}{c}381.360 \\
(21,03 \%) \\
\end{array}$ & $\begin{array}{l}604.222^{4} \\
(42,72 \%)\end{array}$ & $\begin{array}{c}143.139 \\
(10,12 \%)\end{array}$ & $\begin{array}{l}604.222^{5} \\
(42,72 \%)\end{array}$ & \\
\hline & & & $33(44 \%)$ & $7(9,33 \%)$ & $33(44 \%)$ & \\
\hline \multirow[t]{2}{*}{2005} & 1.779 .523 & $\begin{array}{l}575.889 \\
(32 \%) \\
\end{array}$ & $\begin{array}{c}468.117 \\
(38,67 \%) \\
\end{array}$ & $\begin{array}{c}150.664 \\
(12,44 \%) \\
\end{array}$ & $\begin{array}{c}468.117 \\
(38,67 \%) \\
\end{array}$ & $\begin{array}{c}28.180 \\
(2,33 \%) \\
\end{array}$ \\
\hline & & & $29(38,66 \%)$ & $9(12 \%)$ & $29(38,66 \%)$ & $1(1,33 \%)$ \\
\hline
\end{tabular}

${ }^{4}$ En estas elecciones y en las del 2005 en coalición con EA.

5 En coalición con el PNV en 2001 y 2005. 


\section{Contexto electoral}

La falta de apoyos parlamentarios impidió acabar la legislatura iniciada en 1998, la que siguió a las elecciones celebradas durante la vigencia del Pacto de Lizarra, y obligó al adelantamiento de la consulta popular. El fin de la tregua de ETA y la actitud de EH contraria a la condena de la violencia están entre los factores que pueden explicar la desaparición de la colaboración entre todos los nacionalistas del Parlamento Vasco, cuya consecuencia fue la de un Gobierno con una minoría inferior a la de la oposición. El Partido Nacionalista Vasco y Eusko Alkartasuna concurrieron a las elecciones formando coalición electoral.

El listado de resultados de las elecciones da lugar a los siguientes cuadros:

\begin{tabular}{lr}
\hline Censo: & 1.813 .356 \\
Votantes & 1.431 .996 \\
Nulos & 6.219 \\
Válidos & 1.425 .777 \\
Blancos & 11.508 \\
V. candidaturas & 1.414 .269 \\
Abstención & $21,03 \%$ \\
Escaños & 75 \\
\hline
\end{tabular}

\begin{tabular}{lrrr}
\hline Partidos & \multicolumn{1}{c}{ Votos } & \multicolumn{1}{c}{$\%$} & Escaños \\
\hline PP & 326.933 & $23,12 \%$ & 19 \\
EB-IU & 78.862 & $5,58 \%$ & 3 \\
PSE-EE/PSOE & 253.195 & $17,90 \%$ & 13 \\
EH & 143.139 & $10,12 \%$ & 7 \\
EAJ-PNV/EA & 604.222 & $42,72 \%$ & 33 \\
Otros & 7.918 & $0,56 \%$ & 0 \\
\hline
\end{tabular}

La batalla electoral, a pesar de concurrir otros partidos políticos, se libró entre el Partido Popular, el Partido Socialista, Euskal Herritarrok y la Coalición Nacionalista con unas expectativas de triunfo muy abiertas, lo que supuso una novedad en elecciones autonómicas. A diferencia de lo ocurrido en las elecciones generales de 1977, 1996, 2000 y 2004, en las que se había producido el triunfo de los partidos de ámbito general o nacional, nunca la suma de votos de estos partidos había ganado en unas elecciones autonómicas. Es más, ni siquiera se había confiado en ello. Unicamente el PSE había obtenido más escaños que nin- 
gún otro partido en las elecciones de 1986, en las que, por otra parte, la suma de escaños nacionalistas alcanzó el total de 52 en un Parlamento de 75 .

El contexto social y político en que tuvieron lugar las elecciones fue angustioso y agresivo, principalmente, aunque no exclusivamente, por causa de la violencia de ETA, que negaba potencialmente la vida, libertades y derechos a los no nacionalistas. Las campañas del PP y PSE son una buena prueba de ello. Lo mismo cabe deducir de la campaña de la coalición, aunque en ocasiones se tratara de ocultarlo. No se debe olvidar que, en pleno siglo XXI y dentro de la Unión Europea, la seguridad universal de las personas, que es la primera condición de legitimidad no ya del Estado de Derecho, sino del mero Estado, estaba en entredicho, como lo estaba, aún más, la garantía de los derechos fundamentales, la esencia misma del Estado de Derecho. Hobbes y Locke se habrían quedado pasmados si hubieran visto, más de tres siglos después, una situación en la que el orden y la seguridad, por un lado, y la vida y libertades, por otro, pudieran ser, todavía, objeto de división entre quienes se consideraban contrarios a la violencia. Pero estaba de por medio el argumento de la nación.

La coalición nacionalista utilizó el argumento de la independencia y soberanía de la nación vasca para pedir el voto, pero lo hizo en una proporción muy inferior a otros argumentos, en concreto, ni siquiera llegó al 7\% del total de la campaña. Esto no impidió que la nación estuviera presente como una constante argumental a lo largo de todo el proceso electoral. Este comportamiento sugiere una interpretación de la mentalidad y conciencia del electorado como insuficientemente nacionalistas para ganar con tales elementos las elecciones; así mismo, muestra desconfianza en la eficacia electoral de sus propias convicciones.

La coalición nacionalista substituyó el argumento positivo del nacionalismo por el negativo, el del «enemigo del pueblo vasco, de la nación vasca y de lo vasco», que, si bien incluía a ETA y a cuantos apoyaban la violencia, se centró fundamentalmente en el Partido Popular y, secundariamente, por sus coincidencias, en el Partido Socialista de Euskadi/EE, y se personificó en su candidato Jaime Mayor Oreja y, en menor medida, en Nicolás Redondo, el candidato socialista.

El debate electoral se redujo a una lucha entre el nacionalismo español y el nacionalismo vasco, falsamente planteada y contradictoriamente desarrollada, para lo que se utilizaron instrumentos en los que abundaron la inexactitud y la falsedad. Entre ellos destacan: los jurídicos (falsa idea de Constitución favorable a la autoderminación del pueblo vasco, o del Estatuto Vasco como expresión de dos sujetos soberanos, o 
del Derecho Internacional en cuanto fundamento de la autodeterminación de Euskadi); los políticos (tratamiento frívolo y banal, con alguna excepción, de las grandes cuestiones políticas como la independencia, autodeterminación o legitimidad de la violencia del Estado; visión patrimonial de las instituciones vascas; falso origen político de la violencia y del supuesto problema histórico vasco); la ocultación de la realidad (afirmación del aumento de la conciencia nacionalista; negación del reconocimiento de la legitimidad del nacionalismo; infravaloración de la participación de agentes no nacionalistas en el bienestar económico y social; simplificación o rechazo del carácter selectivo de la praxis de la violencia; silencio o negación de la defensa de los valores que hacían coincidir a populares y socialistas; trivialización de la paz como parte del bienestar social; indeterminación del sentido y alcance del diálogo; falsa identificación de la coalición nacionalista como el centro político ante extremos igualmente rechazables; cierta indisciplina de partido); la superioridad del nacionalismo vasco (moralidad, inocencia, eficacia, solidaridad); y, por último, la descalificación expresa de la oposición (búsqueda del enfrentamiento callejero; estrategia de división y ruptura sociales; verdugos, franquistas y antidemócratas populares; antiautonomistas y contrarios a la identidad vasca; interés del PP en la permanencia de ETA y utilización partidista de sus asesinatos; versión rocambolesca de las relaciones, objetivas o no, entre Partido Popular y ETA).

La coalición también utilizó como argumentos electorales el rechazo de la violencia (por convicciones éticas y democráticas y por perjudicial a los intereses vascos y nacionalistas), la interpretación de ETA como totalitaria, la defensa de la vida y la fe inquebrantable en el triunfo electoral ${ }^{6}$.

6 Ver Deia 27-4-2001 (14); Deia 28-4-2001 (14); El Correo 30-4-2001 (16); Gara 30-4-2001 (14); El Mundo 1-5-2001 (8). El Correo 1-5-2001 (18); Deia 1-5-2001 (13); El País 1-5-2001 (14); El Mundo 1-5-2001 (8); Deia 2-5-2001 (13); El Correo 7-5-2001 (24); El Mundo 7-5-2001 (9); El Mundo 8-5-2001 (6); El Correo 9-5-2001 (18); El Correo 11-5-2001 (24 y 25); Gara 10-5-2001 (17); Deia 11-5-2001 (19); El Correo 12-5-2001 (18). El Correo 6-5-2001 (31). El Correo 30-4-2001 (16). El Correo 11-5-2001 (25). El Correo 1-5-2001 (18). Deia 4-5-2001 (12). Correo 12-5-2001 (24). Deia 27-4-2001 (14). El País 9-5-2001 (14). El Mundo 7-5-2001 (9) y El País 7-5-2001 (17). El Correo 5-5-2001 (25). Deia 4-5-2001 (12); El Mundo 4-5-2001 (10). El Correo 7-5-2001 (24). Deia 7-5-2001 (10); Gara 7-5-2002 (13); El País 7-5-2001 (17). El Mundo 2-5-2001 (10). El Correo 1-5-2001 (18); Deia 1-5-2001 (13); Gara 1-5-2001 (16). El Correo 27-4-2001 (20); 28-4-2001 (19); 29-4-2001 (28); 30-4-2001 (16); 1-5-2001 (18); 2-5-2001 (20); 4-5-2001 (22); 5-5-2001 (25); 6-5-2001 (31); 7-5-2001 (24); 8-5-2001 (23); 9-5-2001 (19); 11-5-2001 (24);12-5-2001 (18); Deia 27-4-2001 (14); 30-4-2001 (11); 1-5-2001 (13); 4-5-2001 (12); 5-5-2001 (14 y 15); 6-5-2001 (14); 7-5-2001 (10); 8-5-2001 (17); 11-5-2001 (12); El País 27-4-2001 (16); 1-5-2001 (14); 6-5-2001 (22); 8-5-2001 (1 y 15); 9-5-2001 (14); Gara 27-4-2001 (19); 29-4-2001 
La petición del voto por parte de EH estuvo basada en una campaña esencial y absolutamente nacionalista con cuatro polos de desarrollo, que son, a su vez, consecuencias necesarias o exigencias de la premisa ideológica nacionalista: $1 .^{\circ}$, la proclamación constante de los mitos nacionalistas (comunidad cultural, territorial y política del pueblo o nación vasca) en cuanto justificación y legitimación del objetivo de $\mathrm{EH}$ (soberanía, independencia, Estado vasco, autodeterminación); 2. ${ }^{\circ}$, la descalificación de los otros partidos por enemigos (populares y socialistas) o por traidores y aprovechados (PNV y EA); $3 .^{\circ}$, la remisión al Estado soberano vasco (con la consiguiente repetición del mismo mensaje) para solucionar todos los problemas, desde la identidad nacional hasta la economía y la distribución de la riqueza; y $4 .^{\circ}$, la distorsión o ocultación de la realidad social y política vasca, especialmente en materia de derechos, y la tergiversación de la historia.

La invocación a la condición o identidad social revolucionaria e izquierdista fue, desde el punto de vista formal, puramente residual y nominal. Su uso fue circunstancial, irrelevante y sin ningún tipo de desarrollo. En cuanto a su contenido, fue un misterio.

El fundamento de la soberanía vasca en motivos ajenos a la mítica ideología nacionalista, es decir, en razones sociales y políticas actuales (lucha contra la globalización o defensa de los derechos fundamentales, por ejemplo) fue anecdótica, contradictoria, improcedente y superficial. No hay, por ello, ningún cambio esencial en la presentación de la legitimidad nacionalista en comparación con las opciones del PNV o de EA.

El objetivo inmediato de EH era repetir el Pacto de Lizarra con la coalición nacionalista de acuerdo con la premisa de que sólo un nacionalismo unido podía ser eficaz. Fracasada la vía del diálogo, se buscó el éxito electoral a costa de los votos del PNV, para forzarle, en su debilidad, a la alianza deseada con la amenaza o advertencia de la pérdida del poder de las instituciones en el caso contrario. El objetivo último fue la soberanía identificada con la paz. La violencia, conflicto armado, era la consecuencia del sometimiento de Euskal Herria, es decir, de la ausencia de soberanía.

Los argumentos contra populares y socialistas coincidieron con los utilizados por el PNV y EA: fascismo, franquismo, antivasquismo y miedo a perder los logros conseguidos en cultura, euskera y poder ins-

(18); 30-4-2001 (14); 1-5-2001 (14 y 16); 3-5-2001 (15); 4-5-2001 (17); 5-5-2001 (13); 6-5-2001 (17); 7-5-2001 (22); 8-5-2001 (1 y 12); El Mundo 29-4-2001 (13); 30-4-2001 (11); 1-5-2001 (14); 2-5-2001 (10); 5-5-2001 (13); 7-5-2001 (9); 8-5-2001 (1, 2, 6 y 7). El Correo 27-4-2001 (20); 28-4-2001 (19); 29-4-2001 (12); 1-5-2001 (18); 2-5-2001 (20); 6-5-2001 (31); 9-5-2001 (19); 11-5-2001 (25); 12-5-2001 (20); El País 28-4-2001 (20 y 21); 6-5-2001 (22); 9-5-2001 (14); EL Mundo 2-5-2001 (10); Deia 28-4-2001 (14); 29-4-2001 (12); 2-5-2001 (13); 6-5-2001 (14); 12-5-2001 (11); Gara 28-4-2001 (18); 3-5-2001 (16). 
titucional. Tuvieron la doble finalidad de descalificar a populares y socialistas y, principalmente, de resaltar la traición de la coalición nacionalista al pacto con EH y a la causa de Euskal Herria.

En torno a la autonomía EH expresó su incapacidad para solucionar el problema nacional vasco, la necesidad de utilizarla para avanzar hacia la soberanía y la paz como única justificación, el miedo a perderla y la poco fundamentada afirmación de que los avances en euskera y otros valores vascos se habían producido antes y al margen de la autonomía. Y, en lógica consecuencia con la confusión, el Concierto económico era una manifestación más de la explotación que sufría Euskal Herria.

EH pretendió de una manera emocional dar una imagen épica, de fuerza y cohesión de su electorado, que los votos se encargaron de desmentir, como desmintieron, también, que la autonomía per se con sus intereses no tuviera apoyos y reconocimiento entre sus votantes ${ }^{7}$.

El Partido Popular, desde el primer momento de la campaña, insistió en su objetivo de ser la alternativa política al nacionalismo para ganar la libertad, defender la vida, impedir que el miedo fuera el hecho

7 El Correo 28-4-2001 (24). Gara 27-4-2001 (16); El Correo 27-4-2001 (25); 1-5-2001 (20); El Mundo 27-4-2001 (14); Deia 27-4-2001 (14); 9-5-2001 (15). El Correo 28-4-2001 (24) y Gara 28-4-2001 (17). El País 28-4-2001 (23) y El Mundo 28-4-2001 (11) y 9-5-2001 (14). El Correo 29-4-2001 (34); El País 29-4-2001 (19); Gara 29-4-2001 (15); El Mundo 29-4-2001 (15). El Mundo 9-5-2001 (15). Deia 28-4-2001 (24). El Correo 28-4-2001 (24) y Gara 28-4-2001 (11). El Mundo 8-7-2001 (9). El Correo 8-5-2001 (27); Deia 8-5-2001 (20); Gara 8-5-2001 (15 y 17). Gara 8-5-2001 (15). Gara 29-4-2001 (20). El Mundo 9-52001 (14). El Correo 11-5-2001 (23). El Mundo 11-5-2001 (12); Gara 11-5-2001 (20). El Correo 27-4-2001 (25); Gara 27-4-2001 (16); El Mundo 27-4-2001 (14); Deia 27-4-2001 (17). El Mundo 30-4-2001 (12). Ver El Correo 30-4-2001 (22); Gara 30-4-2001 (15); Deia 30-4-2001 (13). El Correo 1-5-2001 (20). El Correo 1-5-2001 (20). Ver, también, Gara 1-5-2001 (19); El Mundo 1-5-2001 (12). La misma idea en El Mundo 9-5-2001 (14) y Deia 9-5-2001 (23). El Correo 4-5-2001 (28). El Correo 6-5-2001 (36). Ver, también, El Mundo 6-5-2001 (14); El Correo 5-5-2001 (27). El Correo 5-5-2001 (27). Ver, también, Gara 5-5-2001 (12); Deia 5-5-2001 (16). El Correo 9-5-2001 (19). El Mundo 10-4-2001 (13), 10-5-2001 (12); Deia 10-5-2001 (15). El Mundo 12-5-2001 (23). EL Correo 10-5-2001 (24); 11-5-2001 (23); 12-5-2001 (23); El Mundo 10-5-2001 (13); 12-5-2001 (15). Gara 29-4-2001 (15); El Correo 3-5-2001 (23); El Mundo 1-5-2001 (12); 5-5-2001 (15). Gara 2-5-2001 (16); El Correo 6-5-2001 (36); Gara 11-5-2001 (29). El Correo 1-5-2001 (20) y 11-5-2001 (23). Gara 1-5-2001 (17 y 19); 11-5-2001 (20); El Mundo 11-5-2001 (12). El Correo 9-5-2001 (26). Gara 2-5-2001 (16). El Correo 2-5-2001 (29); 4-5-2001 (28); 11-5-2001 (23). El Correo 27-4-2001 (25) y 12-5-2001 (23); Gara 27-4-2001 (16). Gara 27-4-2001 (16); 27-4-2001 (16); El Correo 27-4-2001 (14); 29-4-2001 (34); Deia 27-4-2001 (17); 29-4-2001 (15); El País 29-4-2001 (19); El Mundo 29-4-2001 (11). Correo 8-5-2001 (27). Gara 28-4-2001 (17); 29-4-2001 (20); 8-5-2001 (15); Deia 28-4-2001 (16); 29-4-2001 (15); 5-5-2001 (16); El Correo 28-4-2001 (24); 29-4-2001 (34); 6-5-2001 (36); 8-5-2001 (27); El Mundo 9-5-2001 (14). 
diferencial de Euskadi y conseguir que los violentos dejasen de mandar y matar. Para Mayor Oreja, candidato del Partido Popular a Lehendakari, el adversario no era el Partido Socialista — al que reconoció su apuesta por la defensa de la libertad, la Constitución y el Estatuto-, ni siquiera los nacionalistas moderados - a quienes en repetidas ocasiones les pidió el voto-, sino los radicales, entre los que incluía al EBB presidido por un Arzalluz, creador de miedo y anclado en un pasado de rencor y odio. Mayor centró su actuación en el presidente del PNV, marginando y olvidando habitualmente al candidato de la coalición nacionalista Ibarretxe.

La pretensión popular era derrotar un régimen, el régimen nacionalista, del que las distintas formaciones nacionalistas formaban parte de una u otra manera, bien mediante la ofensiva política de Arzalluz o bien mediante la del terror de ETA. El Pacto de Lizarra era, según la versión del PP, la institución para consolidar el régimen en el que unos mataban y otros dirigían, unos asesinaban y otros mentían. La permanencia nacionalista en el poder aportaría más Pacto de Lizarra, cosa que se estaba tramando, según opinión del PP, a través del intento de una nueva tregua que permitiese realizar al PNV lo que más deseaba, la alianza con EH y ETA, especialmente en el caso de ser necesaria para llegar al gobierno y mantenerse en él. El voto al PNV suponía, pues, apoyar a su actual dirección y prolongar el poder de ETA durante muchos años. ETA, por su parte, había decidido estar en la investidura, y la intervención de Arzalluz, afirmando la inevitabilidad de aceptar los votos de EH, lo confirmaría. El PNV estaba utilizando, una vez más, el fin de la violencia como excusa política mediante pactos con los terroristas orientados a destruir la convivencia. El PNV tenía elaborada una estrategia de convergencia con ETA. Entre ETA y PNV existía una convergencia de raíz. La vinculación entre terrorismo y nacionalismo seguiría dándose, mientras el nacionalismo tuviese el proyecto de separar el País Vasco de España.

Esta presentación de la coalición nacionalista, especialmente el PNV, como parte de un todo compacto e indivisible, es, tal vez, el elemento más destacable de la campaña popular. Según esto, vencer y desalojar a los nacionalistas del Gobierno Vasco era la condición necesaria para derrotar a ETA.

El Partido popular pretendía lograr un Ejecutivo comprometido con el ejercicio democrático del poder, con el autogobierno, con la cultura vasca, con el apoyo a las víctimas y con el fin de ETA, es decir, cerrar la transición en Euskadi. Hacia la mitad de la campaña Mayor mostró su opinión favorable a gobernar con el PSE, aunque no obtuviesen la mayoría absoluta. 
La censura al nacionalismo alcanzó al Concierto Económico por utilizarlo como instrumento de beligerancia con la Unión Europea y contra las Comunidades limítrofes con el País Vasco. La aplicación desmedida y abusiva del mismo y la pasividad del Gobierno Vasco, en opinión de Mayor Oreja, situaron al Concierto al borde del precipicio y llevaron a un tribunal europeo a acusar al régimen fiscal del País Vasco de vulnerar la libre competencia. Su integridad se salvó gracias a la defensa hecha por el Gobierno Español del Partido Popular y a su consideración de régimen fiscal constitucional. El Concierto era para los populares una de las columnas vertebrales de los vascos, pieza clave de la identidad vasca e instrumento primordial de su economía.

Otras críticas denunciaron las mentiras y la infamia de Ibarretxe (Mayor llamó «la mentira de la campaña» a la promesa de no gobernar con los votos de EH y consideró que, aunque no había alianza con el PSE, tendría más decencia que la del PNV con ETA y EH), la incapacidad de los nacionalistas de hacer un país cómodo para todos, el clientelismo institucional, la insensibilidad hacia el sufrimiento de los populares y socialistas amenazados por ETA, el deseo del PNV de ver muerto el Estatuto, el nacionalismo independentista -más propio de los Balcanes que de la Europa del siglo XXI-, la falta de valores y principios, la práctica del mayor y peor pelotazo de vivir del miedo de los demás y la deslealtad y traición democráticas ${ }^{8}$.

Para el PSE las elecciones eran la ocasión para derrotar al fascismo, al fanatismo, a la intransigencia, a la impunidad y al miedo. La alternativa estaba entre la impunidad y la justicia. El triunfo del PNV (la coalición nacionalista para el PSE era prácticamente el PNV) significaría que le había salido gratis la traición de Lizarra, la cesión a ETA de la libertad socialista — no la de los nacionalistas-, y su desprecio a las víctimas; así mismo, el triunfo del PNV acarrearía la potenciación del frente nacionalista, la tibieza policial contra ETA, la persecución social contra los constitucionalistas y el aumento de los exiliados por cuestiones ideológicas, políticas o miedo. Pero el nacionalismo sabía que iba a perder por la deserción de sus votantes, a los que en repetidas ocasiones se les pidió el voto.

$\mathrm{Su}$ proyecto era constitucionalista, estatutario y defensor del cambio tranquilo sin revanchas ni olvidos, que partía del reconocimiento y

8 Ver El Correo 27-4-2001 (21); 28-4-2001 (20); 29-4-2001 (30); 30-4-2001 (15); 1-5-2001 (19); 2-5-2001 (22); 3-5-2001 (19); 4-5-2001 (20); 5-5-2001 (23); 6-5-2001 (30); 7-5-2001 (21); 8-5-2001 (22); 9-5-2001 (20); 10-5-2001 (21); 11-5-2001 (18); 12-5-2001 (19). 
denuncia de la falta de libertad en Euskadi. Ante tal situación no había que hacer distinciones entre la derecha y la izquierda, sino más bien superar las propias siglas de identidad política. Por encima de las diferencias entre derecha e izquierda estaban la vida y la libertad. El PSE pretendía rescatar al euskera del nacionalismo; respetar cultura, lengua y autogobierno vascos y negar toda financiación de organizaciones que pretendiesen superar el Estatuto.

Así mismo el PSE buscaba un Gobierno, aunque fuera en minoría, que recuperase la unidad democrática para instaurar la libertad perdida y ganar a ETA y no para pagarla; un Gobierno que dedicase sus energías a combatir a ETA desde los medios públicos de comunicación, las instituciones democráticas y la política educativa orientada a cortar cualquier elemento de totalitarismo. La unidad contra ETA exigía la renuncia a la violencia y el respeto a la Constitución y al Estatuto. Los socialistas aspiraban a gobernar para que los nacionalistas no sufrieran como ellos; sólo los violentos serían condenados a un «túnel de angustia y fracaso». Redondo — candidato socialista— puso especial interés en ofrecer el apoyo y cobijo de un Gobierno vasco constitucional, estatutario y de unidad democrática a los empresarios afines al nacionalismo, recordándoles que el PNV no era moderación, sino radicalidad. Se prometía un orden público — sin el que era imposible la libertad-, que limpiara las calles del matonismo de ETA y de la inseguridad que habían aumentado durante los dos últimos años de gobierno nacionalista.

A pesar de que la prioridad socialista de la campaña quiso ser la explicación de su proyecto político, la crítica al PNV ocupó buena parte de la misma. Así, su impericia al pactar con ETA y HB, que no trajo más que zonas de impunidad, miedo e inseguridad; su frivolización de la pérdida de libertades de muchos vascos al considerarlas chiquilladas; su baja catadura moral por dejar el Gobierno en manos de ETA, a la que Redondo, por otra parte, responsabilizaba directamente; su responsabilidad política de la violencia; su consideración de personaje sin catadura moral, mentiroso («el gran mentiroso de esta campaña»), desmemoriado, dócil, incapaz y sin energía atribuida a Ibarretxe por diversos motivos como gobernar, negándolo, durante dos años con los votos de Josu Ternera y por sus acusaciones al PSE de sometimiento al PP; la campaña del miedo, campaña apocalíptica, del PNV, por sentirse perdedor; la responsabilidad de Arzalluz y Egibar en dar legitimidad a ETA y a la «kale borroka»; la condición del PNV de haber sido el único partido que no cedió nada en la transición política; el precio político que puso a la paz; el desarrollo de un nacionalismo etnicista, antidemocrático y totalitario; la indecencia y zafiedad de Arzalluz (que representaba 
lo más triste y oscuro de la historia de España) por la acusación de buscar votos con los asesinatos y desear que desapareciese Redondo; y la inculcación en los batzokis del odio a los socialistas y a los constitucionalistas. Fueron ciertas intervenciones de Felipe González y Zapatero las que trataron de suavizar la crítica descarnada contra el nacionalismo del PNV.

La política de pactos era para después de las elecciones, aunque se consideraba imposible (en alguna ocasión se dijo que sería muy difícil) aliarse con el nacionalismo de Estella, de la autodeterminación y de las relaciones con ETA. Un PNV en la oposición tendría que recapacitar para encontrar, de nuevo, a los socialistas. Felipe González defendió la necesidad de recuperar un gran espacio de convivencia con todos los demócratas, que incluía a sus «amigos» del PNV, a quienes pedía rectificar tras su dramático error con ETA. Pero la tesis básica en materia de pactos y gobierno era el entendimiento con el Partido Popular' ${ }^{9}$.

\section{Análisis de los editoriales: datos y contenidos}

El análisis de los editoriales de cada periódico se presenta por separado y el índice de temas es común a todos ellos, ya que su selección viene exigida por la propia prensa, muy coincidente, en general, en este punto. La homogeneidad temática gira en torno a los siguientes puntos: 1. ${ }^{\circ}$, interpretación y valoración del sentido y significado de las elecciones; $2^{\circ}$, violencia y terrorismo: sujetos, objetivos y estrategias para su desaparición; $3 .^{\circ}$, orientación del voto, expresa y directa, tácita e indirecta, tanto a favor como en contra de los partidos o ideologías; . $^{\circ}$, interpretación de los resultados electorales y futuro postelectoral: gobierno, alianzas, gobernabilidad y unidad democrática.

En torno a estos puntos la prensa desarrolla la crítica, rechazo, apoyo y defensa del nacionalismo vasco, que constituye, como ya está di-

9 Ver El Correo 27-4-2001 (22); 28-4-2001 (18); 29-4-2001 (29); 30-4-2001 (20); 1-5-2001 (17); 2-5-2001 (21); 3-5-2001 (20); 4-5-2001 (21); 5-5-2001 (24); 6-5-2001 (29); 7-5-2001 (23); 8-5-2001 (22 у 26); 9-5-2001 (21); 10-5-2001 (20); 11-5-2001 (20); 12-5-2001 (20). No hubo censura del Partido Popular, sino reconocimiento de los valores en los que coincidían. Sí hubo, por el contrario (se puede comprobar en los lugares citados en esta nota), una reducida, pero contundente descalificación de Izquierda Unida y de su candidato, Madrazo. En este sentido se dijo: votar a IU era votar al nacionalismo; IU era el protegido del PNV, la derecha más recalcitrante del país; IU hacía el trabajo sucio del PNV y devolvería el favor de rebajar del 5\% al 3\% el mínimo electoral de votos para sacar escaños con su apoyo en el Parlamento; Madrazo era el tonto útil, que estaba al servicio de quien le pagaba, para justificar que el Pacto de Estella no era nacionalista. 
cho, el objeto de este estudio, en el que coinciden la intención subjetiva del autor y la naturaleza objetiva de las elecciones, cuyo protagonista fue de principio a fin el nacionalismo vasco.

El total de editoriales de los cinco periódicos fue de 147, 41 de los cuales $(27,89 \%)$ tuvieron carácter directamente electoral. El Correo escribió 10 electorales de un total de 33 (34,48\%); El Mundo 11 de 33 (33,33\%); Gara 6 de 19 (31,59\%); Deia 5 de 18 (27,77\%) y El País 9 de $48(18,75 \%)$. Si se tienen en cuenta únicamente los 41 editoriales electorales, el orden de compromiso o atención electoral es el siguiente: El Mundo 11 (26,82\%), El Correo 10 (24,39), El País 9 (21,95), Gara 6 (14,63\%) y, por último, Deia 5 (12,19). Según esto, El Correo dedicó el doble de atención a las elecciones que Deia y algo parecido ocurrió en comparación con Gara. Incluso periódicos de ámbito general como El País y, especialmente, El Mundo, repitieron, más o menos, el comportamiento de El Correo $^{10}$.

El Correo fue el diario que más analizó las elecciones ${ }^{11}$; consideró positiva la convocatoria electoral; llamó a la participación masiva, a la unidad democrática y a la moderación política; interpretó la situación vasca como muy grave en lo que afectaba a instituciones políticas, derechos humanos (vida, seguridad y libertades) y conciencia colectiva (esquizofrénica, satisfecha y falsa); y mostró su confianza en la eficacia de la democracia, de sus instrumentos e instituciones. En su opinión, la sociedad vasca era plural, no uniforme, y las elecciones, una de las más decisivas, eran el instrumento y la ocasión para demostrar lo diverso y lo común y construir una sociedad de personas libres y en paz.

En relación con la violencia hay que decir que toda la campaña fue un discurso contra ella y sus autores. Fanatismo, terrorismo, horror, crueldad, asesinato, sadismo, depravación, dictadura y totalitarismo fueron algunos de los términos utilizados para definir a ETA y sus ac-

10 Algunos editoriales eran indirectamente electorales por la incidencia que determinados comentarios, en ocasiones críticas mordaces, sobre éxitos y fracasos de los gobiernos central o autonómico en materias como política económica, inflación o euskera, podían tener sobre el electorado. Al carecer de conexión expresa con la orientación del voto no se han contabilizado en la cuantificación de los datos, aunque sí se han utilizado en el trabajo. $\mathrm{Su}$, tal vez, soterrada intencionalidad, difícil de probar, por otra parte, hacía razonable tenerlas en cuenta.

11 Los diez editoriales de El Correo son: «Cita ineludible», 27-4-2001 (33); «El debate sobre el debate», 1-5-2001 (7); «Prensa y libertad», 3-5 2001 (29); «Oportunidad ineludible», 6-5-2001 (41); «Votos contra las balas», 7-5-2001 (29); «Sentir cívico», 8-5-2001 (31); «Votar en libertad», 11-5-2001 (31); «Inflación desbocada», 12-5-2001 (27); «Votar es un deber», 13-5-2001 (37); «Realidad inapelable», 14-5-2001 (29). 
tuaciones y anunciar el futuro que esperaba, si los ciudadanos vascos no vencían su intolerancia. El asesinato y la coacción discriminatoria eran, además, factores de insolidaridad, división e incomprensión, aunque no se destacaba que la violencia discriminatoria era factor, por miedo, de adhesión nacionalista. La erradicación de la violencia, la victoria sobre el terrorismo, el miedo y la impotencia fue el objetivo básico y la obsesión de El Correo de principio a fin de la campaña. Y para ello no había otros medios que los votos, la participación, la unidad democrática y el implacable acoso contra los violentos. El resultado sería la única paz posible. El coche-trampa del final de la campaña le llevó al periódico a dejar de lado las opciones de las candidaturas y defender que no había más opción que elegir entre libertad y abatimiento, razón y superchería, vida o sumisión a la pena de muerte.

La orientación del voto necesariamente tenía que estar vinculada a lo que para El Correo era lo fundamental, establecer la paz y la libertad mediante la derrota del terrorismo de ETA. Así, el derecho al voto era un deber cívico contra el terror, el fanatismo, la intolerancia, el etnocentrismo y la xenofobia ideológica.

No consta que El Correo pidiese expresamente el voto para ninguna candidatura; sí, en cambio, para la libertad y la vida. También fue expresa la petición de no votar a la candidatura de Euskal Herritarrok, lo que se hizo en repetidas ocasiones, con la justificación de que el voto a EH era un apoyo a ETA, que avalaba la perpetuación del terrorismo. Ningún voto que favoreciese a ETA. La petición del voto contra el terrorismo, el nacionalismo violento, el etnicismo, los antidemócratas, el fanatismo asesino y la intolerancia fue constante y directo. El Correo lo defendió, además, como respuesta a la creencia de ETA de que los ciudadanos vascos no se atreverían a votar inequívocamente contra el terrorismo. Cada vez que el periódico salía en defensa de los valores de la democracia, la vida y las libertades o se oponía a la construcción nacional etnocéntrica de la colectividad, estaba pidiendo el voto contra ETA y EH, y, en la medida en que la coalición nacionalista participaba de una visión etnocéntrica de la nación vasca, también contra ella, aunque fuera de una manera tácita.

No hubo una palabra directa o expresamente dicha pidiendo el voto para la Coalición Nacionalista o el Partido Popular o el Partido Socialista de Euskadi o Izquierda Unida. Tampoco la hubo para que se les negase el voto. Sin embargo, la crítica desarrollada fue tan desigual que permite concluir que la tesis de El Correo era que, si bien el objetivo electoral lo constituía la derrota de ETA y EH con la consiguiente única exclusión de los violentos de la muerte y destrucción, la responsabili- 
dad política en el pasado inmediato y en el presente era fundamentalmente del Partido Nacionalista Vasco. Apenas hubo crítica al PP (un editorial criticó la política de precios del gobierno del PP) y al PSE. Tampoco la hubo para IU. Sin embargo, ésta no contaba en los análisis del periódico, mientras que PP y PSE constituían la alternativa al nacionalismo no sólo teórica, sino realmente posible, hasta que los resultados demostraron lo contrario. Es esta crítica al nacionalismo gobernante, que aparece a lo largo de toda la campaña, la que puede inducir al lector a concluir una mayor identificación con las opciones del PP y PSE, entendidas en conjunto, como alternativa. La llamada a la unidad democrática de los partidos, hecha después de saber los resultados electorales, venía precedida de un notable escepticismo sobre las posibilidades de evolución de la política vasca, escepticismo generado ya por las expectativas de voto, pero mucho más por las dudas que ofrecía la coalición nacionalista, es decir, el PNV, y, en concreto, su disposición a luchar contra el terrorismo.

La crítica al PNV y a algunos de sus dirigentes fue constante y dura. Si se exceptúa el editorial dedicado a la política del gobierno central, siempre está el nacionalismo de la coalición, especialmente el del PNV, en el centro de la reflexión del periódico. Aquélla destacó, en unos casos, la irresponsabilidad, la desmesura en sus pretensiones y apología de la barbarie (en tácita alusión a manifestaciones de Arzalluz); en otros, expresó la condena y fracaso de toda política orientada a crear una sociedad homogénea, como había ocurrido con el soberanismo; se opuso, como ya se ha visto, a la construcción nacional etnocéntrica de la colectividad, lo que era una manifestación de las pretensiones de homogeneización; denunció la uniformidad (la falta de moderación y respeto de la pluralidad vasca), el partidismo, el soberanismo, el etnocentrismo, la doblez, la tibieza contra el terrorismo y el silencio de sus políticos y responsables institucionales y la «estupidez canalla» (la más inmoral de las manifestaciones, según el periódico) de considerar a ETA aliada objetiva del Partido Popular. El Correo pidió a los nacionalistas más que condenas en su actitud ante la intolerancia y el terrorismo y, así mismo, renuncia a ver con normalidad la separación entre los sometidos al terror y los otros. Si a los dirigentes del PNV, en general, se les consideró culpables de omisión, de victimismo e insolidaridad, a Arzalluz, en concreto, se le censuró agriamente por su jactancia de lastimado al defender que los asesinatos perjudicaban más al PNV que a cualquier otro partido (se critica el mero hecho de hacer cuentas del efecto electoral de los asesinatos) y al no admitir que su política de Lizarra estaba en el origen del desencuentro democrático del que se valía ETA. 
Esta abundante y áspera denuncia del nacionalismo de la coalición (PNV, fundamentalmente), centrada básicamente en torno a la actitud ante ETA y ante el pluralismo político y cultural de los ciudadanos vascos, remitía a los valores de la vida, seguridad y libertades y, por ello, lógicamente, ponía en cuestión que tales objetivos definiesen en la práctica la política y la estrategia nacionalista, lo que no impidió a $E l$ Correo referirse al PNV y EA, más pensando en los lectores nacionalistas que en la lógica argumental, como el nacionalismo democrático. En este sentido cabe hablar de un rechazo tácito del voto a la coalición nacionalista. No se puede, por el contrario, decir lo mismo en cuanto a un apoyo preferente al Partido Popular o al Partido Socialista. Con muchas reservas, podría decirse que hubo un indirecto apoyo a una alternativa al nacionalismo, que no podía ser otra que la del PP y PSE juntos, que el periódico vio difícil, si no imposible, a medida que pasaba la campaña. Lo que explícitamente se dijo llamaba a los ciudadanos a votar en conciencia y según su criterio personal.

El Correo vio en los resultados electorales la confirmación de su interpretación de la realidad vasca y la coincidencia de los valores del periódico con los de la inmensa mayoría de los ciudadanos, es decir, pluralidad de la sociedad, apoyo a las instituciones, rechazo de la violencia y el terror y voto a favor de la paz y contra ETA. Todo ello llamaba a la unidad democrática ante el terror, a la terminación de la polarización partidista y a una praxis abierta y tolerante de los políticos, a sabiendas de que los resultados electorales no habían resuelto ni la gobernabilidad del país, ni la estabilidad del sistema político. Las llamadas de atención al nacionalismo para que no interpretara su victoria en el sentido de legitimación de sus pretensiones de homogeneizar a una sociedad esencialmente plural y las recomendaciones a populares y socialistas de abandonar su pretensión de desbancar al nacionalismo del poder (semejante consideración hizo el diario El Mundo al comienzo de la campaña), unidas a un futuro incierto de gobierno y de estabilidad, demostraban la comprensión de la política vasca como el desencuentro entre voluntad popular y partidos nacionalistas (el nacionalismo en su sentido estricto carecería de suficiente apoyo social y sería una pretensión forzada e inventada por las direcciones de los partidos) y entre éstos y los de ámbito general, que anunciaba un futuro difícil y sombrío para la realización de los valores de los ciudadanos. El periódico pedía un imposible: no discutir el poder al nacionalismo, a condición de que éste no hiciera política nacionalista. Era la más clara conclusión de su anuncio sobre las dificultades que tendrían la estabilidad y la gobernabilidad futuras a pesar de la fácil investidura de Ibarretxe. 
Es importante resaltar que El Correo en sus editoriales (cosa distinta fueron las colaboraciones) trató al nacionalismo vasco como un fenómeno social, político e institucional existente en la CAV y en ningún momento traspasó el límite fáctico para realizar un análisis teórico más profundo - desde valores como la igualdad, la libertad o la democracia- y más centrado en una perspectiva o marco más amplio como podía ser el europeo. Criticó y rechazó las características, objetivos (expresamente la construcción etnocéntrica de la colectividad) y estrategias del nacionalismo vasco como contrarias a la libertad e igualdad de los ciudadanos vascos, pero no fue más allá. Dio argumentos definitivos contra el nacionalismo vasco en su sentido estricto. Pero su tesis de nacionalismo sin nacionalismo tenía aires localistas y respondía a los criterios más arriba indicados, la lucha contra ETA y el respeto a una sociedad plural. Pero no ofreció argumentos contra la ideología defensora de que las fronteras políticas deben coincidir con las fronteras culturales o contra la nueva tendencia de una nación plural independiente, basadas ambas en una previa noción no democrática de nación. Esto fue un dato general de todos los periódicos críticos con el nacionalismo. Lo mismo, en sentido contrario, ocurrió en la prensa nacionalista. La consecuencia de este silencio común es la legitimidad abstracta del nacionalismo como un supuesto sin demostración ni análisis.

El Mundo dio a las elecciones una importancia trascendental por todo lo que estaba en juego, es decir, por la posibilidad de que se diese la alternancia en el poder y por las consecuencias que ello tendría ${ }^{12}$. La principal e inmediata sería la unidad de la lucha contra ETA entre los Gobiernos de Vitoria, Madrid y París, condición primera e imprescindible para el logro de la paz, para la realización de las libertades y de los derechos humanos y para la superación de la intimidación y del miedo. $\mathrm{Su}$ interpretación coincidía con la de El Correo, aunque con un desarrollo mucho más reducido, y era, a su vez, la antítesis de lo que pensaba el nacionalismo. La variación fundamental después del día 13 sería la estrategia o la actitud ante el terrorismo.

12 Los editoriales de El Mundo son: «Nunca una cita autonómica ha significado tanto para tantos», 27-4-2001 (3); «La vergüenza de Andoain», 28-4-2001 (3); «¿Por qué Ibarretxe no se atreve a debatir con Redondo?», 1-5-2001 (3); «Libertad de prensa hoy y aquí», 3-5-2001 (3); «Fantasmas del pasado», 5-5-2001 (3); «ETA rompe la baraja antes de empezar la partida», 7-5-2001 (19); «No hay mayor "bajeza moral" que la de Arzalluz», 8-5-2001 (15); «CIS: Vulneración legal y estímulo para acudir a votar», 10-5-2001 (3); «Por si faltara alguna razón para votar mañana...», 12-5-2001 (3); «Votar es un deber», 13-5-2001 (37); «Un PNV hegemónico ante el reto de administrar su victoria», 14-5-2001 (33). 
Mostró una oposición frontal contra la violencia de ETA, así como contra la violencia de Estado en el caso del GAL, y reconoció su ingenuidad por pensar que ETA no mataría en campaña para evitar el perjuicio de EH. Con el asesinato de Giménez Abad pensó que los votos de EH no le importaban. ETA y sus cómplices de EH eran la barbarie, la intolerancia, el oscurantismo y la crueldad. A pesar de que su futuro estaba en el basurero de la historia, eran el problema o, tal vez, mejor, la enfermedad de Euskadi.

El Mundo fue meridiano en su orientación del voto. Si la opción del Partido Socialista era una opción segura, la del Partido Popular era absolutamente segura. Así lo dijo expresamente. Defendió el voto a favor de un gobierno de coalición integrado por el PP y el PSE para liderar la lucha contra el terrorismo de ETA. Y lo hizo sin ningún empacho, ya que en su opinión el gobierno vasco era cuestión de dos parejas; el PP y PSE, por un lado, y el PNV-EA y EH por otro. De la misma manera, es decir, expresis verbis, consideró indeseable el voto a $\mathrm{EH}$, poco segura la opción del PNV y dudosa la de Izquierda Unida. Esta pública definición ante las opciones más importantes no debe ocultar la insistencia del periódico en la necesidad de que el lugar del PNV era la oposición.

Las recomendaciones a populares y socialistas para el logro del éxito electoral y la convicción de que sólo el PP y el PSE podían liderar desde el Gobierno vasco la lucha contra ETA se sumaron a una crítica al nacionalismo en todas sus versiones, que no deja ninguna duda sobre la orientación del voto. Las censuras al GAL con la expresa mención de la criminalidad del Estado, lo que suponía una crítica al Partido Socialista, y al gobierno del PP por su comportamiento con la encuesta del CIS - retrasar la publicación de los datos de la encuesta, supuestamente para no perjudicar al $\mathrm{PP}$ - no desviaron al periódico del objetivo de denunciar a los nacionalismos existentes. Nueve de diez editoriales lo hicieron. Esto ocurrió con la barbarie de ETA y con su brazo político o cómplices, Euskal Herritarrok, pero, quien más atención recibió fue el Partido Nacionalista, al que de manera implícita se le consideraba el problema de Euskadi y, en consecuencia, el problema electoral. Aunque no se utiliza el término, la convicción de que Euskal Herria era una entelequia, en su sentido de cosa irreal, subyace como supuesto a las manifestaciones contra el PNV. El voluntarismo político y la invención utópica de un nacionalismo soberanista, sociológicamente infundado, agravaban otras acusaciones, ya de por sí graves, como eran la amenaza que para las libertades y la convivencia constituía el nacionalismo excluyente de la coalición, el casi total abandono nacionalista de su responsabilidad ante el terrorismo, la utilización electoral de los asesinatos, la traición de Arzalluz e Ibarretxe por pactar con ETA en Lizarra, 
el ejercicio sectario del poder de gobierno, la bajeza moral de Arzalluz o su discurso nacionalista, que servía de coartada a ETA. El Mundo concluía que acercarse al PNV y pactar con él era un error, ya que nada cambiaría con el PNV en el gobierno. Su lugar era la oposición.

En cuanto a los resultados electorales, si bien consideró decepcionante el resultado para los defensores de la alternativa en el poder, a pesar de que había habido razones para confiar en el éxito, recordó que el PP había ganado en 1996 después de haber perdido por muy poco en las anteriores elecciones. Además de obtener casi 600.000 votos, populares y socialistas habían conseguido sensibilizar a la sociedad vasca frente a ETA y sus cómplices. Estos habían sido los grandes derrotados. El triunfo de la coalición nacionalista se explicaba en buena medida por esta derrota de EH.

El diario sacó excesivas consecuencias de los resultados al afirmar que se reforzaba la hegemonía del nacionalismo de la coalición o que se fortalecía a Arzalluz o que se favorecía un cierto renacimiento del nacionalismo catalán y un debilitamiento del liderazgo de Rodríguez Zapatero. Las mismas carencias teóricas sobre el nacionalismo observadas en El Correo existen, también, en El Mundo.

El meollo de las elecciones en la grave situación que vivía el País Vasco, situación de imposición y miedo, estaba en la posibilidad de que se produjera la alternancia en el poder, avalada por las encuestas y el cambio de tendencia del electorado, y que ello pudiera incidir en la lucha contra el terrorismo, ante el que el nacionalismo gobernante había fracasado, ya que ni convenció ni derrotó a ETA. Esta presentación de las elecciones hecha por El País ${ }^{13}$ se refería a los motivos por los que las elecciones vascas despertaban tanto interés en España. A partir de los primeros datos de las encuestas durante la campaña el periódico confirmó que ante el nacionalismo había una verdadera coalición que podía ser alternativa de gobierno, pero no la defendió para luchar contra el terrorismo. Como los anteriores periódicos analizados, El País asociaba la lucha contra ETA con la defensa de la libertad.

El rechazo de ETA, a la que calificó de independentista y totalitaria, fue absoluto. El diario interpretó que con su violencia quería demostrar la eficacia de la misma ante objetivos que de otra forma no se podrían alcanzar, aunque no aclaró qué objetivos. Encomendó, de prin-

13 Los editoriales de El País son: «Lo deseable y lo posible», 29-4-2001 (12); «No habrá debate», 1-5-2001 (8); «Empate», 6-5-2001 (14); «ETA nunca se fue», 7-5-2001 (10); «Sectarismo sin límite», 9-5-2001 (10); «Juego limpio», 10-5-2001 (10); «Rama ilegalizada», 11-5-2001 (12); «Votos contra el terror», 13-5-2001 (14); «Gana Ibarretxe», 14-5-2001 (10). 
cipio a fin de la campaña, a la unidad democrática, al entendimiento entre Gobierno Vasco y oposición y a una mejor relación con el gobierno central la lucha contra ETA. Los violentos requerían un programa de deslegitimación democrática y eficacia policial.

A pesar de calificar de voluntaria la ignorancia de quienes (partidos de Lizarra y, anteriormente, otros partidos y personajes públicos) afirmaban que ETA era la expresión de un conflicto político previo que requería la negociación - lo cual implícitamente suponía afirmar que con ella se acabaría ETA y que los que la rechazaban no querían su desaparición-, el remedio de la unidad democrática contra ETA era un desideratum imposible. El periódico así lo insinuó, casi lo dijo, pero no sacó sus consecuencias, que, de hacerlo, le habrían llevado a la necesidad lógica de apoyar la coalición de Mayor con Redondo, algo que, según parece, fue irrealizable. Se quedó en lo ideal, en lo mejor, en lo deseable, es decir, en la imposible unidad democrática por culpa del nacionalismo.

El País no pidió el voto para ningún partido. Había que votar según criterio personal a la formación más eficaz en la lucha contra ETA para acabar con la coacción e implantar la libertad. Explícitamente no se dijo nada más, ni a favor ni en contra de ningún partido, aunque la moderada consideración de EH como partido antisistema parecía excluirlo como destinatario del voto.

Es la crítica a los partidos la que permite descubrir que, aunque el periódico no ahorró comentarios contra el gobierno popular central en sus editoriales denunciando, por ejemplo, su sectarismo, la acusación ante lo que el periódico pensaba que era la razón de ser y la esencia de las elecciones la hizo contra el PNV y, no obstante, no sacó explícitamente ninguna conclusión contra él, sino buenos deseos y bastante escepticismo. Los argumentos contra el PNV eran: la práctica en ETB (televisión vasca) del mayor sectarismo conocido; la estrategia pasiva ante la violencia juvenil; la desautorización infundada de actuaciones judiciales contra la violencia; la tesis de que se compartían los mismos fines de ETA; el retraso de la convocatoria de las elecciones por intereses de partido; la afirmación de que la victoria del PP daría mayor justificación a ETA (Arzalluz); y la pretensión del PNV de que se aceptara su programa para establecer la unidad contra ETA.

Frente a la preferencia de los encuestados votantes del PNV, EA y PSE de que se creara un gobierno de coalición entre sus tres partidos, que parecía coincidir, según el periódico, con los planteamientos iniciales del candidato nacionalista (la intención del debate habría sido la de mantener esa posibilidad rompiendo el entendimiento entre el PP y el PSE), El País propuso el gobierno de concentración democrática entre 
nacionalistas y no nacionalistas contra ETA a sabiendas de que era poco realista. Las posibilidades de pacto entre nacionalistas y socialistas eran pocas por causa del programa soberanista de la coalición y por los votos recibidos o por recibir de Euskal Herritarrok. Una vez conocidos los resultados, éstos exigían al nacionalismo pactos transversales de gobierno o parlamentarios tanto para gobernar como para luchar contra el terrorismo y exigían, a su vez, a populares y socialistas lealtad para lograr acuerdos para la gobernabilidad. El País no renunció, según esto, a su tesis de pactos entre todos los partidos políticos considerados democráticos, que obligaba al PP y PSE a ceder en cuestiones substanciales. Para el periódico era simplemente cuestión de un equilibrio respetuoso - sin suficiente explicación - con sus compromisos electorales y con la voluntad mayoritaria de los votantes.

Deia se incorporó a tratar las elecciones en sus editoriales una vez pasada la mitad de la campaña. Esta ausencia de opinión oficial era una práctica bastante habitual en el periódico del PNV. Sus editoriales apenas trataron los temas de campaña, con lo que parecía querer transmitir una imagen de equilibrio o neutralidad, pero dejó para los artículos, notas y «breves» transmitir la opinión oficial. Semejante estrategia también podía deberse a la falta de razones para defender determinadas tesis en un escrito largo. Era mejor y más eficiente utilizar escuetos textos que actuaban como imágenes.

Interpretó las elecciones de una forma radicalmente distinta a los tres periódicos anteriores ${ }^{14}$. Puesto que la preocupación de la sociedad vasca estaba en los contenidos (vivienda, política fiscal, tren de alta velocidad...) de los programas electorales, la campaña había que utilizarla para exponer tales programas, de manera que el electorado pudiera elegir con conocimiento a quienes, desde el autogobierno, iban a gestionar los intereses más directos de los vascos. El periódico incluía el aumento de autogobierno como un posible interés más. No hacía alusión ni a la libertad, ni a la vida, ni a los requisitos para garantizarlas.

Esta afirmación de que, por ejemplo, el debate sobre la construcción del tren de alta velocidad (infraestructuras) interesaba más a la sociedad y a los votantes que el debate sobre la violencia y su incidencia sobre la vida y libertades de los ciudadanos, está en la línea de la campaña de la coalición nacionalista, que con su insistencia en el bienestar

14 Los editoriales de Deia son: «Distensión y exposición de los programas», 6-5-2001 (35); «Cohesión social frente al asesinato», 7-5-2001 (25); «Acusaciones políticas y sus consecuencias», 8-5-2001 (31); «El mitin del candidato que nadie desea», 13-5-2001 (27); «Votos para buscar una solución dialogada», 14-5-2001 (9). 
económico y en la eficacia y superioridad de los vascos narcotizaba a sus votantes para ver en todo su dramatismo la realidad de los «otros», los amenazados. Por importantes que sean otros contenidos de un programa, no hay debate más fundamental que el de la seguridad de la vida y la libertad. Ahí está la esencia de la historia de la configuración del poder político y, lógicamente, la piedra de toque del Estado.

La llamada nacionalista a la distensión no podía hacerse pidiendo el silencio de lo que llevaba al sufrimiento y, como consecuencia, a la tensión y al enfrentamiento. El silencio aumentaba el drama político y social. Ahora bien, según Deia, había que evitar las descalificaciones y recriminaciones entre partidos, aunque éstas se dieran en temas como el futuro gobierno, la violencia, la Constitución o el Estatuto.

La ausencia de análisis teóricos o simples consideraciones teóricas sobre el nacionalismo fue total y absoluta de acuerdo con el principio elemental de que lo que no tiene demostración ni justificación es mejor no tratarlo.

En la línea del planteamiento de ocultación y falseamiento de la realidad estaba su versión de la violencia. Esta no era privativa de Euskadi, ni tenía nada que ver con la utilización ideológica de la escuela pública vasca, sino con condiciones socioeconómicas, demográficas y de información globalizada. No era un problema local, sino mundial. Y, sobre todo, la violencia no era la única causa letal que de manera independiente (por ser conflicto histórico permanentemente presente) actuaba contra la sociedad vasca, cuya solución exigiría una estrategia única de todos contra ella. La violencia, que sumía a parte de la sociedad (populares y socialistas) en el miedo y la amenaza, actuaba conjuntamente con quienes - populares y socialistas - obligaban a la otra parte (nacionalistas) a convivir con la calumnia y la injusticia. La unidad era imposible. Sólo el diálogo, cuyo resultado fuera la nacionalización de todos, acabaría con la violencia. Nada de polémicas entre políticos sobre la violencia, porque aumentaban la división social. La solidaridad con las víctimas y con los que sufrían era parte de la estrategia del PNV, que se completaba con la necesidad de tener que luchar, a la vez, contra la violencia de los unos (ETA) y la calumnia de los otros (PP y PSOE).

No hubo petición expresa del voto para la coalición. Tampoco pidió el voto contra nadie, a excepción del terrorismo y esto desde la óptica nacionalista de que el problema vasco era el sometimiento de la sociedad vasca a la violencia de unos y a la calumnia de otros (populares y socialistas). Llamó a la sociedad vasca a las urnas, haciendo caso omiso del discurso de los que mataban. Pero la identificación con la campaña de la coalición nacionalista al cantar los éxitos de los vascos (de- 
porte ${ }^{15}$, economía, sanidad, formación de la juventud), criticar a los populares (partido y gobierno central) y a socialistas y jueces por su apoyo a Aznar ${ }^{16}$, defender la ideología nacionalista y los objetivos nacionalistas y coincidir con sus argumentaciones e interpretaciones políticas no deja ningún resquicio de duda sobre la orientación de su voto hacia la coalición del PNV-EA, hasta el punto de que su llamada a que los partidos discutiesen los contenidos de los programas sería un intento de evasión de una realidad política comprometedora para el nacionalismo y, a la vez, una justificación de la agresiva campaña nacionalista como respuesta a las acusaciones de los otros partidos.

La votación demostró dos cosas, según Deia: el civismo de la sociedad vasca (otro éxito más del pueblo vasco) y la necesidad del diálogo entre todos (gracias al éxito de las tesis nacionalistas), es decir, la necesidad de dialogar con el PNV, dejando los unos la violencia y los otros la confrontación. El resultado sería lo imposible: el consenso sin renunciar al programa.

Para Gara la campaña electoral era un grave peligro para el nacionalismo vasco por dos razones ${ }^{17}$. La primera, porque el nacionalis-

15 El día mundial dedicado a la libertad de prensa coincidió con la campaña electoral y mereció los editoriales de varios periódicos que, por una parte, resaltaron el vínculo indisoluble entre el derecho a la información, el progreso y la democracia, y, por otra parte, denunciaron la situación vasca de intimidación y terror, en la que se había asesinado a periodistas y se hacía difícil la libertad de información. Deia, por su parte, escribió un editorial titulado «El ciclismo vasco, en la élite mundial», que no tenía nada que ver con la libertad de prensa por su contenido, pero destacaba, con ocasión de la participación del equipo ciclista Euskaltel-Euskadi en el tour de Francia y otros éxitos vascos, «el alto nivel de nuestros deportistas, la capacidad de organización y la acertada gestión, tanto económica como deportiva, de los equipos de Euskadi en casi todas las especialidades». En plena campaña electoral respondía a la propaganda nacionalista del buen hacer y del mejor hacer de los vascos en comparación con los españoles en cualquier campo, desde la economía hasta la educación o la sanidad (Deia 3-5-2001 (31)).

16 Deia no se refirió en su editorial a la ilegalización de Haika, ni a ningún otro tema de las elecciones, sino a la bajada de los tipos de interés hecha por el Banco Central Europeo en su editorial del día 11 de mayo, «El BCE sorprende con la bajada de los tipos». Algunas reacciones del PNV a la ilegalización interpretaron el hecho como la voluntad de Garzón de ponerse al servicio de Mayor Oreja, interpretaciones que fueron seriamente criticadas por El País (editorial «Rama ilegalizada», 11-5-2001 (12)). Deia, por su parte, en un breve — «No podía esperar»— publicado en la misma página que el editorial, escribió: «La tentación — decía— era demasiado fuerte y el juez estrella Baltasar Garzón no ha podido esperar ni dos días más para ilegalizar la organización juvenil Haika. Si espera, se pasa la campaña electoral y el eco es mucho menor. La clara motivación política, según muchos, de su decisión aumenta su protagonismo. A Mayor Oreja la parece bien, oportuno» (Deia 11-5-2001 (29)).

17 Los editoriales de Gara son: «La campaña más sucia y manipulada», 26-4-2001 (9); «La impunidad de los delitos de Estado», 5-5-2001 (9); «Buscar una solución definitiva», 7-5-2001 (9); «Desplazar el centro de gravedad», 9-5-2001 (9); «Quedan muchos cimientos por poner», 12-5-2001 (7); «Mayoría abertzale, dirección abertzale», 14-5-2001 (9). 
mo español (Estado español, partidos, medios de comunicación) lo había convertido en el centro de sus ataques, tal como lo había hecho durante la precampaña, y la segunda, porque este mismo nacionalismo había cometido la osadía de considerar nacionalista al PNV, cuando en realidad no lo era. Según esto, las elecciones eran tiempos que exigían atención, cuidado y crítica para que el nacionalismo de EH no saliese perjudicado. A pesar de que los resultados electorales fueron calamitosos para $\mathrm{EH} \mathrm{y,}$ por tanto, tenían que serlo también para el nacionalismo vasco según esta argumentación, nada de ello impidió decir al periódico que el abertzalismo vasco (PNV-EA más los votos trasvasados de EH) había triunfado sobre el nacionalismo español y sus inmensos medios de comunicación.

La violencia denunciada era la de los Estados británico, alemán, francés y español (éste a través del GAL), que actuaban al margen y en contra del Derecho y con absoluta impunidad en la represión de todo lo que les interesaba. Por el contrario, la violencia de ETA requería soluciones definitivas que no fueran las aplicadas hasta el momento, sino semejantes a la que se planteó en el pacto de Lizarra.

No hacía falta pedir el voto para EH. Expresamente se pidió contra el Estado español, contra el nacionalismo español y los partidos españolistas. Esta fue la principal consigna, que no excluyó el rechazo del PNV. El apoyo a las mismas causas de EH y sus justificaciones, la identificación expresa con sus soluciones y estrategias y la común crítica a populares, socialistas, medios de comunicación españoles, asociaciones civiles (Basta Ya, Foro Ermua, AVT, Plataforma Libertad) y PNV orientaron el voto hacia Euskal Herritarrok.

Gara interpretó los resultados como una victoria abertzale, a la que debía seguir un gobierno del mismo color. No era sólo el éxito del PNV y EA, sino también de buena parte del voto nacionalista de izquierda, del voto de anteriores abstenciones y del voto del miedo a un lehendakari no nacionalista. Fue el triunfo del nacionalismo vasco sobre el español. Lizarra seguía vivo, pero, y esto resultaba sorprendente, Gara advertía a la dirección de EH de la necesidad de reflexionar sobre su partido y sobre su estrategia.

\section{Análisis de las colaboraciones: consideraciones previas y datos}

El análisis de las colaboraciones de prensa, dada su extensión, se hace en este apartado y en el siguiente. Se tienen por tales todas aquéllas que están firmadas, guardan relación con las elecciones y pertenecen a los cinco periódicos cuyos editoriales han sido ya analizados. Son aportaciones que, según los periódicos, reciben distintas denominacio- 
nes —análisis, comentarios, artículos de opinión-que, en general, aparecen en las páginas de opinión, pero, en otros casos, se publican fuera de tal sección. A ellas se suman breves, notas y pequeños comentarios, siempre firmados, cuyos contenidos son también utilizados

El total de aportaciones - desechados los textos indescifrables- es de 463, de los cuales 91, es decir, el 19,65\%, merecen el nombre de análisis por su valor descriptivo, explicativo y valorativo de alguna cuestión electoral, independientemente de la denominación que acompaña al escrito. Son lógicamente los más utilizados y citados. No son considerados tales los que constituyen pura propaganda o repetición escrita de la campaña política o abundan en el insulto o la descalificación.

Aunque el objetivo del trabajo general es el análisis de la prensa ante el nacionalismo y los partidos nacionalistas, éste y los siguientes apartados tienen en cuenta lo que se escribió sobre los demás partidos. Las razones son dos: la primera, porque un partido se define por sí mismo y por su relación e interrelación con los demás partidos; y la segunda, porque al nacionalismo se le hace más difícil llenar una campaña y la prensa de una campaña sin la constante y explícita referencia al otro, al distinto e, incluso, al «enemigo».

El Correo contiene 105 colaboraciones $(22,67 \%$ del total), de las cuales 32 son análisis $(30,47 \%)$, lo que supera el tercio del total de los mismos (35,16\%). El Mundo tiene 101 colaboraciones $(21,8 \%$ del total), con 10 análisis $(10,98 \%$ y $11,36 \%$, respectivamente). El País, 80 colaboraciones $(17,27 \%$ del total) con 33 análisis $(41,25 \%$ y $36,26,5 \%)$. Deia, 137 (29,58\% del total) con 12 análisis $(8,75 \%$ y 13,18\%). Y, por último, Gara con 40 textos (8,63\%) y 4 análisis (10\% y 4,39\%).

Los periódicos distribuyen sus colaboraciones en dos partes. La primera, que desarrollo en este apartado cuarto, incluye: $1 .^{\circ}$, la visión teórica del nacionalismo o ideología del nacionalismo, es decir, las premisas ideológicas o presupuestos teóricos del nacionalismo; $2 .^{\circ}$, la definición del problema electoral y de Euskadi a través de la interpretación de la campaña y los resultados; y $3 .^{\circ}$, la legislatura o futuro postelectoral: estrategias y alternativas ante gobierno, partidos y sociedad. La segunda parte recoge la crítica a los Partidos políticos o el análisis de su responsabilidad, que se analiza en el siguiente apartado. El estudio probará la lógica de este planteamiento para analizar la posible relación entre las premisas teóricas, la naturaleza del problema político, las políticas de la legislatura y la responsabilidad de los partidos.

La distribución que hacen los periódicos de sus colaboraciones entre esta primera parte (premisas del nacionalismo, definición del problema, políticas postelectorales) y la segunda (la crítica a los partidos en su lucha por el poder) es muy desigual, aunque en todos los casos es 
mayor la atención prestada a los Partidos políticos. Ahora bien, las diferencias son notorias y se observan en el siguiente cuadro:

\begin{tabular}{lcc}
\hline Periódico & Primera parte & Segunda parte \\
\hline El Correo & $38 \%$ & $62 \%$ \\
El Mundo & $35,64 \%$ & $64,36 \%$ \\
El País & $48,75 \%$ & $51,25 \%$ \\
Deia & $9 \%$ & $91 \%$ \\
Gara & $20 \%$ & $80 \%$ \\
\hline
\end{tabular}

\subsection{Presupuestos teóricos del nacionalismo o nacionalismo vasco}

Ilustración, democracia y nación histórica se opusieron al dogmatismo jusnaturalista predemocrático y al determinismo sociobiológico.

El Correo no ofrece ningún tipo de análisis crítico del nacionalismo ni del nacionalismo vasco, aunque sí una valoración negativa tanto del uno como del otro. En el fondo de este rechazo está la identificación del nacionalismo con lo más primario -el sentimiento-, el enfrentamiento y la ruptura de la solidaridad humana e histórica. Frente a esto ofrece análisis hechos desde la perspectiva nacionalista con aires de renovación —individualismo crítico y nación vasca plural-, que en el fondo no superan los supuestos propios del nacionalismo decimonónico, a pesar de contener algún aspecto crítico de tal nacionalismo ${ }^{18}$.

En El Mundo se expone que el nacionalismo vasco — también el nacionalismo en general- era la expresión del primitivismo, la negación de la democracia y del liberalismo, la causa de una sociedad preconstituida, un factor disfuncional o inútil en el siglo XXI, el conflicto ante otra conciencia nacional y la indefinición substancial ${ }^{19}$.

El País ofrece abundantes análisis sobre el nacionalismo vasco. Son análisis en los que sus autores, como ocurre en otros muchos ca-

18 Ver El Correo 2-5-2001 (33), «Nación y patria», Ricardo Utrilla; 6-5-2001(43), «Qué se decide el 13 de mayo», Julián Marías; 11-5-2001 (34), «Comenzamos de nuevo», Andoni Unzalu Garaigordobil; 7-5-2001 (30), «iNi hijos pródigos, ni traidores!», José Antonio Rodríguez y Xavier Barandiarán.

19 Ver El Mundo 4-5-2001 (5), «El euskera», Raúl del Pozo; 8-5-2001 (88), «Democracia y nacionalismo», Francisco Umbral; 10-5-2001 (2), «Sin salida», Gabriel Albiac; (4), «La vieja tierra de mis padres», Tristan Garel Jones; 3-5-2001 (11), «Cabezas de cartón», Fernando L. Agudin; «Estatuto y trampas», German Yanke. 
sos, extraen consecuencias para la campaña, las elecciones o la sociedad postelectoral, proponen alternativas, critican a los partidos, toman postura ante la violencia, pero, especialmente, destacan el presupuesto de tales consideraciones, que es su interpretación y valoración negativa del nacionalismo, de sus elementos - la patria, la soberanía nacional o la identidad étnica - e instrumentos de actuación. Así se entienden la presentación del patriotismo constitucional como alternativa al nacionalismo étnico o lingüístico; la consideración del nacionalismo soberanista como disfuncional - causa de la desconfianza entre los gobiernos, negación de la democracia y consolidación de ETA—; el papel instrumental de la violencia, creadora de adhesión y exclusión nacionalista por miedo y terror; la falsa contraposición nacionalista entre lo español y lo vasco y su consecuencia, el carácter artificial del «contencioso» vasco; la incompatibilidad de las premisas o postulados básicos — pueblo y derechos preconstitucionales - del nacionalismo con la democracia; $y$, en sentido contrario a todo lo anterior, la justificación de un nacionalismo remozado, que entronca, también, con un problema insatisfecho, previo a la violencia, el de identidad nacional. Desde una perspectiva crítica con la idea de nación en cuanto sujeto político absoluto propia de los nacionalismos, El País ofrece asimismo la tesis del pactismo ${ }^{20}$.

El salto atrás desde los valores de la Ilustración y la democracia se evidencia con el seguimiento de la pretendida justificación aducida por el diario nacionalista Deia. Lo habitual es el recurso a los «supuestos» o a la utilización de frases breves, términos o creencias que se repiten machaconamente. El artículo de exposición sistemática prácticamente no existe. Los comentarios y, excepcionalmente, análisis que cabe encontrar están basados en supuestos ideológicos que se dan por verdaderos, no se explicitan o, si se hace, es mediante el recurso indicado a la alusión lapidaria, ya que no hay manera académica o científica de demostración alguna de semejante sistema de creencias. El concepto antihistórico de pueblo y de identidad, por ejemplo, se expresa en la pregunta que se formula como parte de una crítica amplia a la campaña contra el nacionalismo y, en concreto, contra el euskera por las palabras de Fraga: «¿No es éste un insulto muy grave ("el euskera es una

20 Ver El País 2-5-2001 (País Vasco, 4), «Metáforas ciudadanas y patriotismo constitucional», Antonio Jiménez Pericás; 5-5-2001 (16), «El conflicto como norma», Eduardo Azurmendi; 8-5-2001 (13), «"Ex illis” y soldadesca», Luis Daniel Ispizua; 10-5-2001 (22), «Mi sueño de un País Vasco en paz», Enrique Echeburúa; 11-5-2001 (14), «Por los vivos y por los muertos», Aurelio Arteta; 9-5-2001 (12), «¿Qué conflicto?», Daniel Innerarity; 30-4-2001 (22), «Ni soberanismo, ni autonomismo: pactismo», Kepa Bilbao Gaubeka. 
lengua de museo"), no sólo a quienes la usan y están determinados a usarla en sus relaciones más íntimas, familiares y con Dios, sino también a todo un pueblo que la reconoce como signo de su identidad irrenunciable»? $?^{21}$

Según esto, resulta un tanto sorprendente encontrarse con un artículo que pretende desarrollar los fundamentos de la nación y del nacionalismo, los propios de un derecho natural reaccionario, antiliberal, antidemocrático, defensor de uno de los errores fundamentales del nacionalismo, el supuesto romántico injustificado de que el mundo está dividido en grupos nacionales y que a ellos corresponde la soberanía. En él se escribe que no había lugar para la desesperanza de las naciones sin Estado todavía cautivas de otros Estado naciones, porque la ley histórica establecía que todos los imperios y Estados-nación montados sobre guerras de agresión basados en el Derecho de conquista habían sido efímeros y pasajeros. Esto se escribía a propósito de la nación vasca, aunque no se la mencionaba. El derecho de conquista se había opuesto al proyecto creador - proyecto de derecho divino- que concibió a los pueblos como una gran familia de naciones cuyas relaciones deberían estar basadas en la justicia, en la solidaridad fraterna, en el respeto de los demás a todo lo propio «por aplicación permanente de las leyes del Derecho natural, que actúan en la conciencia del hombre como ley moral universal». La soberbia del hombre había deshecho todo el equilibrio del Derecho natural, pero la historia de la liberación de los hombres y de las naciones fundamentaba la firme esperanza para el futuro ${ }^{22}$. El futuro llegó con el triunfo electoral: «Es la hora del diálogo, claro, y la de la paz. Pero también ha llegado la hora de la plena soberanía» 23 .

Gara pasa de la fundamentación jusnaturalista de la nación y el nacionalismo a otra de tipo antropológico, incluso biológico. Aparece en un comentario que mezclaba la lingüística, la neogramática, la antropo-

21 Deia 7-5-2001 (26), «La gran mentira, el gran error», José Ramón Scheifler.

22 Deia 2-5-2001 (30), «El "derecho de conquista" y sus grandes males», José Manuel de Zabala. No tiene un gran desarrollo este escrito, pero muestra con exactitud la ideología del Derecho natural o jusnaturalismo reaccionario y predemocrático — nación natural, pueblo natural - con la que el nacionalismo vasco — y buena parte del clero- pretendía justificar sus exigencias y objetivos. Es la creencia pseudointelectual, contraria a la Ilustración, romántica y épica de nación.

${ }^{23}$ Deia 14-5-2001 (28), «La derrota de los generales», Xavier Lapitz. La identificación de la esencia vasca con el euskera aparece expresamente en Deia 5-5-2001 (33), «De nuevo, el inefable Fraga», Joselu Cereceda, donde dice que el euskera es «la raíz de nuestra esencia». 
logía y la política. Según el articulista, el euskera no pertenecía al grupo indoeuropeo; cada lengua tenía su propia forma interior y esa forma estaba en función de la visión del mundo de sus hablantes; la herencia se transmitía por aprendizaje; el mundo se veía a través del euskera. Humboldt dixit. Era científico afirmar que existía un pueblo específico, el pueblo vasco, representante de los pueblos europeos autóctonos. Bastaba con adquirir la lengua para convertirse en euskaldun. La lengua era lo determinante y la cuestión de adquirirla era un acto voluntario. «El racista, el separatista es el que no admite la diferencia». La idea uniforme de España no podía admitir la singularidad del Pueblo Vasco. El grupo vasco (euskaltzale y euskaldun), que buscaba su territorio y su autodeterminación, lo hacía por instinto biológico. No era, pues, la lucha de clases o el mercantilismo el motor de la historia, «sino un concepto evolutivo científico basado en la biología. El mito de la ciencia. Así las cosas el pueblo vasco supone un problema sociobiológico, que reclama su derecho a la vida con todos los modos de respuesta. El instinto de supervivencia, la resistencia a desaparecer, violenta o no, es consecuencia de un estímulo externo». Los vasco-españoles y franceses, al atacar la historia o ignorar la lengua, iban contra su propia diferencia y razón de ser, con lo que eran extraños en su propia tierra. La política electoral sustituía a este determinismo anticientífico con la previsión de que el interés económico apostaba por la unión del PNV con el PP y, de no ser ésta posible, del PNV con el PSOE. Ahora bien, entre el problema sociobiológico y las opciones políticas existían unos indicadores que, según la actitud que se tomase ante ellos, permitían saber si se trataba con ellas de que ganase Euskal Herria. Tales indicadores eran la autodeterminación, la lucha armada, la solidaridad, la riqueza y pobreza compartidas, la negociación, el euskera y la territorialidad ${ }^{24}$.

El fundamento biologista cede su lugar a la revolución en un comentario, que trata de explicar el abandono de la premisa revolucionaria. La proclama del nacionalismo independentista revolucionario y la denuncia moralista de su marginación y olvido estaban detrás del miedo que se denunciaba en Euskal Herria tanto en el campo sindical como en el político. El bienestar eclipsaba la explotación, que existía y que existiría, pero había miedo a luchar contra el capitalismo y el neoliberalismo salvaje, miedo a perder el bienvivir cotidiano y temor a construir una Euskal Herria libre y solidaria, democrática e igualitaria. Hacía falta un nuevo sindicalismo (que no se especificaba). En el área política el miedo lo tenía el frente del PP-PSOE ante la libre decisión soberana

24 Gara 30-4-2001 (6) «Lupus», Juan Bengoetxea Zorrilla. La creencia en la comunidad natural aparece, también, en Gara 9-5-2001 (10), «La "utilidad” de los votos», Iker Gallastegi. 
del pueblo vasco. Sólo ofrecían un estatuto devaluado, incompleto, castrado, inservible ante la evolución de la UE, y la amenaza para que todo siguiese igual. Era el unionismo. Todos lo sabían, incluso el PNV-EA, que también tenía miedo a la alternativa, a la vía de los hechos hacia la soberanía. «Demasiado bienestar inmediato en juego para avestruces al futuro». La sobrevivencia de Euskal Herria sólo se garantizaba siendo Estado, como eran Estonia o Eslovenia, ya que el autonomismo era la muerte dulce de la nación. A la izquierda había convicción, pero también contrariedad y desazón ${ }^{25}$.

\subsection{La definición del problema electoral y de Euskadi}

En síntesis puede decirse que la interpretación que elabora la prensa del problema básico del País Vasco, tal como se manifestó en la campaña, oscila entre el derecho a la igualdad y libertad de los ciudadanos y el derecho a la igualdad y libertad del pueblo.

En El Correo la calificación y valoración de la campaña (unas veces se habla de campaña, otras de elecciones), la cuestión del debate y la interpretación de los resultados electorales constituyen las cuestiones centrales de la mayoría, si no la totalidad, de los comentarios. Con respecto a la primera cuestión, se defiende su carácter desigual, interminable, inquietante, trascendental, largo, cansino, antirrégimen nacionalista, prepolítico, antitotalitario, cuasi plebiscitario, polarizado, dramático e incierto. A los términos técnicos los comentarisas añaden calificativos que de una manera expresa o tácita hablan del carácter fundacional o constituyente de las elecciones como respuesta a una situación de fractura de la sociedad política y de ausencia de derechos fundamentales. Sus causas serían el asesinato, la violencia, el Pacto de Lizarra, la dictadura, el totalitarismo y el terror de ETA. El fundamento de la responsabilidad de los partidos nacionalistas de la coalición estaba en su participación en el pacto excluyente de Lizarra, en su mitología, en su compadreo con la violencia y en su indefinición ante los votos de Euskal Herritarrok. Los comentarios acerca de los resultados no sólo hablarán de sus consecuencias y ofrecerán recomendaciones políticas, sino que expresarán la misma percepción al insistir en el miedo a la perpetuación de dos comunidades irreconciliables, en el desigual reparto del terror, en la violencia como principal problema, o en la radicalidad y confrontación. Sólo la cuestión del debate escapa parcialmente a es-

25 Gara 1-5-2001 (8), «Canguelo», Gabriel Ezkurdia Arteaga. 
tas valoraciones. Algunos textos son ajenos a este esquema por su carácter más bien técnico y no falta la visión nacionalista de la campaña que no acepta como absolutamente creíble este planteamiento del problema electoral. En total son 11 los comentarios críticos con el nacionalismo; 5 pueden considerarse neutrales por sus contenidos más bien técnicos, pero que no ocultan la grave división de la sociedad vasca; 5 censuran las estrategias y política de populares y socialistas; y 4 dan una versión nacionalista o cercana al nacionalismo, consistente en apoyar el programa de diálogo, unidad y cohesión de la coalición nacionalista, así como la estrategia de Ibarretxe de evitar el entendimiento entre el Partido Popular y el Partido Socialista, y, además, en rechazar la identificación de las elecciones con una opción radical y definitiva o por la democracia, libertad y vida - representada en los constitucionalistas - o por la dictadura, tiranía y muerte - representada por los nacionalistas ${ }^{26}$.

La calificación y estrategias de la campaña, el debate y las impresiones sobre los resultados son los puntos destacados por El Mundo. A partir de todos ellos se hace una interpretación semejante a la realizada en el anterior periódico, con la diferencia de que las concesiones al nacionalismo vasco son prácticamente inexistentes. El problema de la sociedad vasca que se debatía en las elecciones era el del terrorismo de ETA y el del colaboracionismo, responsabilidad e indiferencia del nacionalismo del PNV y EA. El problema estaba entre la libertad y la coacción, entre la igualdad y la discriminación en los derechos, entre el miedo y el terror frente a la libertad y la vida. También hay algún análisis más bien técnico de las elecciones. Los comentarios contra el nacionalismo son 11; uno es crítico con el Partido Popular; 2 son técnicos y los 8 comentarios dedicados a los resultados, si bien manejan razones objetivas en la explicación, difícilmente pueden ocultar su decepción por la derrota de los partidos popular y socialista ${ }^{27}$.

26 Ver: El Correo 27-4-2001 (34), «Oferta desigual», José María Calleja; 2-5-2001 (20), «Elecciones el domingo», Kepa Aulestia; (21), «Espejismo sindical», Tonia Etxarri; 6-52001 (42), «Cartero», José María Romera; 11-5-2001 (33), «Solución y culpa», Vicente Carrión; (34), «El 14 de mayo», José Miguel Azaola; 12-5-2001 (21), «La hora de decidir», Xavier Gurrutxaga; 11-5-2001 (22), «Los bloques», Xavier Gurrutxaga; 12-5-2001 (20), «Campaña diferente», Tonia Etxarri; 13-5-2001 (38), «¿Hablamos de justicia social?», José Ignacio Calleja; 4-2001 (36), «Dos por el precio de uno», José Luis Zubizarreta; 30-4-2001 (15), «El Paso del PNV», Tonia Etxarri; (16), «La tenaza», Xavier Gurrutxaga; 1-5-2001 (16), «Ultimos minutos», Kepa Aulestia; (19), «Debates», Xavier Gurrutxaga; 4-5-2001 (20), «El peor resultado», Kepa Aulestia; 14-5-2001 (4), «Anomalía vasca», Kepa Auletia; (29), «Gane quien gane», José Luis Zubizarreta; (30), «La ocasión», Joseba Arregi.

27 Ver: El Mundo 6-5-2001 (34), «Táctica y estrategia», Isabel San Sebastián; 10-5-2001 (8), «Niebla en el norte», Victoria Prego; 12-5-2001 (2), «Contra la reflexión», Eduardo 
Sobre los temas de campaña, sociedad civil, debate, elecciones y resultados -éstos de manera muy escasa-, El País desarrolló una notable participación que insistió de manera más sistemática en la interpretación de que, frente a un nacionalismo que buscaba la monopolización o la permanencia en el poder a costa de la fractura social y división política, estaba la necesidad de una opción democrática por la restauración de la unidad política y la integración social. La campaña y las elecciones manifestaban el desgarro social y político, el miedo, la indefensión, la limitación de la libertad y la dualidad de estrategias. La línea dominante de las colaboraciones argumentó — partiendo de la fundamental culpabilidad de ETA - que la pérdida de votos y poder nacionalista desde la década de los 80 , la defensa de intereses y canonjías, el nacionalismo étnico totalitario, la irracionalidad en la forma de gobernar de los nacionalistas, la utilización ventajista del final de ETA y las posibles connivencias con terroristas y afines explicaban las características de la ruptura del pacto político y la responsabilidad del Partido Nacionalista. No obstante, no hubo unanimidad al respecto, aunque la disidencia fue mínima. Algunos comentaristas defendieron, también, que la radicalidad de la campaña no fue patrimonio de nadie, si bien los datos esgrimidos mostraban una notable diferencia. En este panorama de polarizaciones políticas y electorales no tenía cabida la afirmación de que el Partido Socialista era el único que se había quedado al margen de semejante planteamiento, es decir, en el centro del sistema, tal como se defendió de una manera sorprendente ${ }^{28}$. Junto a 9 textos técnicos, hay 7 claramente críticos con el nacionalismo, uno es pro socialista y otro pro nacionalista ${ }^{29}$.

Mendicutti; 2-5-2001 (2), «Ahora les toca a ustedes», Victoria Prego; 30-4-2001 (8), «Una oferta envenenada», Victoria Prego; (9), «Una mesa, cuatro sillas», Fernando L. Agudin; «Ibarretxe, el temeroso», German Yanke; 1-5-2001 (8), «Trampa desactivada», Victoria Prego; (9), «El cazador cazado», Fernando L. Agudin; «Sobre dioses y tumbas», German Yanke; 2-5-2001 (14), «¿Trampa o hipoteca?», Mariano Ferrer. En El Mundo 14-5-2001 (3), «iQué éxito, qué fracaso!», Victoria Prego; (8), «El cinturón de hierro», Fernando L. Agudin; (9), «El mayor desencanto», German Yanke; (10), «El fracaso de Nicolás», Montse Ramírez; (12), «Un mensaje para ETA», Carlos Etxeberri; (16), «Ibarretxe. El éxito de la tenacidad frente a las adversidades», Enrique Santarén; «Mayor Oreja. El fracaso del órdago más arriesgado», Fernando Garea; (18), «El voto útil da una victoria histórica al PNV», Casimiro García-Abadillo; (32), «Adiós, Euskadi», Gabriel Albiac; (32), «Una sociedad dividida», Juan Francisco Martín Seco; (34), «Soberanismo por vía pacífica», Fernando Onega.

28 Ver El País 8-5-2001 (18), «Polarización o moderación», Francisco José Llera Ramo.

29 Ver: El País 1-5-2001 (14), «Continuidad o cambio», Francisco José Llera Ramo; 30-4-2001 (24), «La línea de quiebra», Emilio Alfaro; 5-5-2001 (13), «Unas elecciones tristes», Soledad Gallego-Díaz; 7-5-2001 (16, País Vasco), «Apocalipsis, orain», Antón 
La versión de Deia de que la campaña era una inmensa plataforma de desvergüenza donde concurrían contra el nacionalismo vasco no sólo los partidos de la oposición, sino todos los medios de comunicación dependientes del gobierno popular más otros medios, nacionales e internacionales, e intelectuales identificados con el nacionalismo español, ya se recoge en otros apartados, especialmente en el quinto, cuando se analiza la crítica de la prensa nacionalista a los partidos de oposición. Ahora se trata de resaltar que, según los comentaristas de la prensa nacionalista, tal maniobra, por un lado, alteró la esencia y razón de ser de las elecciones - la discusión de los proyectos sobre bienes y servicios de los ciudadanos, coincidiendo así la campaña de la coalición, la línea editorial y los comentarios- y, por otro, exageró y falsificó la realidad política y social en materia de derechos fundamentales —régimen de terror hitleriano o estalinista— e hizo, además, culpables de tal situación distorsionada a los partidos de la coalición nacionalista y no sólo a ETA. La consecuencia que denunciaban los comentarios era que a través de las elecciones se presentaba al nacionalismo como el problema de Euskadi.

La interpretación de la naturaleza de la campaña como debate público de los proyectos de administración de las cosas servía, en mi opinión, para silenciar el problema básico de riesgo de destrucción de la vida política y civil y las posibles responsabilidades del nacionalismo, si bien no era la única forma de evitar el reconocimiento preciso de la realidad. La violencia de ETA era tan evidente que no permitía ser tratada como una invención de la oposición; ahora bien, sus consecuencias y efectos, alcance social y personal, explicación, responsabilidad y estrategia ante ella podían ser presentados como una exageración, desfiguración, mentira o instrumentación interesada del problema hecha por los partidos y divulgada por los medios de comunicación contrarios al nacionalismo con el fin de derrotarlo y destruirlo, objetivo que se constituiría según la prensa nacionalista en el verdadero problema de la campaña.

Urrosolo; 5-5-2001 (19), «Diez interrogantes vascos», Javier Tusell; (20), «De certezas y supuestos», Javier Ugarte Tellería; (6, País Vasco), «Tres apuntes de campaña», Ignacio Latierro; 1-5-2001 (15), «Las encuestas de la confusión», Soledad Gallego-Díaz; 12-5-2001 (8, País Vasco), «Catálogo de inconveniencias», Pedro Ugarte; 27-4-2001 (15), «Nada escapa al encono», Soledad Gallego-Díaz; 30-4-2001 (14), «Un cara a cara que nace en la división y el miedo», Soledad Gallego-Díaz; 2-5-2001 (14), «Olvidar el cara a cara», Soledad Gallego Díaz; 27-4-2001 (21), «¿Unos comicios inservibles?», Emilio Alfaro; 10-5-2001 (13.16), «Los "shock” de la noche del día 13», Soledad Gallego-Díaz; 10-5-2001 (20), «Territorios o territorio», Fancisco José Llera Ramo; 14-5-2001 (28), «A pie de urna», Javier Pradera. 
En cambio, según los comentarios de Deia, la realidad descubría que, frente a la perversión de basar la campaña y las elecciones en la necesidad de recuperar la libertad y las seguridad para todos, lo que estaba en juego era la opción entre «soberanismo» o «sucursalismo», democracia o involución, diálogo o represión policial, moderación o polarización. En otras palabras, la opción era entre «el nacionalismo vasco» y el «antinacionalismo» ${ }^{30}$.

Esta interpretación está presente y confirmada en numerosas colaboraciones, en las que las afirmaciones, hechas de manera concisa, son soportes de una argumentación dirigida, a veces, a justificar los objetivos de la coalición nacionalista y, en general, a deslegitimar la campaña de los partidos constitucionales. Tales expresiones y frases, dichas, incluso, por autores no nacionalistas en sus comentarios, expresan distintas versiones de los ataques y persecución de que era objeto el pueblo natural vasco y su servidor, el nacionalismo, principalmente el del PNV. Estas eran las versiones de la naturaleza del problema que la campaña ponía al descubierto: la lucha contra la libertad de un pueblo; la inculpación de la existencia y permanencia de ETA al nacionalismo; la criminalización del nacionalismo democrático; la condena del nacionalismo democrático; la violación de las leyes naturales y divinas sobre la nación; la destrucción de la cultura vasca por el españolismo; el fascismo español contra y para Euskadi; la negación de la nación vasca en nombre de la española; la resistencia de la nación vasca contra la reconquista española; la unión del nacionalismo con la violencia; el conflicto político vasco independiente del terrorismo; la construcción o aplastamiento de Euskal Herria; la aniquilación política del nacionalismo; la desaparición del nacionalismo vasco democrático; el nacionalismo, principio y fin de todos los males, incluido el terrorismo; la destrucción de las ideas nacionalistas; y la soberanía usurpada. ${ }^{31}$

30 Deia 7-5-2001 (26), «La gran mentira, el gran error», José Ramón Scheifler, artículo que recogía la propaganda del PNV; Deia 12-5-2001 (29), «Un debate clarificador», José Ignacio Bajo; Deia 12-5-2001 (26), «Apuntes para una reflexión», Amaia Fano; Deia 11-5-2001 (17), «13 M, lo que es y no es», Mariano Ferrer, Pedro Ibarra, Ramón Zallo, comentario que era, en realidad, un penoso escrito propagandístisco a favor de la coalición nacionalista.

31 Ver Deia 30-4-2001 (16), «Los jinetes de Kazán», Antonio Alvarez Solís; «Hablad, hablad, hablad», Enrique Curiel; (22), «La división acorazada», Joaquín Leguina; 1-5-2001 (30), «Los obispos y la paz», José Ramón Scheifler; 2-5-2001 (30), «El derecho de conquista y sus grandes males», José Manuel Zabala; 3-5-2001 (11), «Fraga arremete contra el euskera, Mayor Oreja calla», J.C. Ibarra; (32), «Los amigos italianos de Aznar», Kepa Bordegarai; 4-5-2001 (10), «La credencia vasca», Joaquín Navarro; 5-5-2001 (11), «Elecciones en la CAV en la época del postLizarra», Milagros Rubio; 6-5-2001 (36), «Dime quién te aplaude y te diré quién eres», Iñaki Anasagasti; 7-5-2001 (26), «La gran mentira, 
Sobre el debate, salvo los apoyos de rigor a favor de Ibarretxe y los latiguillos hirientes contra Mayor y Redondo, todos ellos escritos sin ningún tipo de desarrollo, no hay nada que aportar. Los resultados -opinión unánime - daban la razón a la estrategia del diálogo. No hubo en la prensa nacionalista concesión alguna a voces favorables a populares o socialistas.

Este periódico interpretó los datos electorales como el triunfo de la opción nacionalista, cuyo mensaje electoral había estado centrado en el diálogo. El electorado hacía suyo lo más esencial del programa nacionalista. Un coro de voces, casi al unísono, repitió lo que se decía en titulares en la primera página, que el diálogo había ganado las elecciones. Los propagandistas de la coalición confirmaban con los datos las claves de la campaña.

Era, así, el momento de sentarse a hablar. Lo más urgente era dialogar, es decir, hacer lo que algunos no habían querido, dialogar para gobernar, para buscar soluciones, frenar a los violentos, conseguir la paz, la libertad y la esperanza para la sociedad.

La victoria había sido para el nacionalismo «democrático» y el diálogo, mientras que el fracaso lo había sido para la estrategia de acoso e incomunicación del PP, seguido por el PSE, los medios de comunicación y la tergiversación del mensaje nacionalista. El gobierno de Aznar había tenido buenos motivos para silenciar los datos de la encuesta del CIS.

Se había derrotado a los generales como Mayor, Redondo y ETA. Era la hora del diálogo y de la paz, pero, también, de la plena soberanía.

Los resultados habían demostrado el error de creer que lo bueno para un español era lo bueno para un vasco. Al Partido Popular no le habían valido ni el voto por correo, ni las encuestas maquilladas, ni los empadronamientos en naves industriales, ni el modelo alavés. La victoria había sido para el diálogo en una votación en libertad. Con ello se había demostrado que era mentira que no se podía votar en libertad ${ }^{32}$.

el gran error», José Ramón Scheifler; 9-5-2001 (32), «El 13 de mayo, elección», Luis M. ${ }^{a}$ Retolaza y Ramón Labaien; 12-5-2001 (26), «Apuntes para una reflexión», Amaia Fano; (29), «Un debate clarificador», José Ignacio Bajo; (30), «Reduccionismo irresponsable», Vicent Franch; «Al copo», Xavier de Antoñana. Algunos comentarios ya citados en otros lugares hablan de la violencia como principal problema, pero sin separarlo de esta matriz de interpretación o con una notable ingenuidad. El artículo de Alfonso Arnau Tornos, «iSalvar los muebles?», Deia 30-4-2001 (7), sobre las identidades del pueblo anfitrión, el vasco, y el pueblo huésped, el español, parece tener buenas intenciones, pero es un disparate de principio a fin.

32 Ver Deia 14-5-2001 (1), «El diálogo gana las elecciones»; (2), «Ha ganado el diálogo, es tiempo de sentarse», Juan José Baños; (3), «Rotunda victoria», J.C. Ibarra; (28), «CIS-EN inkesta ezkuntuak asmatu», Amatiño; «La derrota de los generales», Xavier Lapitz; «Ni hoy ni nunca, así no es posible», Amaia Fano; (30), «Lo que nos une y lo que nos separa», José Ramón Scheifler. 
Las colaboraciones sistemáticas sobre los temas de este apartado no existieron en Gara, salvo la que explicó el adelanto de las elecciones. El debate y los resultados pasaron desapercibidos para los comentaristas, a excepción de breves y aisladas alusiones. Sin embargo, artículos, cuyo tema central no era la interpretación de la campaña, daban una versión de la misma que de forma meridiana permitía ver la manera de entender el problema vasco, el del derecho a la vida y libertad de un pueblo. La misma explicación del adelanto del fin de la legislatura servía para aclararlo.

Las elecciones fueron la consecuencia de la decisión unilateral de Ibarretxe de romper el acuerdo parlamentario de PNV/EA con Euskal Herritarrok a raíz de los asesinatos de Pedro Antonio Blanco y Fernando Buesa $^{33}$. Y lo que pusieron en evidencia fue que lo que estaba en juego era el derecho a la vida de un pueblo, el pueblo vasco. Todo, desde el ataque a los partidos políticos hasta la petición del voto, estaba basado en criterios relacionados con esta inicial premisa. Así la sobrevivencia de Euskal Herria que exigía la formación del Estado vasco; la estrategia española de destrucción del proceso democrático de construcción nacional; el nacionalismo español contra el vasco; la negación del hecho nacional y lingüístico vasco; la desvasquización y españolización del pueblo vasco; el riesgo de desaparición de la nación vasca; la agresión político-mediático-intelectual contra la realidad nacional vasca; la soberanía vasca; la desaparición del pueblo vasco; y la ausencia de soberanía como explicación de la falta de paz. Lo mismo que definía el problema electoral y de la campaña, definía el problema de la sociedad vasca. También se dijo, aunque fue una excepción, que el problema era el de una Euskal Herria libre y solidaria contra el capitalismo y el neoliberalismo salvaje. ${ }^{34}$

Los resultados demostraron que la estrategia de Madrid había fracasado, quizá para siempre. Pero no sólo eso: los que sin pasar por las urnas habían querido no sólo intervenir, sino mandar en la política de Euskadi, tenían la oportunidad para hacer una profunda reflexión. ${ }^{35}$

33 Gara 27-4-2001 (12 y 13), «La campaña electoral culmina el proceso iniciado con la ruptura del acuerdo de PNV y EA con EH», Carlos Dronda.

34 Ver Gara 30-4-2001 (6), «Lupus», Juan Bengoetxea Zorrilla; 1-5-2001 (8), «Canguelo», Gabriel Ezkurdia Arteaga; 2-5-2001 (11), «Su libertad y su canibalismo», Iñaki Gil de San Vicente; 6-5-2001 (11), «Sarcasmos», Javier Salutregi Mentxaka; 8-5-2001 (8), «¿Alguien quiere mentira mejor?», Txotxe Andueza; 9-5-2001 (10), «La "utilidad" de los votos», Iker Gallastegi; 10-5-2001 (10), «Un voto para la soberanía y la paz», Rafa Díez, Itziar Lopategi, Ainoa Extaide; 11-5-2001 (10), «Gazteok, indarra eta borroka», Gari Mujika; 12-5-2001 (8), «País Vasco-Español versus Euskal Herria», Xarlo Etxezaharreta.

35 Gara 14-5-2001 (8), «Ezertarako balio izan ote dute?», Mikel Aramendi. El texto en euskera dice: «Madrilen estrategiak porrot egindu, behar bada betirako. Baina ez hark ba- 


\subsection{La legislatura o futuro postelectoral}

El «después» de las elecciones era o bien una cuestión de formación de Gobierno con sus diversas alternativas y objetivos según periódicos y analistas o algo más profundo, que, además de incluir la formación del gobierno, exigía la reconstrucción moral de la sociedad vasca, la modernización ilustrada del nacionalismo y la restauración universal de la condición de ciudadanos.

Las consideraciones en El Correo sobre lo necesario y conveniente para la siguiente legislatura dependían de la definición previa de la naturaleza del problema fundamental de Euskadi, el cual, a su vez, era deudor de unas premisas teóricas. Algunas aportaciones responden a un nacionalismo que ve en la inexistencia de la nación vasca y en su creación el alfa y el omega del problema. La construcción nacional disolvería lo que otros consideraban el origen del problema, la violencia. Su visión del futuro iba unida a propuestas de liderazgo nacionalista.

La mayoría de los comentarios - sin entrar en la cuestión de si el nacionalismo era el fundamento ideológico de la violencia (más bien, cuando se alude, se dice lo contrario) - optaron por una interpretación explícita o implícita de que la ausencia de libertad y de paz, fruto de la violencia, era el problema, cuya solución requería la ruptura del PNV y EA con el mundo radical, su unión a los demás grupos democráticos y el abandono de cuanto le impedía tal unidad.

Según esto, los comentarios abundaron en torno al posible entendimiento entre la coalición y EH —el problema de la aceptación o no de los votos de $\mathrm{EH}-$, es decir, el frente nacionalista, que fue rechazado como lo fue, también, el frente constitucionalista, la llamada alternancia de populares y socialistas. Con respecto al primero dejaron ver serias dudas sobre las intenciones reales del PNV y manifestaron más que alguna certeza sobre su incapacidad de cambio. Con respecto al segundo, las expectativas de desaparición o reducción de la autonomía y su contradicción con la construcción de una sociedad diferente y autogobernada fundamentaron su exclusión, aunque no la posible conveniencia de su presencia transitoria en el poder para demostrar su inutilidad.

Esto supuesto, quedaba el liderazgo nacionalista de la unidad democrática por la construcción nacional —una especie de ensueño metafísico o justificación de afiliaciones nacionalistas - y la solución ideal, aunque poco real, la llamada transversal — que, dicho sea de paso, sólo

karrik: hautestontzietatik pasatu gabe euskal politikagintzan esku hartu ezezik agindu nahi izan dutenek gogoeta sakona egiteko aukera dute». 
tenía en cuenta la variable nacional- Esta fue la más defendida, con matices distintos, particularmente en la recta final de la campaña y, más bien, por plumas nacionalistas o afines al nacionalismo, cosa que no ocurriría de forma sistemática en el periódico Deia. En el rechazo de un gobierno popular con los socialistas y en la defensa del gobierno transversal la crítica recayó sobre el Partido Popular. Frente a un comentario claramente pro nacionalista hay nueve críticos con el nacionalismo. A pesar de que la estrategia política postelectoral fue tratada en términos de formación de gobierno, no faltaron otras consideraciones, especialmente sobre la banalidad del mal y la modernización en Euskadi, que constituían una durísima censura al nacionalismo ${ }^{36}$.

Para el periódico El Mundo la legislatura era una cuestión de Gobierno y, como todos los comentarios a que ahora me refiero se hicieron antes de conocerse los resultados, las consideraciones, análisis, propuestas y valoraciones partían de las manifestaciones y proyectos de los partidos, de los sondeos o de los problemas, objetivos e interrogantes que el propio comentarista planteaba. Cuatro comentarios son beligerantes contra el nacionalismo y lo excluyen del gobierno expresa o tácitamente, lo cual era un apoyo a la alternancia en el gobierno. Ninguno es pro nacionalista; varios son más bien técnicos y neutrales; y un comentario en defensa de la transversalidad es anecdótico e ingenuo. La dificultad o imposibilidad de un gobierno estable; la mejor posición de la coalición nacionalista para gobernar en minoría; el rechazo de los votos de $\mathrm{EH}$; y los distintos gobiernos posibles y sus justificaciones fueron los temas básicos, donde destaca el escrito que atribuye al socialismo y a Redondo el desvelamiento de la falsedad de los argumentos del PNV. El tema ya había sido tratado en este mismo periódico ${ }^{37}$.

36 Ver: El Correo 3-5-2001 (18), «Ni más ni menos», Kepa Aulestia; (19), «¿Qué significa esto?»; Santiago González; (20), «Otra cosa», Tonia Etxarri; 9-5-2001 (19), «Decidirse», Kepa Aulelstia; (20), «Sartén o fuego», Santiago González; 10-5-2001 (19), «El ausente presente», Kepa Aulestia; (20), «Lo malo conocido», Tonia Etxarri; (21), «Incógnitas», Xavier Gurrutxaga; 4-5-2001 (36), «Dos por el precio de uno», José Luis Zubizarreta; 29-4-2001 (40), «Transitar», José Luis Zubizarreta; 5-5-2001 (32), «Navarra como laboratorio», Gregorio Monreal Zia; «Una apuesta para el futuro», Patxi Ormazabal e Inaxio Oliveri; 6-5-2001 (36), «Pluralidad e integración», Xavier Gurrutxaga; 12-5-2001 (29); «Aprender del pasado», Andoni Pérez Ayala; 9-5-2001 (35), «Después de las encuestas», Javier Elzo; 12-5-2001 (28), «Dosificar la esperanza», Agustín Domingo Moratalla.

37 Ver: El Mundo 28-4-2001 (13), «Problemas en la "pol position”», Mariano Ferrer; 4-5-2001 (6), «Las matemáticas no son democráticas», David Barbero; (9), «El sereno», Fernando L. Agudin; «El día de Ibarretxe», German Yanke; 9-5-2001 (8), «De pactos e intoxicaciones», Victoria Prego; (9), «La ecuación armada», Fernando L. Agudin; «El pro- 
También en El País la mayoría de los comentarios enfocaron el futuro de Euskadi como una cuestión de gobierno, que debía enfrentarse con el problema principal de la sociedad vasca, definido, según los casos, como terror, nacionalsocialismo, sociedad incivil, falta de libertad o ETA. La opinión mayoritaria encomendaba tal misión a gobiernos sin nacionalistas, no por principio, sino por la orientación actual del PNV. Puede decirse que la cuestión que absorbe a la mayor y mejor parte de los análisis es la explicación de la imposibilidad del gobierno ideal de integración de los partidos democráticos, ya que no tenía cabida en él un PNV responsable de la situación de la sociedad vasca por su impotencia, colaboración, alianzas, complicidades y simpatías con los radicales abertzales, responsabilidad que no sería asumida más que con la exclusión del poder. Sólo quien interpretaba el problema de la sociedad vasca en los términos de la campaña nacionalista de la coalición ofrecía una alternativa distinta. De forma mayoritaria, pues, este periódico presentaba la legislatura en términos de restauración universal de la condición de ciudadanos para todos los miembros de la comunidad vasca. Hubo comentarios que simplemente analizaron las posibilidades de distintas alternativas de gobierno, sin entrar en una valoración de las mismas. Alguno insistió más en la necesidad de recuperar la unidad de los demócratas que en los posibles gobiernos ${ }^{38}$.

Esta cuestión no aparece analizada en el diario nacionalista Deia por los habituales comentaristas. Basta recordar que el futuro se anunció como el tiempo del gobierno para el diálogo, tal y como más arriba se ha recogido, lo cual suponía el apoyo al gobierno nacionalista, como era lógico. Lo mismo cabe decir sobre un gobierno nacionalista sin $\mathrm{EH}^{39}$.

yecto de EH», German Yanke; (16), «Voto sin anestesia», Mariano Ferrer; 8-5-2001 (8), «Banderas de conveniencia», Casimiro García-Abadillo.

38 Ver: El País 27-4-2001 (15), «Nada escapa al encono», Soledad Gallego-Díaz; (23), «Euskadi, recta final»; 10-5-2001 (11 y 12), «La hora de Euskadi», Antonio Elorza; 29-4-2001 (18), «Por la libertad y contra el miedo», Fernando Savater; 30-4-2001 (19), «Reconstrucción», Enrique Gil Calvo; 7-5-2001 (11), «La bici con las dos manos, ya», Mikel Azurmendi; 9-5-2001 (8, País Vasco), «Entre el nacionalismo y la libertad», Ainhoa Peñaflorida; (20), «Lo soñé», Juan Carlos Rodríguez Ibarra; 13-5-2001 (22), «Alternancia y concentración», Francisco José Llera Ramo; 3-5-2001 (19), «El PP se lo juega todo a la alianza con el PSE», Luis R. Aizpiolea; (22), «Estrategia y lealtades»; Joseph Ramoneda; 9-5-2001 (15), «Los electores vascos juegan a los dados», Javier Pradera; 30-4-2001 (24), «Aquel 13 de mayo de 2001...», Koldo Unceta; 8-5-2001 (22), «O algo así», Emilio Alfaro; 11-5-2001 (13), «13 de mayo», Felipe González; 13-5-2001 (País Vasco, 6), «Aritmética electoral y escenario postelectoral», Andoni Pérez Ayala.

39 Para J.C. Ibarra la campaña había clarificado que PNV-EA no se apoyaría en los votos de EH, mientras que PP y PSE, además de apoyarse mutuamente, se permitirían «coin- 
Por supuesto que no hubo ningún apoyo a un gobierno de PP y PSE. Sin embargo, en Deia se aludió de manera incidental a los gobiernos mixtos o de concentración. Lo hicieron autores nacionalistas y no nacionalistas en comentarios, cuyo centro de interés era otra materia. Por ello, tales apreciaciones fueron escritas, en general, después del atentado de la campaña. Pacto de socialistas con PNV y EA; Gobiernos mixtos o de concentración para la tarea principal de acabar con la violencia; rechazo del frentismo; soluciones transversales y diálogo general con todas las fuerzas políticas que condenasen la violencia; reconocimiento de que la mayoría social estaba a favor de los gobiernos mixtos o a favor de un gobierno nacionalista solo o con IU, pero sin $\mathrm{EH}$; y consensos entre los partidos contrarios a la violencia fueron las expresiones utilizadas, la mayoría de las cuales pretendía justificar, fundamentalmente, el rechazo de un gobierno constitucional popular y socialista. $^{40}$

La afirmación del editorial de Gara de que el gobierno debía ser un gobierno abertzale conforme con el éxito abertzale de los resultados no tuvo ningún desarrollo analítico en los comentaristas, salvo la resignada llamada a la izquierda aberztale al compromiso y al trabajo por una Euskal Herria libre. EH era el único motor hacia la liberación, ya que el PNV no actuaría en consonancia con los votos radicales recibidos. ${ }^{41}$

cidir» con EH (Deia 12-5-2001 (9), «La elección es sencilla, pese a lo complejo del panorama»). Sobre este punto, el de los votos de EH, Amaia Fano escribió que la solicitud de renuncia al apoyo de EH era «la última ocurrencia del frente españolista», que podía ser discutida en el caso de que se modificase el número de la mayoría absoluta, porque, de lo contrario, alguien (el Partido Popular y el PSE), para quien el caso era gobernar como fuese, estaría jugando con ventaja. De todos modos, EH era muy libre de dar sus votos a quien quisiese; eran votos - no de ETA, como decían el PP y PSE- de igual valor, porque todavía no se había podido demostrar que ETA y EH fueran la misma cosa y, además, la aceptación o no de los votos pertenecía «al terreno de la especulación ética» (Deia 10-5-2001 (26), «Los votos de la discordia»).

${ }^{40}$ Ver Deia 1-5-2001 (18), «Muchas claves, unas elecciones», Salvador Cardús; 8-5-2001 (16), «Que se vayan», Joaquín Navarro Esteban; (17), «ETA intenta marcar el ritmo», José Luis Uriz Iglesias; (18), «ETA no quiere puentes», Enrique Curiel; 10-5-2001(2), «La palabra, la intención y los intérpretes», Juan José Baños Loinaz; (26), «Los votos de la discordia», Amaia Fano; 11-5-2001 (17), «13 M: Lo que es y no es», Mariano Ferrer, Pedro Ibarra y Ramón Zallo; (31), «El día después», Mikel Urkiola García»; 12-5-2001 (9), «La elección es sencilla, pese a lo complejo del panorama», J.C. Ibarra; (26), «Un rápido resumen de mensajes», Xavier Lapitz; «Apuntes para una reflexión», Amaia Fano;

${ }^{41}$ Gara 14.5.2001 (8), «Sigamos dirigiendo el camino», Alizia Stürtze. 


\section{La opinión de la prensa: Las colaboraciones ante los partidos políticos}

La fijación sobre el nacionalismo fue tan grande en $\mathrm{El}$ Correo que únicamente el 18,96\% de los comentarios sobre los partidos recayó sobre el Partido Popular, Partido Socialista y organizaciones que los apoyaron. Al PP se le pidió elaborar un proyecto autónomo para Euskadi, sin sometimiento a objetivos superiores, dejar de ver en el nacionalismo de la coalición al «alimentador» ideológico y político de ETA y no chantajear al PSOE con el tema vasco. Al PSOE se le exigió que superara su alternativa histórica de subordinación o al nacionalismo o al antinacionalismo. A Basta Ya se le reconoció su lucha por la libertad y el protagonismo de la sociedad no nacionalista. Se explicaron las razones (constitucionalistas y nacionalistas) del entendimiento entre PSE y PP; se cuestionó la alternativa del PP por la levedad del cambio; se defendió el euskera ante las palabras de Fraga; se criticó al gobierno del PP por la ocultación de la encuesta del CIS y se pidió veladamente el voto para populares y socialistas ${ }^{42}$.

El 62\% de lo escrito en El Correo sobre los partidos se centró sobre la coalición nacionalista. Los comentarios hablan del cansancio con el que llegó la coalición a las elecciones, en las que el nacionalismo se encontraba ante su mayor envite desde la transición. Y hablan también de una cierta división observada en el PNV con ocasión de la ausencia de Ardanza en la reunión de Ibarretxe con los exconsejeros del Gobierno Vasco y del aire de perdedor y de derrota que dejaba traslucir el PNV. Al margen de estas apreciaciones anecdóticas y discutibles, la denuncia y la crítica contra el PNV fue lo predominante en los comentarios, algunos de ellos salidos de plumas nacionalistas. Contenidos de esta denuncia fueron la ignorancia histórica que demostraba Ibarretxe al preguntarse por qué el Gobierno no pedía perdón por el bombardeo de Gernika; la petición de que aceptara de una vez el pluralismo como algo constitutivo de la sociedad vasca, que había que enriquecer en lu-

42 Ver: El Correo 29-4-2001 (34), «La hora de las preguntas», Xavier Gurrutxaga; 5-5-2001 (24), «Y en esto llegó Odón», Tonia Etxarri; (22), «El cambio», Kepa Aulestia; 12-5-2001 (18), «El Puente», Kepa Aulestia; 13-5-2001 (39), «Y entonces dijo Fraga», Henrike Knörr; (40), «La senda del resentimiento», Arramun Osa. El Correo 13-5-2001 (39), «Y entonces dijo Fraga», Henrike Knörr; (40), «La senda del resentimiento», Erramun Osa. Puede también consultarse El Correo 27-4-2001 (25), «Carta electoral», Xavier Gurrutxaga; 29-4-2001 (25), «La vuelta de Mikel», Tonia Etxarri; 5-5-2001 (23), «Menos amantes y más hablantes», Xavier Gurrutxaga; 6-5-2001 (44), «Aciertos y desaciertos», Fernando Maura; 10-5-2001 (28), «Veladuras», Santiago González; 12-5-2001 (22), «Una jornada particular», Santiago González. 
gar de eliminar; la utilización del argumento malicioso de que ETA quería el triunfo de Mayor Oreja; la indiferencia y contradicciones ante el terrorismo; la ausencia de explicación del descenso de Euskadi en el PIB español — del 9\% al 6\% entre 1975 y 2001- en oposición a la propaganda nacionalista del éxito económico; la atribución tácita a Ibarretxe de una cierta insubstancialidad, además de falta de memoria y credibilidad, mentiras y errores; la acusación de que era el PNV el culpable de la ruptura de los consensos anteriores a Lizarra y de la separación entre nacionalistas y los demás; la negación de la necesidad del nacionalismo como lo probaba el caso de Alava; la propaganda de sumisión y gregarismo nacionalista; el desconocimiento de la realidad que expresaba la ilusión en la tregua; la ingenuidad demostrada por el PNV ante el cinismo de Euskal Herritarrok; la condescendencia de Felipe González ante el PNV; la poca fe de Balza en la vía policial contra el terrorismo; la incapacidad del gobierno nacionalista de sacar el país adelante y su no siempre prioritario compromiso por la libertad; y, por último, los recelos no resueltos por la posibilidad de sumar los escaños de $\mathrm{EH}^{43}$.

Los análisis de El Correo dan una imagen penosa del nacionalismo del PNV. Algunos partieron en sus comentarios de determinados elementos de la campaña de la coalición; otros, de los años inmediatos, los del Pacto de Lizarra («apoteosis de estado de delirio»), y los más críticos hicieron historia y presentaron al nacionalismo del momento no como una excepción, sino como una lógica continuación y consecuencia de lo que fue desde sus orígenes: idea excluyente de etnicidad y lengua, falsa interpretación de la historia, simplismo nacionalista, incomprensión del proceso de industrialización, nacionalismo primordialista, esencialista y etnicista, siempre con el riesgo de exclusivismo y xenofobia. Los rasgos de esta descripción del nacionalismo del PNV, que aquí se expone siguiendo el orden cronológico de aparición en la

43 Ver El Correo 27-4-2001 (20), «El cansancio», Kepa Aulestia; (22), «La incertidumbre de Arzalluz», Tonia Etxarri; (24), «Con perdón», Santiago González; (25), «Carta electoral», Javier Gurrutxaga; 28-4-2001 (18), «El candidato de ETA», Kepa Aulestia; (20), «Sangre de horchata», Tonia Etxarri; 29-4-2001(28), «Habrá un debate», Santiago González; 30-4-2001 (18), «Una alternancia tranquila», F. Góngora; (20), «Pulsión de derrota», Santiago González; 1-5-2001 (20), «Romancero de ausencias», Santiago González; 2-5-2001 (22), «Carteles electorales», Santiago González; 4-5-2001 (22), «Progreso económico», Santiago González; (28), «Tomar fósforo», Tonia Etxarri; (37), «El Kursaal y el cambio posible», José María Calleja; 5-5-2001 (25), «La ilusión de Pollyana», Santiago González; 6-5-2001 (30), «El sirlero», Kepa Aulestia; (31), «Felipe no hace campaña», Tonia Etxarri; (32), «Yo no he sido», Santiago González; 8-5-2001 (23), «Con uñas y dientes», Santiago González; (24), «Desunión en el duelo», Tonia Etxarri; 11-5-2001 (20), «Palabras», Santiago González; (21), «Credibilidad», Tonia Etxarri. 
prensa, ya que algunos de los comentarios tuvieron su ocasión en actuaciones de la campaña electoral, fueron: falso o dudoso antifascismo; errada e injustificada invocación del caso irlandés para fundamentar su petición de diálogo, ya que en Irlanda la decisión de abandono de las armas por el IRA había precedido al proceso de diálogo; poca credibilidad de los argumentos del PNV utilizados en la campaña; camino hacia la secesión tutelada por ETA y por la intimidación nacionalsocialista; abandono por el PNV de su proyecto de autogobierno mediante la profundización estatutaria; incompatibilidad de la patria con el despotismo, terrorismo, etnocentrismo y exclusión, e identificación, por el contrario, de la patria con la sociedad moderna y abierta, democrática y libre; riesgo de que la fuerza sustituyera a la razón por la paralización y disfuncionalidad institucional ante las agresiones y la violencia de ETA; causa de la división de Euskadi; políticas de exclusión; régimen viciado que no podía prescindir de ETA y de su totalitarismo; responsabilidad de los asesinatos de ETA; y mentira y manipulación de la histo$\mathrm{ria}^{44}$.

Se habló más de ETA que de EH —ésta apenas fue mencionada-, aunque poca cosa podían añadir los comentarios que no estuviera ya dicho al escribir sobre la coalición nacionalista, dada la relación objetiva entre todos los problemas. Cuantitativamente la atención fue similar, algo menor, a la prestada al Partido Popular y al PSE. De EH se dijo simplemente que sólo representaba a sus votantes y que la radicalidad de su lenguaje y contenido iba en aumento. El recuerdo de la gravedad de la situación de los exiliados tanto fuera como dentro de su propia tierra por la intolerancia e intransigencia de ETA añade una nota más a la descripción que los comentaristas hicieron de la fracturada sociedad vasca. ${ }^{45}$

De los comentarios sobre el mundo radical, el primero, que bien podía incluirse dentro de los análisis del PNV, criticaba su incertidum-

44 El Correo 27-4-2001 (35), «¿Es el PNV antifascista?», Santiago González; 28-42001 (28), «El diálogo como táctica», Rogelio Alonso; 30-4-2001 (24), «Tres argumentos», Joseba Arregi; 1-5-2001 (28), «Contra la secesión», Antonio Elorza; 2-5-2001 (28), «Estatuto sí o no», Xavier Gurrutxaga; 5-5-2001 (33), «Un nuevo equilibrio vasco», Juan Pablo Fusi; 6-5-2001 (47), «Mi guerra civil», Fernando Savater; 8-5-2001 (32), «La muerte de un demócrata», Antonio Elorza; 9-5-2001 (34), «Imagine», Juan Manuel Eguiagaray; 10-5-2001 (35), «El Plebiscito», Manuel Bear; (34), «Las llagas del silencio», Fernando García de Cortázar; (35), «A vueltas con la historia», Santiago de Pablo; 14-5-2001 (30), «El revolcón», Santiago González.

45 El Correo 27-4-2001 (25), «Carta electoral», Xavier Gurrutxaga; (26), «Las voces ocultas», Javier Guillenea; 28-4-2001 (22), «Vidas prohibidas», Javier Guillenea; (24), «Desvaríos», Xavier Gurrutxaga; 29-4-2001 (32), «Votos de soledad», Montserrat Lluis; 3-5-2001 (23), «Llave para la involución», Xavier Gurrutxaga. La atención prestada a IU no alcanzó el $2 \%$. 
bre e indefinición ante las posibles estrategias contra ETA; el segundo pretendía descubrir los objetivos del asesinato de ETA y defendía la prioridad del dolor de las víctimas como centro de la reacción ante ETA; y el tercero mostraba la pretensión de ETA de negar no sólo la transversalidad del gobierno, sino de la nación vasca y de su construcción, y defendía la necesidad de un acuerdo general mínimo (de todos los partidos) basado en la negación de todo lo que era, defendía y significaba ETA, en cuanto paso imprescindible para la construcción de una nación civil. Ello constituía un ataque radical al PNV y confirmaba la interpretación que se viene recogiendo en este trabajo de que el PNV era parte del problema ${ }^{46}$.

Estos análisis ponían en evidencia la vacuidad de la afirmación, por abstracta e indeterminada, de que la cuestión fundamental de las fuerzas democráticas ante los asesinatos de ETA no era la composición de gobierno, sino la de organizar la unidad de la sociedad ante ETA y su entorno, punto de vista nacionalista y de otros acompañantes, que se oponía, como se ha visto, al de los que pensaban que era la coalición nacionalista la que impedía esa unidad por coincidir con ETA en los fines ${ }^{47}$.

Sólo el 25\% de los comentarios de El Mundo tuvieron por objetivo a los partidos constitucionales —el resto recayó sobre los partidos nacionalistas - y muy pocos comentaristas censuraron al PSE. Los que lo hicieron, pensaron más en cierto sector socialista, el que representaba Felipe González, y en la participación de éste en la campaña. La crítica a González completaba el apoyo del periódico al pacto entre socialistas y populares vascos ${ }^{48}$. De todo lo escrito sobre los partidos políticos, ex-

46 Ver: 29-4-2001 (29), «Nada a cambio», Kepa Aulestia; 7-5-2001 (22), «La campaña del terror», Alberto Surio; 8-5-2001 (33), «A buen entendedor», Joseba Aregi.

47 Ver El Correo 8-5-2001 (27), «Volver a la realidad», Xavier Gurrutxaga.

48 Ver: El Mundo 28-4-2001 (4), «La diferencia», Fernando Onega; El Mundo 12-5-2001 (4), «Ay, Felipe», Fernando Onega; El Mundo 6-5-2001 (11), «El favor de González», German Yanke; (11) «Los números rojos», Fernando L. Agudin; (10) «Que no cunda el pánico», Victoria Prego; El Mundo 28-4-2001 (8), «Contra el miedo las urnas», Victoria Prego; El Mundo 8-5-2001 (2), «Banderas de conveniencia», Casimiro García Abadillo; El Mundo 3-5-2001 (10), «Un problema con ventajas», Victoria Prego; El Mundo 11-5-2001 (8), «Contigo pero sin ti», Victoria Prego; El Mundo 13-5-2001 (6), «Ya estamos en trece», Julio Santibáñez; (4) «Información libre», Carlos Malo de Molina; «Pueden influir», Jorge de Estaban; El Mundo 5-5-2001 (2), «Fraga, presidente», Javier Ortiz; (14), «El plan quinquenal», Fernando L. Agudin; El Mundo 9-5-2001 (2), «Maquillando la realidad», Javier Ortiz; El Mundo 10-5-2001 (9), «Los tres monos», Fernando L. Agudin; «No son fiables», German Yanke; El Mundo 12-5-2001 (2), «Misterios de la actualidad», Javier Ortiz; El Mundo 30-4-2001 (2), «Por el imperio hacia Dios», Juan Francisco Martín Seco; El Mundo 7-5-2001 (20), «Dany el Bobo», Federico Jiménez Losantos; El Mundo 11-5-2001 (6), «La rentabilidad de los funerales», Roberto Valencia; El Mundo 12-5-2001 (11), «Por 
ceptuando lo recogido en otros lugares, el $75 \%$ tuvo que ver con el nacionalismo. Casi el 50\% se centró sobre la coalición nacionalista, substancialmente el PNV, y el 25\% sobre ETA y EH. Izquierda Unida pasó casi desapercibida con menos de un $2 \%$.

La afirmación de que había llegado la hora de Ibarretxe, que apareció al final de la campaña, no tenía otro significado que reconocer que a tenor de la encuesta del CIS, y más por el rechazo que suscitaba Mayor que por méritos propios, el ganador iba a ser el candidato de la coalición. Esto no significaba un apoyo a su candidatura; es más, estaba en absoluta contradicción con cuanto escribieron los comentaristas.

Estos escribieron que el totalitarismo de los etarras era el mismo que el soviético y el nazi y exactamente igual que el totalitarismo de los peneuvistas. Esta fue una de las más graves acusaciones dicha de manera expresa, la del Euskogulag, es decir, la de la mentira y el crimen. Hubo comentarios para denunciar el trato de favor de la Administración de justicia con el PNV, que, para colmo, se hacía pasar por víctima, y para denunciar, así mismo, su discurso apocalíptico, de miedo, fractura, ruptura y confrontación. Pero la tónica de las colaboraciones la marcaba la denuncia de complicidad e, incluso, de identidad entre los nacionalismos.

El PNV era el culpable del miedo de la sociedad vasca a una banda de pistoleros; culpable de una sociedad sin libertad ni seguridad, que olvidaba a las víctimas, actuaba como comisario político, impedía la actuación de la ertzaintza, garantizaba la impunidad de los verdugos y negaba la realidad de los hechos. Un fracasado Ibarretxe y los suyos querían seguir viviendo bien sobre la sangre de los que no encajaban en su proyecto político soberanista. Su intervención sobre el bombardeo de Gernika le costó los insultos de «lelo»y «txotxolo»; el compromiso de no gobernar con los votos de EH, el de mentiroso; y la pregunta a Aznar de si respetaría los resultados fue calificada de «bobería torticera para pazcuatos». No tenía sentido presentar a Euskadi como un sociedad modélica, cuando tenía el «pequeño» inconveniente de carecer de paz.

Algún comentarista interpretó que había llegado el fin de la patrimonialización del país por el nacionalismo y que, donde siempre se había pensado que el PNV era la solución de los problemas, era en realidad parte del problema, apreciación pocas veces dicha de manera expresa, pero que es una conclusión dominante en los periódicos, a excepción de Deia y, sólo en parte, Gara. La patria agobiante y virtual de

un líder civilizado», T. Fernández Auz; El Mundo 13.5.2001 (3), «Dos vascos y un destino», Pedro J. Ramírez; El Mundo 8-5-2001 (4), «Toda la sangre», Victoria Prego. 
los nacionalistas se enfrentaba a la de los derechos y libertades de los ciudadanos.

Mezquindad moral y bajeza humana eran atributos del PNV y EA, «compañeros de aventuras de los malhechores», formando piña en torno al nazismo, señalando a las víctimas y planificando el exterminio. Los atacados por ETA eran los acosados e insultados por los nacionalistas, que miraban para otro lado cuando actuaban los totalitarios e interpretaban el terrorismo como consecuencia de un conflicto político.

El voto nacionalista era el voto cautivo. «Chaves repartiendo subvenciones es un juego de chocolatinas, bombones y caramelos al lado de la tela de araña de los dineros públicos que manejan el cura y sus monaguillos», escribió El Mundo.

Cuando se criticó a Polanco por poner su imperio mediático al servicio de Arzalluz se dijo de éste que era «el más abyecto servidor del separatismo etarra».

De todos modos, el futuro se presentaba mejor, porque el PNV había perdido su patente de corso, su bandera de conveniencia y la rentabilidad de complejos de culpa del pasado, tal y como se recoge en otro lugar de este trabajo. ${ }^{49}$

Los análisis no hicieron más que ahondar en lo visto anteriormente: la complicidad, la política sin principios, la culpabilidad y la convergencia de estrategias. Hubo una añadidura que brindó al PNV la lección de la Lliga Regionalista catalana en relación al terrorismo: la unidad con España y el autogobierno ${ }^{50}$.

Las acusaciones contra ETA y EH de totalitarismo, nazismo, terrorismo y otras muchas, ya están recogidas en otros momentos. Aquí se

49 Ver para todos estos puntos El Mundo 27-4-2001 (4), «Euskogulag», Federico Jiménez Losantos; «Varios manojos de nervios», Roberto Valencia; 28-4-2001 (4), «Unas elecciones para la esperanza», Gustavo de Arístegui; (5), «Gernika», Martín Prieto; (9), «El miedo al miedo», Fernando L. Agudin; «El fin de la transición», German Yanke; (13), «Los estigmas del fracaso de Ibarretxe», Isabel San Sebastián; 29-4-2001 (12), «López deLacalle, ultrajado», Ernesto Ladrón de Guevara; (14), «Los perseguidos», German Yanke; 4-5-2001 (9), «El día de Ibarretxe», German Yanke; 5-5-2001 (5), «La campaña», Martín Prieto; 5-5-2001 (14), «Sentido común», German Yanke; 6-5-2001 (6), «Ya han pactado», Esteban González Pons; 7-5-2001 (5), «La campaña sigue adelante», Victoria Prego; 9-5-2001 (4), «Proetarras», Federico Jiménez Losantos; (5), «El PER del miedo», Antonio Burgos; (9), «El proyecto de EH», Germán Yanke; 10-5-2001 (4), «Polanko», Federico Jiménez Losantos.

50 Ver: El Mundo 29-4-2001 (3,4), «Ver, oír y callar», Pedro J. Ramírez; El Mundo 6-5-2001 (6), «Todo es distinto», Javier Ortiz; El Mundo 11-6-2001 (4), «Los enemigos de la construcción nacional», José María Marco; El Mundo 12-5-2001 (30), «Desde donde cría la serpiente», Isabel San Sebastián;. El Mundo 12-5-2001 (4), «Una jornada de reflexión para los vascos», Jon Juaristi. 
trata de destacar ciertos aspectos, que, en buena medida, los provocó el asesinato cometido por ETA en plena campaña, y que en algún caso excepcional rompieron la unanimidad del periódico. Entre estos están el cambio de opinión en Europa con respecto a ETA; la fragilidad de algunas consecuencias deducidas por los comentaristas; la propuesta de gobierno de concentración en clara oposición a todo lo defendido por $E l$ Mundo; la aceptación por algún comentarista de la tesis nacionalista de que el terrorismo y asesinatos favorecían al Partido Popular y perjudicaban al PNV; la llamada a la defensa de España —identificada con la defensa de la libertad - y al uso contra ETA de algo más que votos; la consideración del PNV como protegido del «gánster», ETA; la llamada a la paciencia ante el nacionalismo criminal, y la pregunta de si merecía la pena la nada carcelaria por una patria vasca que nunca existiós ${ }^{51}$.

En El País el Partido Popular (no hubo crítica directa al PSE) —aparte de lo que se escribió contra él en artículos, cuyo objetivo nuclear no era su censura, sino otro cualquiera de los puntos hasta ahora vistosfue dura y directamente criticado por el escándalo de la ocultación de la encuesta del CIS, por identificar, tanto él como los medios de comunicación de su influencia, el nacionalismo vasco con el terrorismo, por la estrategia irracional seguida contra el PNV y por ayudar a la recreación del fascismo hispano. En total no pasó del 15\% lo dedicado a este partido, lo mismo que a ETA y Euskal Herritarrok ${ }^{52}$.

El 70\% de los comentarios y análisis se centraron en la coalición nacionalista. Etica heladora, de palabras de solidaridad, pero de pocos gestos de sustancia ética, es la que se atribuía al nacionalismo gobernante con las víctimas. Lizarra había adormecido al PNV hasta el punto

51 El Mundo 29-4-2001 (10), «En el nombre de Europa», Victoria Prego; El Mundo 7-52001 (5), «La campaña sigue», Victoria Prego; El Mundo 8-5-2001 (16), «ETA no se vota», Federico Jiménez Losantos; El Mundo 8-5-2001 (17), «Pereza y gula», Raúl del Pozo; El Mundo 7-5-2001 (8), «Un voto nada secreto», Fernando L. Agudin; El Mundo 8-5-2001 (4), «Pecados políticos», Fernando L. Agudin; «Ibarretxe en Zaragoza», German Yanke; El Mundo 10-5-2001 (9), «Los tres monos», Fernando L. Agudin; El Mundo 12-5-2001 (5), «La tigresa», Martín Prieto; El Mundo 11-5-2001 (4), «El largo plazo», Federico Jiménez Losantos.

52 Ver El País 13-5-2001 (Domingo, 6), «En pantuflas», Javier Pradera; ver, también, del mismo autor «Los electores vascos juegan a los dados» en El País 9-5 2001 (15), y «Estropicios» de Emilio Alfaro en El País 10-5-2001 (20); El País 11-5-2001 (15), «Las encuestas de la confusión», Soledad Gallego-Díaz; El País 4-5-2001 (30), «Callejón sin salida», Javier Pérez Royo; El País 28-4-2001 (24), «Dimensión española de la campaña vasca», Fernando Vallespín; en p. 26 Emilio Alfaro, en «El muro», destaca la incomunicación absoluta entre los líderes de los partidos; El País 5-5-2001 (12), «Construir la historia o el fantasma del nacionalismo», Fermín Bouza. 
de impedirle la verdadera compasión de padecer con las víctimas. No se conocía un caso de vecinos o militantes de partidos nacionalistas que se hubiesen ofrecido a proteger a un amenazado. La ausencia de solidaridad impedía neutralizar la táctica de ETA de socializar el sufrimiento de forma discriminatoria y evitar, así, que se ahondase la sima entre los amenazados y los no amenazados. Algo fallaba, cuando los que no sufrían la violencia, identificaban su fin con la paz, mientras que los que la sufrían, la identificaban con la libertad ${ }^{53}$. Esta denuncia entroncaba con la que otros comentaristas llamaban la irresponsabilidad ante el sufrimiento o la banalización del mal y que en algún caso se personificó en el candidato nacionalista, Ibarretxe ${ }^{54}$.

Lo recogido hasta aquí habla de insensibilidad ante el dolor, de insolidaridad, de incumplimiento de la primera función del poder político - la protección y seguridad de los ciudadanos-, de dirigentes mentirosos y de la religión del nacionalismo. El análisis más detallado sobre la coalición nacionalista insistió en la denuncia de otros aspectos, el primero de los cuales fue el de la complicidad con ETA y el mundo abertzale. Complicidad por preparar y justificar los crímenes de ETA y por participar en la política de exclusión y deportación de los no nacionalistas; complicidad en limitar la libertad de expresión y participación política por abandono de las obligaciones de gobierno; complicidad en la probable responsabilidad de la violencia por culpa, no

53 El País 2-5-2001 (17), «Etica gélida», Emilio Alfaro.

54 El País 3-5-2001 (8), «Dioses», Luis Daniel Izpizua; El País 11-5-2001 (22), «Atípica alternancia», Emilio Alfaro. El mismo autor en otro comentario - (22), «La Iglesia vasca, después de Setién»— trataba de explicar que la crítica de ETA al clero vasco por su falta de neutralidad en el «conflicto» se debía a los cambios operados en el discurso sobre la violencia a partir de la jubilación de Setién, que habría dejado de ser imparcial para comprometerse con una de las partes, las víctimas de la violencia; El País 4-5-2001 (22) «La irritación de Euskal Herritarrok», Soledad Gallego-Díaz; El País 5-5-2001 (20), «Depende», Emilio Alfaro. También Alberto Reig Tapia justificó el deber de los ciudadanos de sustituir al gobierno nacionalista por no haber sabido garantizar el derecho a vivir en paz de todos los ciudadanos. Sólo el demócrata por encima de cualquier otra ideología y no el patriota nacionalista por encima de su democracia defendía la libertad; éste, por el contrario, era el auténtico liberticida. Esta era la idea básica del autor, que veía en Basta Ya la mejor fusión de política y moral y, por el contrario, censuraba a Sabino Arana, a los actuales ayatolás y a los que hablaban de violencia y violencia política, cuando se practicaba la extorsión, el crimen y el desprecio a la vida y existían verdaderas mafias. Había que sustituir a los que sólo creían en la soberanía popular y en las elecciones mientras les favorecían (El País 11-5-2001 (24), «Patria y libertad»); El País 4-5-2001 (28), «El PNV busca nuevas oportunidades tras el fracaso de Lizarra», Luis R. Aizpeolea; «Gobernar con IU», L.R. Aizpeolea; (29), «¿Continuidad o cambio?», Imanol Zubero; El País 6-5-2001 (5, Domingo), «Contra la resignación», Santos Juliá; El País 13-5-2001 (Domingo, 7) «Votar, vivir», Santos Juliá. 
directamente de la educación, sino de las carencias del sistema político nacionalista (discurso de deslegitimación del Estado, la identidad de fines políticos con ETA, intento de neutralización de la rebelión ciudadana, fomento desde el poder de un sentimiento romántico, melancólico, agónico, agraviado de lo vasco); complicidad en el disfrute de los beneficios del mismo sistema; y complicidad por sacar provecho del terrorismo para la soberanía u otro tipo de ventajas políticas. El segundo aspecto fue que ni el PNV ni Ibarretxe resultaban creíbles. El tercero - que afectaba a la actitud del nacionalismo ante el pluralismo- era una crítica al modelo nacionalista de «identidad en la derrota», que negaba una identidad vasca basada en el pluralismo de la sociedad existente y persistía en el error de una estática identidad ${ }^{55}$.

Sólo el $15 \%$ de los comentarios hablaron expresamente sobre ETA. Entre lo más destacable cabe reseñar el intento de explicación de la inexistencia de un enfrentamiento civil en el País Vasco que, de haberlo, sólo existiría entre las fuerzas políticas. La dialéctica de las dos comunidades enfrentadas no se había producido, no sólo por la madurez de la sociedad vasca, sino por el elevado nivel de bienestar económico, aunque (adelantando, tal vez, la poca consistencia de esta explicación) el autor opinaba que casi era un milagro que la sociedad vasca, sometida por la persistencia del terrorismo a un permanente escrutinio sobre el sentimiento de identidad y pertenencia, mantuviera un nivel aceptable de cordura e integración. La «solución final» emprendida por ETA, por otra parte, había desplazado la posible línea de fractura social entre nacionalistas y no nacionalistas a una nueva situada entre los amenazados y quienes todavía no lo estaban ${ }^{56}$.

El mismo autor, dispuesto a analizar la estrategia de ETA para dominar el nacionalismo, observó la presencia omnipresente y condicionante de casi todo por parte de ETA, bien matase o no. Partiendo de que los votos no le interesaban de manera substancial, más bien los despreciaba, el autor destacaba que algunos «augures» («hablar de análisis en este asunto es impostura») pronosticaban que ETA se abstendría de matar en el País Vasco hasta el día 13 para evitar que los escaños de

55 Ver El País 2-5-2001 (16), «Matar y excluir», Javier Pradera; El País 12-5-2001 (20), «Libertad o miedo», Francisco José Llera Ramo; El País 13-5-2001 (24), «El auge de la cultura de la violencia aturde a la sociedad vasca», José Luis Barbería; El País 13-5-2001 (20), «Los miedos enfrentados», Herman Tertsch; El País 2-5-2001 (11), «La democracia en el País Vasco», Gregorio Peces-Barba Martínez; El País 6-5-2001 (4, Domingo), «Ordago a pares», Javier Pradera; El País 8-5-2001 (2, País Vasco), «Palabra de vasco», Javier Ugarte; El País 10-5-2001 (15), «Se elige al sucesor de Ardanza», Patxo Unzueta; El País 10-5-2001 (8, País Vasco), «Pluralismo en Euskadi», Imanol Zubero.

56 El País 30-4-2001 (24), «La línea de quiebra», Emilio Alfaro. 
EH bajaran de 9 o 10 y tener, así, los suficientes para o bien otorgarle el poder al PNV o bien mandarlo a la oposición. Eso era lo que reclamaba su estrategia para hegemonizar al nacionalismo vasco. ${ }^{57}$

Los hechos se encargaron de demostrar que la idea muy compartida de que ETA se abstendría de matar ante las malas perspectivas electorales de EH era falsa. El asesinato iba a marcar el último tramo de campaña. ETA, escribía, daba por perdidos los más de 60.000 votos ganados anteriormente por EH, prefiriendo «remarcar la férrea supeditación del brazo político al puño militar». ETA, aunque últimamente había hecho política para dividir a los demócratas y llevar a los nacionalistas al soberanismo, su capacidad de influencia en la sociedad vasca estaba en la violencia. El asesinato destacaba dramáticamente que lo que estaba en juego urgentemente no era sólo el resultado electoral y su consiguiente gobierno, sino la reconstrucción de la unidad de los demócratas contra el desafío de los violentos. ETA había vuelto a recordar algo que se había difuminado en el debate electoral y que podía llevar a pensar que el discurso constitucionalista era victimista, irreal y exagerado, que el primer «conflicto político» de Euskadi era el de afirmar la vida y la libertad de las personas. El crimen de ETA, además, interpelaba directamente a un PNV situado en tierra de nadie, entre violentos y víctimas. El PNV no acababa de darse cuenta, según el analista, de que la estrategia de aquéllos con quienes dijo compartir fines pasaba por suplantarle como fuerza hegemónica del nacionalismo. Para ello necesitaba «aislar al PNV del resto de las fuerzas democráticas» y debilitar los lazos esenciales de solidaridad que debían vincularle a ellas, especialmente cuando sufrían el azote de la violencia. ${ }^{58}$

La incomprensión en Europa de que en un país democrático con alta renta nacional parte del electorado, anteponiendo las reivindicaciones nacionales a los derechos humanos y a las reglas de juego - como los fascistas - votase al terrorismo en lugar de recurrir a la vía democrática llevaba al europeo medio a mirar para otro lado cuando ocurría algún asesinato ${ }^{59}$, lo que significaba indiferencia ante el dolor y la libertad. Frente a esto la mayoría de los comentaristas expresó la convicción de que el miedo a perder la democracia y la Constitución las había convertido en más valiosas. El descubrimiento de semejante valor se

57 El País 3-5-2001 (20), «La presencia», Emilio Alfaro.

58 El País 7-5-2001 (17), «ETA enseña sus cartas», Emilio Alfaro. El análisis es muy sugerente, pero silencia que también el PNV buscó lo mismo en Lizarra: hegemonizar el nacionalismo y la sociedad, para lo que era imprescindible que ETA renunciara a su única ventaja, la de la violencia.

59 El País 4-5-2001 (6), «El 13 de mayo, fecha clave», Ignacio Sotelo. 
debía en buena medida a ETA, que había hecho evidente que la independencia podía traer la tiranía. ${ }^{60}$ Los numerosos comentarios del día de la votación llamaron de una forma u otra a votar contra ETA y EH.

El diario nacionalista Deia repitió la campaña de la coalición cuantitativa y cualitativamente. La identificación entre el periódico y la coalición y entre el tipo de campaña de los colaboradores y el de los políticos fue total. En torno al $60 \%$ de los textos firmados sobre partidos tuvo por objetivo a los integrantes del españolismo, nacionalismo español, frente o bloque españolista, según las distintas denominaciones de los comentaristas. Fue el Partido Popular con el 70,66\% de todos estos comentarios el centro de atención. Por importante que fue la defensa e identificación del periódico con la coalición nacionalista, fue mayor la estrategia de desprestigio y acoso contra los populares. Medios de comunicación, socialistas, jueces y asociaciones como Basta Ya formaban una unidad dirigida y dominada por el Partido Popular. En este sentido se escribió hacia la mitad de la campaña que el PP había encontrado valiosos compañeros de viaje en los medios de comunicación, en los jueces, en los socialistas, en los intelectuales casquivanos y agradecidos, gracias, además, a ETA y su entorno, para volver a los valores del anterior régimen ${ }^{61}$.

Los contenidos de las denuncias contra el Partido Popular pertenecían a un corpus nacionalista acomodado a la campaña y a los acontecimientos que la rodearon. Eso ocurrió, por ejemplo, con el debate, las palabras de Fraga sobre el euskera, el asesinato de ETA o determinadas actuaciones judiciales. La campaña fue la ocasión para decir lo mismo de siempre. Y lo de siempre fue la lucha del nacionalismo español contra el nacionalismo vasco, la del españolismo contra el vasquismo con los rasgos permanentes de la violencia, la imposición lingüística y cultural, el chovinismo, la intolerancia, la continuidad del franquismo, la negación del Estado de derecho (mediante el sometimiento del poder judicial al gobierno) y la ineficacia.

Todo esto se acomodó en la primera semana de campaña mediante la denuncia, varias veces repetida, del rechazo del diálogo; las huidas y espantadas de Mayor ante Ibarretxe; la pretensión de conquistar las instituciones vascas para deshacer la recuperación de su patrimonio y restituir la cultura, la lengua y la historia españolas; las tonterías, ignorancia, incultura, frivolidad y disparates de Fraga sobre el euskera; la demonización de la lengua vasca; las acusaciones contra AEK y la negación de subvenciones; las alabanzas al ministro francés Jack Lang

60 El País 2-5-2001 (2, País Vasco), «Cambio de régimen», Ainhoa Peñaflorida.

61 Deia 6-5-2001 (34), «Ez naiz Pilarica», Mikel Atxaga. 
por la incorporación del bilingüismo a la enseñanza y críticas a las palabras del rey sobre la no imposición del castellano; el chovinismo, nacionalsindicalismo y la lepra de España; la invención del miedo en Euskadi; la comparación de las palabras del Arzobispo de Sevilla a favor de los obispos vascos con el comportamiento del clero vasco durante la guerra civil, sugiriendo así la identificación de los populares con el franquismo y de los vascos con el antifranquismo; y las dudas, que parecían afirmaciones, sobre la posible conexión entre Mayor y el juez Garzón con su consecuencia de más cárcel para Euskadi. ${ }^{62}$

La segunda semana conoció la repetición de algunos de estos extremos y añadió el silenciamiento de la oposición (acusación hecha por una pluma socialista); la defensa del PNV, Arzalluz e Ibarretxe por su declaraciones sobre los asesinatos y futuro gobierno sin los votos de EH; la interpretación, como «última ocurrencia del frente españolista», de la solicitud de renuncia a los escaños de EH para gobernar; la calificación de virrey conquistador, destructor de las libertades y amenaza para el pueblo vasco dada a Mayor; la repulsa de todo lo vasco hecha por los «alguaciles» del idioma; la persecución franquista del euskera y catalán; la utilización electoral de la «muerte» de Giménez Abad, cuando había sido un poco la muerte de todos, lo cual no ayudaba a la acción conjunta contra la violencia; la defensa de la buena voluntad y diálogo para vencer a ETA en lugar de la estrategia policial y de enfrentamiento de Mayor; las acusaciones de complicidad del nacionalismo democrático, especialmente el PNV, con los asesinos, mentirosos y totalitarios de ETA; la intencionalidad política de ETA de favorecer el triunfo del PP a costa del PNV; la pretensión de acabar con el nacionalismo y no con ETA; la ocultación de la encuesta del CIS; la siembra del odio entre abertzales y españoles atribuida a Mayor; el recurso al juez Garzón — «práctica de las cloacas y de la mano negra»- para ilegalizar Haika y, así, frenar el traspaso de votos de EH al PNV, permitir un gobierno españolista en Ajuria Enea, reforzar los argumentos poli-

62 Deia 1-5-2001 (26), «El otro órdago a Mayor», Xavier Lapitz; 2-5-2001 (31), «Patriotas con cabeza de cartón», Josu Erkoreka; 3-5-2001 (11), «Fraga arremete contra el euskera, Mayor Oreja calla», J.C. Ibarra; (20), «El elector y sus derechos», Patxi Zabaleta; «Sucia campaña electoral», Pablo Beldarrain Solatxi; «Fraga nunca defrauda», Juan Carlos Latxaga; (32), «Los amigos italianos de Aznar», Kepa Bordegarai; (33), «Macanas», Xavier de Antoñana; «Justo apoyo a los obispos vascos», Agustín Altamira; 4-5-2001 (10), «Mayor responde a Redondo; "sî", pero con mayoría absoluta», J.C. Ibarra; «Don Manuel y los extraterrestres», Paco Gandoy; (25), «¿Iribarne es un apellido con polvo de museo?», José Luis Iturrieta; (28), «Emociones en torno al euskera», Xavier Lapitz; (30), «El barullo electoral», Gabriel Mariscal; «El efecto de la desmemoria», J.J. Ramírez de la Piscina; (31), «La credencia vasca», Joaquín Navarro. 
ciales de Mayor y promover las tesis más inmovilistas de EH; la parálisis y retroceso de la sociedad alavesa por culpa del modelo de gobierno popular en Alava y Vitoria; la denuncia de que la vía policial eternizaría el conflicto y lo extendería hacia las capas más populares ante la protección de los dirigentes; y la política de reducción de la autonomía vasca. ${ }^{63}$

Partido Popular y Partido Socialista fueron interpretados como parte de un todo. Era de esperar que estaría firmado hasta un reparto del poder en el que el PP cedería al PSE la lehendakaritza para quedarse con las carteras más importantes. Mayor tendría, así, extendida la alfombra roja para volver a Madrid, una alfombra barrida por el PSOE. Esta identificación era una acusación contra Redondo, ya que diversos comentarios insistieron en que Zapatero se distanciaba de Redondo, González coincidía con Ibarretxe y Odón Elorza estaba por el diálogo sin exclusiones y por la no violencia. Por lo demás, el españolismo y la marginación del euskera en la campaña situaban a los socialistas en la coincidencia permanente con la derecha española. Lo que cabía esperar de su acceso al gobierno sería la reducción de la autonomía a una descentra-

63 Deia 5-5-2001 (11), «Ibarretxe pregunta a Aznar si aceptará los resultados», J.C. Ibarra; (32), «"Vacas locas" y control parlamentario», José Luis Uriz Iglesias; «Leopoldo Barreda y el euskera de Ibarretxe», Martín de Arribillaga; (33), «De nuevo, el inefable Fraga», Joselu Cereceda; 6-5-2001 (34), «De Felipe González a Aznar», Xavier Lapitz; «Vetado por nacionalista», Amaia Fano; (36), «Dime quién te aplaude y te diré quién eres», Iñaki Anasagasti; 7-5-2001 (25), Xavier Lapitz; 8-5-2001 (11), «El respeto que se debe a un recién fallecido», Juan José Baños Loinaz; (11), «La fractura política marcó el día después del atentado», J.C. Ibarra; (16), «Que se vayan», Joaquín Navarro Esteban; (17), « ETA intenta marcar el ritmo», José Luis Uriz Iglesias; (30), «Bai, bakea behar dugu», Amaia Fano; 9-5-2001 (2), «Las opciones, los sondeos y las posibilidades», Juan José Baños; (11), «Las campañas se renuevan mientras aún resuenan los insultos», J.C. Ibarra; (12), «El día después del día después», Paco Gandoy; (28), «Manipular las urnas desde la pantalla», José Luis Iturrieta; (30), «Los embustes de Pío», Amaia Fano; (31), «Infancia precoz», Juan Carlos Latxaga; 10-5-2001 (2), «La palabra, la intención y los intérpretes», J.J. Baños Loinaz; (9), «Los partidos ponen la lupa sobre el "fruto prohibido» del CIS», J.C. Ibarra; (26), «¿Pero, qué cachondeo es éste?», Xavier Lapitz; «Los votos de la discordia», Amaia Fano; (29), «De votos y debates», José Ramón Blázquez; 11-5-2001 (2), «Hoy llega el gran final... ¿o el gran principio?», J.J. Baños; (9), «Garzón eclipsa a Aznar y Zapatero en la recta final de la campaña», J.C. Ibarra; (24), «Le regalo un poemario "guerrero" a Iturgaiz», José Luis Iturrieta; (28), «Y Garzón entró en campaña», Xavier Lapitz; «¿Y qué hará cuando pierda...?», Amaia Fano; (30), «¡Oye ETA mi aflicción...!», Angel Gaminde Montoya; «El modelo del PP hace aguas en Alava», María Jesús Agirre; 12-5-2001 (26), «Un rápido resumen de mensajes», Xavier Lapitz; «Apuntes para una reflexión», Amaia Fano; (29), «Generosidad y centralismo», Gorka Knör Borrás; «Un debate clarificador», José Ignacio Bajo; 13-5-2001 (26), «La ¿nueva? derecha europea», Xavier Lapitz; (32), «Guía para discretos», Antonio Alvarez Solís; Deia 3-5-01 (20), «Sucia campaña electoral», Pedro Beldarrain. 
lización administrativa. Deia escribió que para la coalición PP-PSOE todo lo que no fuera obtener la mayoría absoluta sería un fracaso rotundo, cuyas consecuencias serían una nueva espantada de Mayor Oreja - por anteponer siempre su propia carrera política a cualquier otra cosa-, la posible aceptación de la Lehendakaritza por Redondo - sometido a la paradoja de una coalición minoritaria y de la minoría de su partido dentro de la propia coalición con, tal vez, resultados favorables electorales para el PP, contradicciones en su partido y un cambio de rumbo postelectoral-, y la paradoja mayor de pretender ser la alternativa al PP en España haciendo seguidismo del propio gobierno en el asunto más trascendental, la cuestión vasca. Ahora bien, el cambio que ofrecía esta coalición era el de la marcha hacia atrás desde el autogobierno a la descentralización administrativa, porque nada más se podía esperar de quienes no habían completado el Estatuto y lo habían considerado carta otorgada. ${ }^{64} \mathrm{Al}$ PSOE se le situó en «el limbo político tradicionalmente reservado a los monaguillos de la derecha» y a Redondo se le consideró «un caso grave de ignorancia palmaria o de ligereza irresponsable» ${ }^{65}$.

Irrupción de la España nacional con sus programas de radio al servicio de «la cosa»; carroña radiofónica; espiral del silencio (expresión utilizada en comentarios de diverso signo político) de las grandes campañas mediático-judiciales; guerra mediática; descalificación de los obispos, siguiendo el modelo de Goebbels, por no cubrir «con el palio sagrado» el pacto PP-PSOE y negarse al «cesaropapismo constantiniano o franquista»; feroz campaña nacional e internacional no contra ETA, sino contra el nacionalismo vasco democrático; tertulias que destacaban el ambiente de guerra civil; descalificaciones y acusaciones contra los obispos; simplificación de la problemática de Euskadi; antinacionalismo vasco; prensa de partido; mentiras sobre el miedo en Euskadi; apoyo de los medios a los partidos constitucionalistas en perjuicio de los nacionalistas en trato, tiempo, insultos, silencios y marginación; intoxicación de la prensa y radio; campaña mentirosa de desprestigio

${ }^{64}$ Deia 9-5-2001 (20), «El cambio, iqué cambio!», Txema Montero; 1-5-2001 (9), «Mayor continúa llevando de la mano al PSE "por la buena senda"», J.C. Ibarra; 4-5-2001 (28), «Zabaleta y Elorza en positivo», Amaia Fano; 5-5-2001 (11), «Ibarretxe pregunta a Aznar si aceptará los resultados», J.C. Ibarra; (32), «Leopoldo Barreda y el euskera de Ibarretxe», Martín de Arribillaga; 6-5-2001 (2), «A caballo entre las entrevistas y las encuestas», J.J. Baños; (34), «De Felipe González a Aznar», Xavier Lapitz. En Deia 29-4-2001 (33), «Lo mejor de lo mejor», Juan Carlos Latxaga, las palabras de Redondo en el acto del Kursaal se califican de «caso evidente de obediencia debida».

65 Deia 9-5-2001 (32), «El 13 de mayo, elección», Luis M. ${ }^{a}$ Retolaza y Ramón Labayen. 
internacional, nacional, política y religiosa sobre el nacionalismo y la situación de Euskadi; interpretaciones a la carta de los sondeos; uso abusivo de los medios públicos de comunicación; brunetes mediáticas ( «se mata con las pistolas y con la mentira. Con la chulería de una mayoría que pretende pisar la libertad y dignidad de un pueblo, lo dijo Joaquín Navarro Esteban») y «jauría mediática gubernamental» son el resumen de lo que se escribió contra uno de los soportes de la opción del Partido Popular, los medios de comunicación. ${ }^{66}$

La contestación a la intervención de algunos intelectuales en la campaña de los partidos constitucionalistas siguió el camino del ataque personal y no el de la argumentación. No eran todos los intelectuales españoles, sino sólo los que amparaban el nacionalismo español en el momento en que España, de la mano de Aznar, había vuelto a amanecer. Así se explicaba en un artículo que trataba, además, de describir la relación entre tales intelectuales y varias asociaciones. En el grupo de intelectuales pro nacionalismo español estaban los vascos Jon Juaristi y Savater, a quienes les separaba no sólo la opción por Mayor o Redondo, sino el sueldo. El que más cobraba, Juaristi, pedía el voto para Mayor; Savater, al que había tocado la dieta, lo pedía por Redondo, a la espera de la nómina. No convencían al autor los intelectuales que estaban siempre a favor del poder. Y, a partir de la rectificación de la «mentira» del Foro de Ermua sobre la supuesta propuesta de la asociación para el premio Nobel de la paz, que al autor no le pareció cosa baladí, escribió: «La mentira, y siendo generosos la falta de rigor, es un arma habitual de la presunta intelectualidad que luego ha derivado en un variopinto grupo de presión: unas veces se llama Basta Ya y otras

66 Ver Deia 27-4-2001 (12), «La radio, electrodoméstico para el potaje», Paco Gandoy; 28-4-2001 (12), «Desprecio a las reglas de juego», Paco Gandoy; 29-4-2001 (10), «El bombardeo de todos los días», Paco Gandoy; 30-4-2001 (2), «De algunos osos entre la mofa y la solemnidad», Juan José Baños; (8), «"Cope”ración», Paco Gandoy; (22), «La división acorazada», Joaquín Leguina; (23), «¿Salvar los muebles?», Alfonso Arnau Torres; 1-5-2001 (10), «El altavoz del frente», Paco Gandoy; (30), «Los obispos y la paz», José Ramón Scheifler; 2-5-2001 (10), «Los episodios nacionales o las crónicas de un pueblo imaginario», Paco Gandoy; (28), «Los otros agentes de campaña», Xavier Lapitz; «1..$^{\circ}$ de mayo, día de los sindicatos», Amaia Fano; 3-5-2001 (12), «Los nuevos géneros radiofónicos», Paco Gandoy; (20), «Sucia campaña electoral», Pablo Beldarrain Solatxi; 4-5-2001 (18), «Limpios de pecado», Pello Salaburu; 5-5-2001 (11), «Ibarretxe pregunta a Aznar si aceptará los resultados», J.C. Ibarra; (12), «Encuestas, mentiras y otras técnicas», Paco Gandoy; (30), «Encuestas para la papelera», Xavier Lapitz; 6-5-2001 (19), «Carta abierta al Sr. Mayor Oreja», Koldo Alday; 7-5-2001 (26), «La gran mentira, el gran error», José Ramón Scheifler; 9-5-2001 (12), «El día después del día después», Paco Gandoy; (28), «Manipular las urnas desde la pantalla», José Luis Iturrieta; (30), «Los embustes de Pío», Amaia Fano; 10-5-2001 (29), «Los mimbres y los cestos», Josu Erkoreka; 12-5-2001 (26), «Un rápido resumen de mensajes», Xavier Lapitz. 
Foro El Salvador o Plataforma por la Libertad. Suena todo muy bien, pero mienten más que hablan» ${ }^{67}$.

La crítica a los intelectuales participantes en un debate en Antena 3, que parecían ser José María Calleja y el pintor Ibarrola, contenía comentarios despectivos de tipo personal acompañados de la habitual interpretación nacionalista que veía el nacionalismo en medio de dos frentes con víctimas y dolor por ambos lados y que rechazaba, por supuesto, el olvido de una de las partes, pero, además, la acusación de complicidad del silencio ante las víctimas actuales. «Dijo cosas muy interesantes - se refería a unos de los comentaristas-, vistas desde prismas lejanos. Monotema, la violencia, el miedo. Ellos los sufridores. Nosotros, los cómplices. Por silenciosos. Pues muy bien. Hablaron luego las víctimas. Sólo las de un lado de la campaña. Madres, esposas, hijos. Que han sufrido el zarpazo de la barbarie. Un respeto a su dolor. Pero no hubo referencia alguna a otros dolores en la trinchera de enfrente. Ya digo, un canto a la objetividad» 68 .

En un mismo artículo de «opinión» el autor del mismo recordaba su regreso del exilio y, en relación a Fernando Savater, la distancia que había entre lo protagonizado por él en la campaña en el Kursaal y lo que había escrito en años anteriores en periódicos como El País y Egin, de los que se transcribían textos mal citados y que no clarificaban nada. Sólo era nítida la calificación de su ataque al «nacionalismo democrático» en el acto de San Sebastián: injusto y calumnioso y, sobre todo, inquietante en quienes decían «apostar por la convivencia». Savater no buscaba la paz ni la libertad; simplemente daba vueltas sobre sí mismo como cuando era crío, «importándole un bledo su labor destructiva de una posible convivencia ${ }^{69} \gg$.

${ }^{67}$ Deia 9-5-2001 (30), «No fue un simple desliz», Xavier Lapitz. En Deia 29-4-2001 (32), Amaia Fano, se califica a los intelectuales que intervinieron en el acto de «iluminados»; ver, también, 12-5-2001 (26), «Apuntes para una reflexión», de la misma autora, citado anteriormente.

68 Deia 12-5-2001 (23), «Hoy toca silencio a la clase política», José Luis Iturrieta.

69 Deia 13-5-2001 (29), «Tuve un compañero de pupitre apellidado Fernández Savater», Iñaki Anasagasti. En un comentario (de tópicos de campaña y ataques personales) Emilio Olabarría Muñoz escribió que la guerra civil de Savater era una de las reflexiones apocalípticas de la campaña para el caso de que ganase la coalición nacionalista. Era la apelación al voto del miedo, un tal dislate político que los medios de comunicación de dependencia o afinidad gubernamental habían intentado ocultar. Probablemente tenían carácter delictivo y si las hubieran dicho otros portavoces políticos, no serían descartables las diligencias pertinentes por parte de la Fiscalía General por intimidación según el artículo 146 del Código Penal. Tales manifestaciones (pasando al ataque personal) ponían en entredicho la formación impartida por este profesor en la universidad y, sobre todo, teniendo en cuenta que en los veinte años de gobierno nacionalista, que había llevado al país a sus más altas cotas de 
Fue en el insulto, donde de manera más clara y contundente los comentarios de Deia expresaron la amalgama de los políticos, populares y socialistas, con los intelectuales, Basta Ya, medios de comunicación, magistrados y Junta Electoral. Así se hizo en un artículo, en teoría, de opinión sobre los derechos de los electores, en el que el articulista unió las descalificaciones de Mayor Oreja - político fracasado, sargento chusquero de la política, «fatxa», monaguillo de los ultranacionalistas del imperio, abrazado a los del bombardeo de Gernika-, las de Fernando Savater - maestro de la vieja ética de Goebels, internacionalista para ocultar su ultraespañolismo-, las de Mikel Azurmendi —ideólogo según las modas, hombre de no fiar-, las de Ibarrola - eterno defensor del centralismo, seguidor de los mecenas, que nunca había dicho que el nacionalismo fuese democrático — y las de Boadella — profesional del sarcasmo y de la ironía, sometido al capricho del poderoso o comunicador de lo contrario de lo que se le entendía-. Estas eran las cuatro patas de la «butaca orejera», los paracaidistas de las miserias más graves de Basta Ya. El artículo, anunciado para defender que la dignidad de los electores exigía el reconocimiento de la primacía de los derechos de los electores, su igualdad, la claridad y la concreción de los mensajes, terminó pidiendo el voto contra Mayor Oreja, previas las descalificaciones aludidas y las denuncias de la manipulación de los censos - caso del cuartel de Intxaurrondo por incluir a las familias de los guardias - y de la calificación de los electores de la Izquierda Abertzale como malditos. ${ }^{70}$

En el acto de Basta Ya en el Kursaal los políticos actuaron con «carga de exclusión» hasta el punto de que, si lo hubiera hecho algún político nacionalista, habría dado lugar a un nuevo capítulo del informe de Alvaro Gil-Robles; los intelectuales fueron unos iluminados; las palabras de Redondo expresaron obediencia y «calentura electoral»; los presentes, una cuadrilla; y los destacados intelectuales de la cultura euskaldun brillaron por su ausencia. Según el comentarista, el acto había reunido a madrileños - personas que «preconizan y participan de un poder absoluto, vertical, autocrático»- y a pocos euskaldunes - los que de verdad dan carácter a lo vasco. «Colosal manipulación», «venta barata de emociones», manifestación de cosas tremendas, intelectuales

bienestar económico y social (sin ninguna explicación objetiva), no había habido ningún atisbo de guerra civil, quien se estaba preparando para la guerra era o Savater o alguno de sus seguidores. Lo más probable era que sobrasen tales reflexiones, decía el articulista, y lo más que podía suceder era que alguno no fuera Consejero de Educación, si ganaba la coalición nacionalista. Al recurrir al miedo y al desgarramiento apocalíptico, es que se daban las elecciones por perdidas. (Deia 1-5-2001 (18), «La guerra civil de Fernando Savater»).

70 Deia 3-5-2001 (20), «El elector y sus derechos», Patxi Zabaleta. 
acunados por la cuestión vasca, «jinetes de Kazán» que volverán después de Mayo, «mitin contra la libertad de un pueblo», eso fue el acto. Según las palabras (insultantes e inaceptables) como las de Azurmendi - el euskera es la única lengua del mundo que mata- se creaba el caldo de cultivo de otras mentiras, como las que se vertían sobre las ikastolas o sobre la cultura vasca. ${ }^{71}$

Grandilocuente, vacío y falso era el discurso del «jefe del cuartelillo» que se paseaba por tierras vascas con toda su cohorte, en la que también estaban «intelectuales eunucos de su concubinato particular». Este era Aznar, cuyos socios políticos naturales - Berlusconi, Fini, Rauti- entroncaban «con los postulados del más rancio fascismo italiano». En este círculo el presidente se sentía cómodo y él ejecutaba «operaciones tan depravadas desde el punto de vista político como expulsar al PNV del partido Popular Europeo para hacerle un hueco a Berlusconi y su cuadrilla de fascistas. Esa es la deriva que espera a una Euskadi en manos de Aznar si el 13 de mayo no se le pone remedio» ${ }^{72}$.

Y lo que por su extensión podía parecer un análisis era una buena colección de insultos, que reservaba las alabanzas para el candidato nacionalista, su programa y único proyecto de libertad y de convivencia para el país. El autor, que llamaba a trabajar por el voto como él, que en una semana había «amarrado» 15 votos, incluso de residentes en Caracas y La Habana que vendrían expresamente a votar, decía que la cuña electoral del partido socialista era un «cubo de basura»; el senador Javier Rojo era un «bocazas desatado y agresivo»; TVE hacía campaña contra el nacionalismo y la Junta Electoral Central (la misma que había favorecido a la coalición nacionalista en la atribución de los espacios gratuitos), «brazo ejecutor del españolismo más rampante», lo negaba; el PSE estaba en situación mendicante, de maletero del ex ministro de Interior, y, juntamente con el PP, pondría al euskera en un museo, si estuviera en sus manos. Ni Fujimori ni Montesinos habrían organizado mejor el ataque al PNV-EA y los desprecios e insultos al nacionalismo vasco. «Crear una realidad virtual, unir nacionalismo con violencia, centrar los ataques en el PNV-EA y no en ETA, utilizar a Aznar a todas horas contra el Gobierno Vasco, silenciar las noticias positivas, desmesurar cualquier in-

71 Deia 29-4-2001 (9), «Redondo y Mayor ven en "Basta Ya" lo mejor de la sociedad vasca», J.C. Ibarra; (32), «¿Intelecto o política pura y dura?», Amaia Fano; (33), «Lo mejor de lo mejor», Juan Carlos Lotxaga; 30-4-2001 (16), «Los jinetes de Kazán», Antonio Alvarez Solís; (21), «Los idiomas no matan», Juan Carlos Latzaga; 1-5-2001 (26), «Quien ríe el último, ríe mejor», Amaia Fano, que denuncia los ataques en el Kursaal contra Madrazo, por tener la valentía de no sumarse a sus filas. Ver, también, Deia 9-5-2001, (30), «No fue un simple desliz», Xavier Lapitz, citado anteriormente.

72 Deia 3-5-2001 (32), «Los amigos italianos de Aznar», Kepa Bordegarai. 
conveniente y todo esto con el escudo protector de una Junta Electoral llena de hostilidad contra un nacionalismo al que hay que pasarle factura. Y luego dicen que recurramos al Tribunal Constitucional, árbitro casero elegido por ellos. Si esto es una democracia que venga Montesinos y lo certifique...» Quien todo esto escribía no tenía inconveniente en recordar, a propósito de una intervención del socialista Augusto Bebel en el Parlamento alemán por la que, al recibir una gran ovación de la derecha, exclamó aquello de «iqué habré dicho para que me aplauda esta canalla!» - la anécdota venía a cuento para llamar a reflexión a Redondo por los aplausos que recibía del PP-, que «nunca es excesiva la cautela, cuando se trata de hablar o de actuar para el público. La palabra suele ser voluble y a veces dice lo que no queremos decir» ${ }^{73}$.

El insulto y la autocomplacencia se unían a la demagogia (ya el anterior era un ejercicio de demagogia) en un artículo que tenía por objetivo la crítica del PP y, especialmente, Mayor Oreja y Carlos Iturgaiz. Comenzaba el artículo por manifestar su rechazo frontal de los debates electorales con diversos argumentos que culminaban en la afirmación de que pertenecían, sobre todo, a la cultura norteamericana, que, quizá, por su falta de experiencia histórica y por ser una sociedad tan hipócrita y falsificada, necesitaba la voz del predicador y el espectáculo de los discursos emocionales. Pero esto era Euskadi, «un viejo país donde tenemos una sana prevención con los charlatanes». Resultaba, además, que Mayor Oreja, «enemigo mortal del diálogo político y paladín de los silencios», quería ahora debates. La cosa sonaba a falso, hería y sangraba (el autor parece olvidar que la propuesta de debate, que saltó a la campaña con más fuerza, fue la de Ibarretxe), tanto más cuanto el debate era un espacio en vías de extinción en las televisiones - lo que había era del género de la telebasura, v.g. Javier Sardá, o del género de humor, el de José María Calleja en CNN+, que si hablaba del País Vasco llevaba a dos personas de la misma opinión españolista- y en la radio española, donde había sido substituido por la tertulia, que, salvo «la meritoria excepción de Iñaki Gabilondo», sólo transmitía agresividad personal e institucional, odio a lo vasco y papanatismo. En resumen, los debates no eran ninguna necesidad democrática y el autor sólo creería en los del PP «el día en que su elegido sea ese portento de la dialéctica euskaldun, ese campeón del argumento, ese Castelar del parlamentarismo autóctono, ese Cicerón de la retórica postmoderna, ese Fénix de los ingenios cuyas palabras embelesan y arrebatan, ese pico de oro apasionante llamado Carlos Iturgaiz» ${ }^{74}$.

73 Deia 6-5-2001 (36), «Dime quién te aplaude y te diré quién eres», Iñaki Anasagasti.

74 Deia 10-5-2001 (29), «De votos y debates», José Ramón Blázquez. 
Algunos de los supuestos argumentos recogidos más arriba —estrategia de confrontación con el nacionalismo para destruirlo, premisa de que el nacionalismo «democrático» era el responsable de ETA, abandono del consenso de la transición, frente popular-mediático-judicial, desaparición de los escrúpulos y de los argumentos jurídicos en la lucha contra el terrorismo, cruzada de insultos y calumnias contra el nacionalismo, ausencia de legitimación intelectual, centralismo, franquismo, abandono de los intereses vascos - se utilizaron, también, en comentarios con pretensiones de ser más que denuncias, escritos por nacionalistas e, incluso, por algún miembro del Partido Socialista y ex miembro del Partido comunista, cuyo lazo de unión fue la censura al Partido Popular y el poco rigor en la argumentación. El beneficiado de todo ello era, por lo menos, el nacionalismo de la coalición.

Parte de estos contenidos se daban en la descripción de la interpretación que en Madrid hacían de las elecciones: un referéndum, en el que había que «vencer, hundir, machacar y triturar al nacionalismo democrático». Las elecciones vascas se iban a desarrollar sin control político y con mínimos democráticos, y, mientras en Madrid se presentaban libros contra el PNV — violencia, sexo, antinacionalismo, cien mentiras, una portada con ikurriña-, no eran noticia varios «salvajes atentados» contra los batzokis de Elorrio y Portugalete. La campaña de Mayor Oreja era como las cruzadas, una campaña bien arropada. «Políticos europeos, víctimas del terrorismo, escritores agradecidos, intelectuales a la violeta, colectivos fantasmas, todo vale para decir lo bueno que es, lo pérfido del nacionalismo a quien hay que pilonar y el mundo idílico que hagan, sin decir cómo, y que nacerá el 13 de mayo. Acabará con ETA, pondrá al PNV-EA en su sitio, encarcelará a media humanidad, distribuirá entre La Rioja y Cantabria los fondos vascos, dejará a ETB en su sitio, permitirá a la gente sólo decir "egunon", valorará el inglés por encima del euskera y acabará con los mitos nacionalistas. San Jorge no lo haría mejor ante el dragón» ${ }^{75}$.

La estrategia hostil de los populares contra el nacionalismo era el obstáculo a la llamada a los líderes políticos a dialogar al día siguiente de las elecciones, recordando la petición en tal sentido que se hizo en la manifestación tras el asesinato de Lluch. El diálogo debería abordarlo quienquiera que alcanzara el gobierno vasco con todas las fuerzas que condenaran la violencia y los atentados, porque lo que querían saber

75 Deia 29-4-2001 (34), «Pasar el despacho de Ajuria Enea a Intxaurrondo», Iñaki Anasagasti. En el artículo «Ibarretxe eta kitto», de Mikel Atxaga, se pide el voto nacionalista para Ibarretxe. 
los vascos era cómo se iba a afrontar el problema de la violencia — percibido por españoles y vascos como el problema más preocupante- y qué capacidad de acuerdo existía entre las fuerzas democráticas. La política del diálogo debía sustituir a la estrategia de la tensión y confrontación con el nacionalismo que seguía el Partido Popular, cuya construcción teórica partía de la premisa de que el nacionalismo democrático vasco era el responsable último de la violencia de ETA, por lo que para acabar con ETA había que acabar en primer lugar con aquél. El articulista interpretaba que había sido el centro-derecha español el que con esta nueva estrategia se había alejado de la que siguió en la Transición, compartida por el PSOE y el PCE, de buscar un acuerdo con el nacionalismo, entendiendo que lo prioritario era el aislamiento social y político de ETA, estrategia que había permitido la aprobación del Estatuto de Gernika, la incorporación del PNV a las mayorías parlamentarias, el Pacto de Madrid y el de Ajuria Enea. Se había, pues, roto la unidad democrática y el consenso, por lo que urgía recuperar éste, al menos, en varias cuestiones: la prioridad de la violencia y el reconocimiento de que no existía una solución exclusivamente policial; el Estatuto como punto de encuentro; y la búsqueda del acomodo definitivo del nacionalismo en el edificio constitucional. Sería una buena noticia, concluía el autor, que se recuperasen el talante y los métodos utilizados en la Transición como se había recordado recientemente en una reunión de dirigentes y ministros de UCD con Jaime Mayor Oreja. ${ }^{76}$

La criminalización del nacionalismo y el olvido de la independencia institucional se usaban en otro escrito que comentaba el homenaje a Mayor Oreja celebrado en Madrid, al que asistieron miembros del gobierno, jueces, fiscales, el Defensor del Pueblo — «representantes de poderes constitucionales, obligatoriamente independientes entre sí»y empresarios, banqueros, dueños de los medios de comunicación próximos al Partido Popular - representantes de poderes «reales y actuantes en la mal llamada sociedad civil». Era, también, un acto de apoyo electoral a Mayor Oreja, que, a pesar de la «división acorazada» mediática, había dejado tras su marcha del ministerio de seguridad «más borrones que escritura, más nubes que claros». A pesar de esto, lo que ahora interesaba era que ganase en el País Vasco, por encima de todo,

76 Deia 30-4-2001 (16), «Hablad, hablad, hablad», Enrique Curiel. El análisis ignora la responsabilidad del mal llamado nacionalismo democrático — todos los partidos tienen nombre- en la ruptura de la unidad democrática con el pacto de Lizarra y la vierte exclusivamente sobre el Partido Popular. Las condiciones del consenso muestran el idealismo de la propuesta. Toda la crítica al PNV se reduce a pedirle explicaciones sobre por qué no rompió con $\mathrm{EH}$ al día siguiente del primer atentado tras la tregua o por qué no desveló que tal pacto impedía el acceso de los socialistas al gobierno de Ibarretxe. 
a cualquier precio, incluso a costa de las formas. «Todos contra el nacionalismo vasco a quien se criminaliza». Esto suponía, según el autor, seguir la dinámica dicotomizadora de ETA y abandonar la actitud seguida durante años de no considerar culpables de delito a los integrantes del entorno de ETA - miembros de HB y gestoras, que aplaudían a los asesinos, y jaleadores y sostenedores del terrorismo- y la diferenciación entre la delincuencia del terror y la acción política independentista. Con la llegada del PP habían desaparecido los escrúpulos y los argumentos anteriormente antijurídicos habían dejado de serlo y, en consecuencia, ETA no era ya sólo los comandos, sino los integrados en organizaciones satélites al amparo del Estado democrático de derecho. Esta había sido siempre la interpretación de los ministros de Interior, pero no la del poder judicial y mediático. Había que explicar cómo podía ser posible este cambio, si el ordenamiento jurídico era el mismo - y el giro estratégico del PNV había sido sólo un error-, y por qué era «legítimo saltarse las barreras y olvidar la debida independencia institucional para juntar todas las fuerzas en torno a un proyecto político de derechas». Se trataba, simplemente, de reescribir la historia imponiendo el silencio, "la espiral del silencio" que acompaña a todas las grandes campañas mediático-judiciales con efectos políticos avasalladores ${ }^{77}$.

En la misma dirección se escribió un artículo propagandístico y esperpéntico en el que la «credencia», que fue la comunidad medieval de campesinos, artesanos y asalariados, una forma de autogobierno libre e independiente de los señores feudales, sirvió para presentar a los populares y al frente judicial en contra de la libertad e independencia - la credencia vasca-, de la que estaba enamorada la mayoría del pueblo vasco y por la que éste «luchará y después descansará». Así como los cruzados feudales de la cuarta cruzada se lanzaron contra los comuneros italianos, así una nueva cruzada estaba actuando contra los comuneros actuales, sus amigos y sus feudos, los nuevos herejes. «Contra ellos no hay mentira suficiente, difamación excesiva, disparate bastante o exceso reprobable». Un ejemplo era el famoso debate. Otro lo era la actuación del frente judicial - cierre pretoriano de Ardi Beltza, encarcelamiento de Pepe Rei con grave riesgo para su vida y anuncios de la eliminación de Haika y más tarde de EH y todo el MLNV. Así se llegará al «paraíso español de los cruzados. No hay más dios que Aznar y Mayor es su profeta». Sólo había una patria, una nación y una lengua, nunca impuesta, aunque muchos, por negarse a hablarla, encontraron la

77 Deia 3-4-2001 (22), «La división acorazada», Joaquín Leguina. 
muerte o la cárcel. «Cuando los insultos y las calumnias contra el nacionalismo vasco parecían insuperables, de nuevo hemos vuelto a comprobar que todo es superable» ${ }^{78}$.

La supuesta pretensión del PP de encontrar entre los pensadores políticos españoles algún padrinazgo que permitiese avalar la democracia de sus planteamientos ideológicos y que ocultase «el vergonzante sustrato franquista de sus fundadores» fue tema de un comentario. Tal intelectual parecía ser Ortega, sólo que era utilizado de manera poco honesta y sincera, ya que de él se tomaba su proyecto de vida en común, pero se dejaba de lado su crítica al uso particularista del poder central - particularismo en sentido de utilizar el poder para fines privados-, que estaba en el origen, según Ortega, de la eclosión de los particularismos catalán y vasco. La solución del problema nacional no estaba en ganar las elecciones a vascos y catalanes. El problema estaba en el centro. El autor aplicaba el caso a Mayor Oreja, calificándolo de «patriota con cabeza de cartón» tal como Ortega llamó los políticos de su época, por creer que ahora «el problema de su proyecto nacional español radica en ganar las elecciones autonómicas vascas y catalanas» 79 .

El último comentario de este apartado concluía, dirigiéndose a los gobernantes españoles «centralistas», que «su generosidad, y su españolismo de embudo, además de impuesto, nos sale carísimo». La ocasión del comentario eran las declaraciones de Aznar y Areilza en el sentido de que Euskadi tenía una de las autonomías mayores del mundo y que el gobierno central estaba acostumbrado a sacar las castañas del fuego a cada una de las autonomías. En el escrito se negaba que Euska-

78 Deia 4-5-2001 (31), «La credencia vasca», Joaquín Navarro.

79 Deia 2-5-2001 (31), «Patriotas con cabeza de cartón», Josu Erkoreka. No es aceptable la explicación o sugerencia —en el supuesto de que el artículo tenga algo de lógica- de que el problema que planteaba el PNV, el del soberanismo, autoderminación o independentismo, tuviese por origen la patrimonialización del uso del poder central, lo que Ortega llamaba particularismo. La idea de una democracia corrompida como justificación del separatismo nacionalista no era el fundamento de las pretensiones nacionalistas, por más que Arzalluz y Anasagasti insistieran en la poca calidad de la democracia española. Este argumento se usaba para desprestigiar al adversario y, en todo caso, para completar la justificación de las pretensiones «naturales» del nacionalismo, basadas en la idea de nación, pueblo natural, que, en su opinión, eran el origen de su legitimidad. Esta reflexión es, además, sorda a la acusación del uso clientelar del poder autonómico por parte de los nacionalismos periféricos y regionalismos. Por otra parte, la afirmación de que al observador objetivo le resulta difícil discernir si los defensores de la idea de España como proyecto común tuvieron (se cita a Oriol, Urkijo, Ibarra, Bilbao, Oreja, Iturmendi) a este proyecto como más sugestivo que el de utilizarlo para su progreso personal, olvida que no se puede entender la creación de la nación sin los intereses y valores particulares y sociales que la acompañan o motivan, especialmente, los de la burguesía, aquí, en Francia y en cualquier otro país. Lo contrario sería una interpretación idealista de la historia y de la realidad política y social. 
di tuviera la autonomía de la que hablaba Aznar basándose en dos criterios. El primero tenía en cuenta la representación directa ante la UE en los temas que afectaban a las competencias o intereses de los entes subestatales y, además, la representación interna en la toma de decisiones dentro de cada Estado. Mientras Euskadi no tenía representación en Europa, sí la tenían, en cambio, escoceses, flamencos, valones, diferentes länder alemanes y austriacos. Lo mismo ocurría en cuanto a la representación interna. En este sentido, la Conferencia Sectorial de las Comunidades Autónomas carecía de todo valor, según el autor. El segundo criterio tenía en cuenta que muchas competencias (que no se concretaban) exclusivas de las Comunidades Autónomas habían pasado al ámbito comunitario y era el Estado el que las ejercía. Ello suponía una recuperación por parte de éste de competencias que perdían las autonomías. En cuanto a la defensa de las autonomías por el Estado se recordaban (sin más consideraciones) los 75 recursos interpuestos por el Gobierno de Madrid contra medidas fiscales vascas o el recurso contra la delegación del Gobierno Vasco en Bruselas. La conclusión era que el Estado español era de estructura descentralizada, pero de mentalidad centralizadora que, además de no reconocer el derecho del País Vasco a ejercer la autodeterminación, no permitía la representación en Europa perjudicando así los intereses vascos. «Por favor, señores gobernantes españoles, les pedimos que no sean generosos con nosotros» ${ }^{80}$.

La mayor parte de los textos breves relativos a la coalición nacionalista manifestó una coincidencia total con sus afirmaciones básicas de campaña sin ningún tipo de innovación. Los colaboradores apoyaron mediante su repetición lo que en las páginas del periódico aparece como información de las manifestaciones de los políticos. La identidad — que ocupó casi el 34\% — fue, en general, absoluta. Y como no hubo añadidura a las tesis nacionalistas, sus afirmaciones vinieron acompañadas de la crítica o denuncia de populares y socialistas como

80 Deia 12-5-2001 (29), «Generosidad y centralismo», Gorka Knörr Borrás. El escrito, en la línea de la campaña nacionalista, que de ninguna manera puede considerarse un análisis - lo mismo cabe decir de los anteriores artículos - es extravagante por la afirmación de que el autogobierno vasco era caro para los vascos («nos») por culpa del españolismo centralista y por unir el centralismo con la negación del supuesto derecho de autodeterminación, lo que convertía a todos los Estados del mundo, por disparate político-literario, en centralistas, ya que ninguno lo reconocía. Por otra parte, es insuficiente valorar el autogobierno basándose únicamente en los criterios manejados y, mucho menos, si no se aclara el significado de «representación directa», aunque tales criterios eran también básicos y debían tenerse en cuenta, especialmente el que se refería a la pérdida de competencias exclusivas. Por último, no se puede citar los recursos, sin mayor rigor de explicación, como negación de la defensa de la autonomía ante la UE. 
defensa del nacionalismo. Esto ocurrió al hablar de los resultados electorales previsibles, del diálogo, de las candidaturas a lehendakari y de los objetivos de los partidos. Sólo hubo palabras de alabanza, si se exceptúa a Madrazo, para Ibarretxe y únicamente se aclararon los objetivos nacionalistas: conseguir que los vascos pudiesen decidir su futuro sin límites ni presiones en el caso del PNV-EA o la construcción nacional de EH. Hasta los términos usados por los candidatos, se escribía, identificaban a los mismos. Frente al «miedo» o «derrota» o «no» de Mayor y Redondo, estaban las palabras de Ibarretxe «construir», «colaborar» $\mathrm{y}$ «dialogar» para la paz ${ }^{81}$.

La identificación con la campaña de la coalición incluyó la felicitación por la presencia de un equipo vasco en el Tour; la petición expresa o tácita del voto para la coalición; la adulación a Ibarretxe; el apoyo a la estrategia nacionalista ante la violencia, Lizarra incluido; el reconocimiento de la virtud nacionalista ante la calumnia; la consideración del programa nacionalista como proyecto de libertad; la jactancia por el éxito económico y el bienestar, mayores que en «el resto del Estado»; la denuncia de la conspiración cuasi universal contra el nacionalismo democrático; la instrumentalización del terrorismo de ETA para atacar al PNV; la presentación del PNV en el centro de las dos violencias, la que puede matar y la que puede detener; la dramatización del momento electoral, el ser o no ser de la construcción o aniquilación de Euskal Herria; y la denuncia del miedo, antidemocracia e intromisiones del gobierno, jueces, kale borroka y ETA en la campaña ${ }^{82}$.

81 Deia 13-5-2001 (29), «Tuve un compañero de pupitre apellidado Fernández Savater», Iñaki Anasagasti; Deia 1-5-2001 (18), «La guerra civil de Fernando Savater», Emilio Olavarria Muñoz; Deia 12-5-2001 (23), «Hoy toca silencio a la clase política», José Luis Iturrieta; Deia 3-5-2001 (20), «El elector y sus derechos», Patxi Zabaleta;

Deia 29-4-2001 (9), «Redondo y Mayor ven en "Basta Ya" lo mejor de la sociedad vasca», J.C. Ibarra; (32), «iIntelecto o política pura y dura?», Amaia Fano; (33), «Lo mejor de lo mejor», Juan Carlos Lotxaga; 30-4-2001 (16), «Los jinetes de Kazán», Antonio Alvarez Solís; (21), «Los idiomas no matan», Juan Carlos Latzaga; 1-5-2001 (26), «Quien ríe el último, ríe mejor», Amaia Fano, que denuncia los ataques en el Kursaal contra Madrazo, por tener la valentía de no sumarse a sus filas. Ver, también, Deia 9-5-2001, (30), «No fue un simple desliz», Xavier Lapitz, citado anteriormente; Deia 3-5-2001 (32), «Los amigos italianos de Aznar», Kepa Bordegarai; Deia 6-5-2001 (36), «Dime quién te aplaude y te diré quién eres», Iñaki Anasagasti; Deia 10-5-2001 (29), «De votos y debates», José Ramón Blázquez; Deia 29-4-2001 (34), «Pasar el despacho de Ajuria Enea a Intxaurrondo», Iñaki Anasagasti; Deia 30-4-2001 (16), «Hablad, hablad, hablad», Enrique Curiel; Deia 3-4-2001 (22), «La división acorazada», Joaquín Leguina; Deia 4-5-2001 (31), «La credencia vasca», Joaquín Navarro; Deia 2-5-2001 (31), «Patriotas con cabeza de cartón», Josu Erkoreka; Deia 12-5-2001 (29), «Generosidad y centralismo», Gorka Knörr Borrás.

82 Ver todos estos puntos en Deia 27-4-2001 (2), «¿Quién habla de que los conflictos son iguales?», Juan José Baños; (11), «Cinco tipos de corredor distintos disputan ya la 
La estrategia del periódico fue tan semejante a la de la campaña del PNV-EA que hasta los artículos, cuyos títulos o caracterización como comentarios de opinión sugerían una profundización en la exposición de la naturaleza o legitimidad del nacionalismo, su papel político y social, sus estrategias o su modernización, se redujeron, salvo alguna muy contada excepción, a presentarlo perseguido y acorralado por una especie de confabulación universal donde la mirada se ponía sobre los «otros» a través de la denuncia o la acusación. La comunidad nacionalista quedaba como el baluarte defensivo a la que se apoyaba incondicionalmente con una aceptación acrítica de los objetivos, opciones, estrategias y supuestos éxitos, dando por obvio y demostrado cuanto se refería a la fundamentación del nacionalismo y su razón de ser.

Pero no todo lo que se escribió en Deia fue aplauso para el PNV y EA. Aunque poco, hubo veladas desconfianzas, reconocimiento de ineficacias y errores y advertencias juiciosas hechas por nacionalistas. En este último sentido y con ocasión de exponer las convulsiones internas que el posible desalojo del Gobierno por populares y socialistas podía provocar en la coalición PNV-EA, Deia publicó un análisis crítico, tal vez el único, sobre el PNV. Decía el artículo que a los nacionalistas del PNV les resultaba complicada la conjunción de 20 años de gobierno con el fracaso de la fórmula de Lizarra «paz por objetivos políticos». Esta había carecido del entusiasmo de la mayoría del «Pueblo Vasco», para el que la paz era ausencia de violencia - no la paz duradera, consecuencia de la construcción nacional - y la legitimidad de una profunda transformación de las instituciones tenía que estar fundamentada en mayorías cualificadas. Lizarra no respetó el principio de realidad so-

carrera del 13-M», J.C. Ibarra; 28-4-2001 (11), «Políticos abocados a la palabra tarde o temprano», J.C. Ibarra; 29-4-2001 (32), «Ibarretxe eta kitto», Mikel Atxaga; 30-4-2001 (2), «De algunos osos entre la mofa y la solemnidad», Juan José Baños; (7), «Los líderes "nacionales" levantan los actos del PP y PSE», J.C. Ibarra; (16), «Los jinetes de Kazán», Antonio Alvarez Solís; 1-5-2001 (30), «Los obispos y la paz», José Ramón Scheifler; 3-5-2001 (2), «Un equipo vasco en el tour de las estrellas», Juan José Baños; 4-5-2001 (30), «El barullo electoral», Gabriel Mariscal; 5-5-2001 (32), «Leopoldo Barrera y el euskera de Ibarretxe», Martín de Arribillaga; 6-5-2001 (19), «Carta abierta al Sr. Mayor Oreja», Koldo Aldai; (36), «Dime quien te aplaude y te diré quién eres», Iñaki Anasagasti; 7-5-2001 (26), «La gran mentira, el gran error», José Ramón Scheifler; 9-5-2001 (32), «El 13 de mayo, elección», Luis M. ${ }^{a}$ Retolaza y Ramón Labaien; 12-5-2001 (2), «Imaginemos que es hoy cuando regresa Tito», Juan José Baños; (9), «La elección es sencilla, pese a lo complejo del panorama», J.C. Ibarra; (26), «Un rápido resumen de mensajes», Xavier Lapitz; «Apuntes para una reflexión», Amaia Fano, a la que pertenecen los entrecomillados del texto; (29), «Un debate clarificador», José Ignacio Bajo; 13-5-2001 (2), «Que las urnas huelan a vida, diálogo, paz y libertad», Juan José Baños; (13), «Porcentajes», José Uriarte; (26), «La ¿nueva? derecha europea», Xavier Lapitz. El deseo de Amaia Fano, (29), «A unas horas del desenlace», de que ganara el menos malo fue una excepción. 
cial y, en la medida en que se persistiera en lo mismo, los resultados serían similares o, incluso, peores, pues estas elecciones serían las últimas en las que el PNV-EA obtendría votos provenientes de la «emoción que origina lo que está en juego unida a la ira que causa el ensañamiento del adversario». Para las siguientes elecciones el nacionalismo democrático debía enfrentarse con estas cuestiones de fondo: envejecimiento de su cuerpo electoral, adaptación de su ideario a la realidad, «pérdida del carácter épico de su identidad», modelo definitivo político en relación a España y Francia dentro de UE y «resolución de las relaciones socio-políticas en el trato dado como "hijos pródigos" a quienes no resultan ser otra cosa que utilitaristas antisistema a la búsqueda de compañeros de viaje hasta donde ellos determinen». El cambio del PNV debía consistir, pues, en actuar en la construcción nacional desde las instituciones vigentes, a pesar de ETA y EH, excluyendo reivindicaciones comunes con el MLNV, mientras ETA no abandonara «la lucha armada». El resultado de las elecciones, por otra parte, sería el de una realidad plural en las identidades, más exacerbada en lo político, con un papel más importante a jugar por el Parlamento y con una sociedad demandando soluciones, pero no a cualquier precio ${ }^{83}$.

El criterio sobre ETA se puso especialmente de manifiesto después del asesinato cometido en Zaragoza, siendo esto, tal vez, lo más sobresaliente. Hasta nueve comentarios, entre artículos y breves, aparecieron en un mismo día. Casi todos contienen el rechazo y condena inequívoca de ETA de manera expresa. Y, en los menos, la condena tácita es evidente. Otros comentarios, anteriores y posteriores a tal unanimidad, coinciden en expresar, además del dolor, semejante valoración. El espacio dedicado, de todos modos, por Deia a este apartado no alcanzó el $7 \%{ }^{84}$.

83 Deia 9-5-2001 (20), «El cambio, iqué cambio!», Txema Montero. Ver, también, Deia 10-5-2001, (18), «Los árboles y el bosque», Kepa Landa; Deia 4-5-2001 (18), «Limpios de pecado», Pello Salaburu. Joaquín Leguina, Enrique Curiel y Xavier Gurrutxaga (éste El Correo) también hablaron de errores y silencios del PNV; ver artículos citados anteriormente. Txema Montero habló de fracaso de Lizarra, tal como se recoge en el siguiente comentario.

${ }^{84}$ Deia 10-5-2001 (30), «La conferencia episcopal», Fernando Sebastián; 7-5-2001 (2), «Los señores del terror no están en campaña», J.J. Baños; Deia 7-5-2001 (2), «Los señores del terror no están en campaña», Juan José Baños Loinaz; (13), «Una mañana de encuestas y una tarde de tragedia», Javier Velilla; 8-5-2001 (2), «El respeto que se debe a un recién fallecido», Juan José Baños Loinaz; (30), «Bai, bakea behar dugu», Amaia Fano; (11), «La fractura política marcó el día después del atentado», J.C. Ibarra; (22), «Si Dios lo permite, que haya un gobierno constitucional», Paco Gandoy; (17), «ETA intenta marcar el ritmo», José Luis Uriz Iglesias; (16), «Que se vayan», Joaquín Navarro Esteban; (18), «ETA no quiere puentes», Enrique Curiel; (17), «Su única vida», Ramón Mugica; (26), «La gran mentira, el gran error», José Ramón Scheifler; 11-5-2001 (31), «El día después», Mikel 
No cabe hablar de análisis en los comentarios de Gara, salvo alguna excepción. Son básicamente denuncias y acusaciones contra todos aquellos que se oponen, en primer lugar, a la construcción nacional vasca $y$, en segundo lugar, a la única fuerza comprometida con tal tarea, la izquierda abertzale. Esta denuncia afecta al Partido Popular, al Partido Socialista, al Partido Nacionalista, a los medios de comunicación, a Basta Ya, a la Iglesia Católica, a los órganos y fuerzas de seguridad del Estado, a la Asociación Mundial de periódicos, a Sindicatos e, incluso, a Elkarri. Todos formarían objetivamente el frente nacional español, aunque con naturaleza distinta: responsables, ejecutores, colaboradores, inactivos y desorientados. Por ello, la crítica y denuncia es, en ocasiones —el caso más claro es el del PNV_- parte de una llamada a la integración de las fuerzas nacionalistas. No obstante todo lo dicho, se percibe en determinados textos la sensación de que el experimento nacionalista no funcionaba y que la desorientación afectaba, incluso, a la misma izquierda abertzale. El total dedicado a este conglomerado es el 62,5\% de lo escrito sobre partidos; el 35\% para los partidos constitucionales y afines, y el resto, prácticamente, para el PNV.

La denuncia abarca la identificación del nacionalismo español con el fascismo, la persecución de la izquierda aberztale y la colaboración del PNV; el ayuntamiento de la derecha, gran burguesía, intelectualidad y prensa españolas; la actitud contraria de la Iglesia ante el llamado caso vasco; y los ataques al euskera. Determinadas caracterizaciones del «enemigo» y la utilización de ciertos términos parecen querer evocar vagamente algo que fue casi marginado en la campaña y en la prensa, la condición revolucionaria y social del movimiento radical ${ }^{85}$.

Urkiola García. El rechazo de ETA por razones éticas y pragmático-políticas aparece en Deia 11-5-2001 (30), X «iOye ETA mi aflicción!», Angel Gaminde; Deia 28-4-2001 (11), «Políticos abocados a la palabra tarde o temprano», J.C. Ibarra; 8-5-2001 (30), «Con la fuerza de los votos», Xavier Lapitz; 9-5-2001 (20), «El cambio, ¡qué cambio!», Txema Montero; 9-5-2001 (32), «El 13 de mayo, elección», Luis María Retolaza y Ramón Labaien. No hay que olvidar que la mayor parte de los comentarios sobre Euskal Herritarrok se dieron con ocasión de la formación de gobierno y, en concreto, ante la cuestión de si el PNV gobernaría o no con el apoyo de los votos de EH. El tema está tratado y allá me remito. Milagros Rubio, parlamentaria navarra de Batzarre, en Deia 5-5-2001 (19), dio su versión de partido en «Elecciones en la CAV en la época del postLizarra» en Deia 28-4-2001 (11).

85 Ver: Gara 6-5-2001 (8), «Alicias sin salida», José Mari Esparza Zabalegi; Gara 6-52001 (11), «Sarcasmos», Javier Salutregi Mentxaka; Gara 29-4-2001 (13), «Todo vale», Javier Salutregi Mentxaka; Gara 2-5-2001 (11), «La alarma está encendida en nuestras casas», Juan Antonio Madariaga Erezuma; Gara 4-5-2001 (10), «Libertad de prensa y libertad de expresión», Iñaki Iriondo; «Hauteskundeetako aforismoak», Edorta Jiménez; Gara 2-5-2001 (11), «Su libertad y canibalismo», Iñaki Gil de San Vicente; Gara 5-5-2001 (11), «El País cumple 25 años», Víctor Moreno; En Gara 4-5-2001 (11), «Dormir moscas», Kepa Ibarra; Gara 7-5-2001 (11), «El Vaticano siempre estuvo y está con el poder», Juan 
El esquema de interpretación de la izquierda abertzale, coincidente con el de la coalición nacionalista, como ya se ha visto a lo largo del trabajo, es el propio de unas premisas que interpretan la realidad a partir de la categoría nacional. Según esto, las elecciones son la lucha entre dos nacionalismos, en este caso, nacionalismo español y nacionalismo vasco. Ante tal planteamiento sólo cabe estar en uno de los bandos. Pues bien, para los escritores del periódico Gara, la coalición nacionalista, especialmente el PNV, rompía este esquema, ya que parecía estar en un nacionalismo, pero actuaba con otro. Era la singularidad del colaboracionismo. Y esto se manifestaba lo mismo ante la formación del gobierno de la siguiente legislatura que ante el euskera o cualquier otra cuestión $^{86}$.

Con tales valoraciones no podía hacerse otra cosa que llamar a la izquierda abertzale al compromiso como único motor para la liberación nacional, ya que el PNV no utilizaría para la construcción nacional el «montonazo de votos miedosos que le han llovido de gente abertzale» ${ }^{87}$.

Nada se dice sobre ETA, a excepción de alguna alusión expresa o velada hecha con ocasión de analizar la política de Euskal Herritarrok. Y lo escrito sobre EH gira en torno a la orientación del voto, que casi siempre de una manera explícita se pide para la izquierda aberztale, apoyándose en su radical nacionalismo o en su política de unidad, soberanía y libertad para el pueblo vasco. Casi el 38\% de los textos giraron en torno a Euskal Herritarrok ${ }^{88}$.

José Arregi Azpeitia; «Paleolitikotan ote geunden 1976an?», de Mikel Aramendi; Gara 85-2001 (8), «¿Alguien quiere mentira mejor?», Txotxe Andueza; «La penúltima sobre nacionalismos» (IV), Jon Odriozola; (11), «Del euskera, los ornitorrincos y la nalga del ex ministro», Xabier Kintana; Gara 9-5-2001 (10), «Euskera, excusas y reparaciones», Jabi Otsoa de Alda; Gara 5-5-2001 (10), «De nuevo, el inefable Fraga», Josu Cereceda.

86 Ver Gara 2-5-2001 (15), «Retener Ajuria Enea, obsesión para PNV-EA ante su enésima encrucijada», Ramón Sola (la idea sería repetida en muchas ocasiones); Gara 30-4-2001 (6), «Sólo la vida vence al mundo», Alicia Sturtze; 3-5-2001 (10), «Sano regionalismo que complace a Madrid», Jon Urrujulegi; Gara 30-4-2001 (6), «La declaración del rey de España es una soberana mentira», Inazio Agirre Arregi; Gara 11-5-2001 (8), «Mirar el retrovisor», Iñaki Iriondo; Gara 11-5-2001 (8), «Mirar el retrovisor», Iñaki Iriondo; (10), «Gazteok, indarra eta borroka», Gari Mujika. Gara también recogía el artículo «13-M, lo que es y lo que no es», que publicaba el periódico Deia y que se recoge en este trabajo; Gara 12-5-2001 (8), «País Vasco-Español versus Euskal Herria», Xarlo Etxezaharreta; (9), «Qué dice el que calla cuando calla», Jorge Txokarro; «Muchos recursos, pocos debates y una deseada llave» (17), de Alazne Basáñez, era, más que otra cosa, un resumen descriptivo, muy elemental, de la campaña de los partidos.

87 Gara 14-5-2001 (8), «Sigamos dirigiendo el camino», Alizia Sturtze.

88 Ver Gara 27-4-2001 (8), «Por favor, deja de llorar», Iñaki Iriondo; 3-5-2001 (10), «Sano regionalismo que complace a Madrid», Jon Urrujulegi; 5-5-2001 (8), «Mendebaldeko abertzaleen botoa», Gaizka Aranguren; «Fikzioren denbora euskal politikan», Paco 
Sólo un comentario, tal vez el único análisis de Gara, que trataba de explicar las causas del desánimo y dudas sobre la utilidad y orientación del voto en amplios sectores nacionalistas y, sobre todo, en la izquierda abertzale, se salió de este esquema, aunque siempre dentro de una argumentación nacionalista. Era una explicación inusual en este periódico, que, además y básicamente, analizaba el problema del voto dirigido al PNV-EA como voto útil para evitar el triunfo de Mayor. Las razones objetivas o causas del desánimo y desorientación eran: la vuelta a «lucha armada» de ETA, sobre la que el autor vertía un juicio negativo al decir que, si se obstinaba en jugar a las vanguardias con análisis políticos del siglo XIX, obligaría — se ha de entender que a los abertzales, él incluido-, a actuar eternamente a la defensiva, cuando había otras posibilidades; la indefinición y «la política de multipartido del PNV» con los adscritos al nacionalismo por su condición de caballo ganador; el avance de las fuerzas españolistas con su discurso del miedo y el rechazo del terrorismo; la incapacidad de la izquierda abertzale de ofrecer un proyecto no condicionado para el $80 \%$ de la población; y la eterna división en el nacionalismo entre la izquierda abertzale y el PNV — «nosotros somos mejores, ya que nos pringamos y nuestros objetivos están plenamente definidos, sin ambigüedades (la izquierda abertzale); nosotros somos más, somos quienes gobernamos, y nada se puede hacer sin nosotros (el PNV)». Dada la ofensiva PP-PSOE, no era recomendable la abstención. Votar a PNV-EA para mostrar el desacuerdo con ETA sería un castigo a la opción soberanista, ya que ETA tomaba sus decisiones al margen de su utilidad para los votos de EH. Votar PNV-EA para evitar el triunfo de Mayor no permitiría alcanzar la mayoría absoluta; por otra parte, la mayoría relativa la alcanzaría sin tales votos; sólo aportaría dos o tres escaños más a costa de EH, lo cual podría repercutir en la orientación del PNV, no precisamente a favor del nacionalismo, y facilitar, por una izquierda debilitada, la hipotética ilegalización — «y por hoy factible»— de EH por parte del «Gobierno-Garzón». En resumen, — «ondo pensatu eta honetan bai, kontuz»-que cada uno votase según su sensibilidad lo mejor para Euskal Herria, «porque sólo así su voto tendrá al menos la utilidad de mostrarnos lo que hay» ${ }^{89}$.

Aristi. Ver, también, 10-5-2001 (8), «“Chiapas 2000”», Jesús Valencia, donde, además, se cae en el infantilismo de comparar Chiapas con Euskadi.

89 Gara 9-5-2001 (11), «13-M, retrato colectivo», Eneko Herran Lekunberri. El comienzo del artículo insiste en la visión del PNV desarrollada en este apartado. Ver, también, Gara 9-5-2001 (10), «La "utilidad" de los votos», Iker Gallastegi; Gara 10-5-2001 (10), «Un voto para la soberanía y la paz», Rafa Díez, Itziar Lopategi, Ainhoa Etxaide; Gara 135-2001 (11) «Del voto al pacto», Javier Salutregi Mentxaka; (8), «Botoa emateko, pakete osoa eta itxia hartu behar», Laura Mintegi. 


\section{Conclusiones}

El objetivo de este trabajo era analizar el papel de la prensa ante el discurso de legitimación de los partidos nacionalistas vascos. Supuestos los contenidos básicos de las campañas de los partidos políticos, las fuentes utilizadas permiten concluir los siguientes puntos:

1. La línea editorial de Deia confirmó la versión del PNV de que la sociedad vasca - y el mismo PNV - se encontraba sometida a la violencia de ETA y a la calumnia e injusticia de populares y socialistas. Salvarla de esta situación era el objetivo de la coalición nacionalista. Este encubrimiento de la naturaleza de los problemas se reforzaba con la explícita defensa de la campaña como debate electoral sobre la administración de las cosas y con la genérica explicación de la violencia como problema mundial. Gara, por su parte, apoyó la interpretación del enfrentamiento entre nacionalismos, denunciando la violencia de los Estados y exigiendo soluciones políticas para la violencia de ETA.

2. Fueron las colaboraciones de estos dos periódicos las que aludieron al supuesto fundamento del nacionalismo, la nación natural, a través de la ideología del derecho natural predemocrático y del sociobiologismo, repitiendo uno de los errores substanciales del sistema nacionalista de creencias, el de que el mundo está dividido en grupos nacionales o pueblos naturales - los sujetos de la historia - y que a cada uno de ellos corresponde la soberanía. En el caso de Gara, que señalaba a la lengua como el fundamento del pueblo (la misma idea aparece en Deia), hasta la violencia sería una de las consecuencias de la opresión de un pueblo sociobiológicamente constituido. El problema, pues, de la sociedad vasca, era el de la satisfacción del derecho a la vida y libertad en igualdad del pueblo vasco mediante la soberanía de Euskal Herria. La acumulación de votos para esta causa era la cuestión electoral y cada periódico la identificó con sus respectivas siglas políticas. Deia, que identificaba al pueblo vasco y la causa nacional con el PNV, hizo coincidir el problema vasco y la lucha contra la libertad de un pueblo con la pretensión de destrucción del nacionalismo democrático a base de su criminalización y culpabilización. La defensa de gobiernos mixtos o de concentración de algunos comentaristas no nacionalistas fue un postizo que no encajaba con las premisas teóricas ni estratégicas de la coalición.

A partir de este esquema ideológico, los partidos políticos PP y PSE, las asociaciones y los medios de comunicación favorables a sus objetivos fueron considerados por la prensa nacionalista la encarnación 
circunstancial del españolismo contra el vasquismo, la gran cruzada del nacionalismo español contra la nación vasca, el fascismo contra la libertad y la democracia, la persecución del vasco y de lo vasco. El miedo en Euskadi era, en buena medida, su invención.

Las diferencias entre Deia y Gara afectaron al apoyo a las campañas de la coalición y de $\mathrm{EH}$, respectivamente, y a las condenas y rechazos, el primero de ETA, especialmente a partir del asesinato, y el segundo, del PNV por su oposición a la construcción nacional y por su obsesión de poder. La identificación con la propaganda y mensajes de sus respectivos partidos fue total y, salvo dos incomprensibles y rarísimas excepciones, la homogeneidad de opinión fue pétrea. El recurso expreso o tácito al esencialismo e ideologismo fue común en los comentaristas orgánicos de la prensa nacionalista. También fue común la pobreza intelectual. De una manera exagerada Deia incluyó el insulto personal entre sus argumentos de campaña. La presencia de colaboradores no nacionalistas estuvo orientada a criticar y censurar al Partido Popular.

3. La pretensión de legitimación a través de este sistema dogmático de creencias fue contestada desde dos vertientes por la prensa de $E l$ Correo, El Mundo y El País: la de la realidad de la sociedad vasca y de la campaña electoral, trabajo hecho tanto por los editoriales como por los análisis, y la de la teoría, desarrollada por comentaristas y analistas. En la primera se destacó la incompatibilidad entre el nacionalismo, entendido como se ha dicho en este trabajo, y la sociedad vasca, tarea fundamentalmente realizada por los editoriales de El Correo. El muy grave problema vasco era el de la sociedad vasca, entendida como sociedad de ciudadanos, que afectaba al disfrute de los derechos fundamentales, al deterioro de las instituciones políticas y a la conciencia colectiva falsa, esquizofrénica y satisfecha. La causa estaba en el terrorismo de ETA y en la responsabilidad del PNV por su desmesura, apología de la barbarie, pretensiones de homogeneización, soberanismo, etnocentrismo, tibieza contra la violencia y aceptación de la separación entre los sometidos al terror y los otros como normalidad. El nacionalismo vasco, invención de la dirección de los partidos sin suficiente apoyo social - punto en el que coincidían El Correo y El Mundo-, se contradecía con la sociedad vasca plural. La cuestión electoral -elemento común a todos estos periódicos - consistía en la posibilidad de la alternancia y de su incidencia contra ETA y a favor de la libertad. Sin embargo, si se exceptúa a El Mundo, no hubo un explícito apoyo a la coalición de gobierno entre PP y PSE. La alternativa electoral estaba en elegir entre la razón y la superchería, identificada ésta más bien con ETA y la violencia. 
En la segunda, los análisis resaltaron la incompatibilidad del concepto natural de pueblo vasco y derechos preconstitucionales con la democracia y el liberalismo, y la contradicción entre único y natural pueblo vasco y sociedad plural. Salvo en muy contados casos en los que se utiliza el concepto histórico de nación española, los argumentos contra el nacionalismo primordialista, esencialista y etnicista vasco - al que se consideraba en buena medida creado y alimentado por la violenciahablaban de ruptura de la solidaridad, múltiple disfuncionalidad, antidemocracia, antiliberalismo y anacronismo de conceptos como los de patria, pueblo y etnicidad.

La naturaleza del problema real del país la describieron en términos de fractura de la sociedad vasca; división política, cultural, ideológica y emocional entre nacionalistas y no nacionalistas; ruptura del pacto político; sociedad prepolítica; sociedad incivil; sufrimiento objetivo; amenaza real; miedo; desigual y cualificado reparto del terror y de la negación de los derechos fundamentales por culpa de ETA, el pacto de Lizarra y el nacionalismo independentista. En lugar del derecho a la vida y libertad de un pueblo estaba el derecho a la vida, libertad e igualdad de todos los ciudadanos.

Las coincidencias substanciales en las premisas teóricas, valores, determinación del problema esencial de los ciudadanos vascos y objetivos políticos no se repitieron en la cuestión de gobierno. En El Correo hubo oposición a los gobiernos frentistas y se defendió la imposible transversalidad; en El Mundo se produjo la coincidencia básica entre editoriales y comentarios a favor del gobierno de alternancia; y en $E l$ País se dio el fenómeno contrario, los comentaristas defendieron mayoritariamente el gobierno de populares y socialistas sin nacionalistas en contra de la opinión oficial del periódico.

La responsabilidad, culpabilidad y complicidad del PNV en el problema vasco fue criterio común de toda esta prensa por la tergiversación y manipulación de la historia, negación del pluralismo, desprotección de parte de la sociedad e indiferencia ante el terrorismo, aprovechamiento de la violencia para sus intereses, ruptura del consenso, impunidad y tutela de ETA, despotismo, política de exclusión, mentiras, prioridad de los objetivos nacionalistas sobre la defensa de las víctimas, situación de protegido de ETA, sin compasión por las víctimas, irresponsabilidad ante el sufrimiento, banalización del mal, oscurantismo y carlismo antiilustrado. La atribución al PNV de un totalitarismo idéntico al de ETA sólo apareció en algún comentario de El Mundo.

4. El nacionalismo daba una respuesta abstracta, sin sentido y de imposible aceptación al sufrimiento objetivo de muchos y a la concul- 
cación de sus derechos. La patria agobiante y virtual de los nacionalistas actuaba contra los derechos y libertades de los ciudadanos. La mitología nacionalista del PNV (y coalición), su estrategia de convergencia política con los radicales y su incapacidad para prescindir de ETA lo convertían en definitiva en el problema de un País Vasco carente de los fundamentos de una sociedad democrática y libre por causa de ETA. La independencia podía ser la tiranía. El nacionalismo era la causa no justificada de la sociedad violenta, dividida y enfrentada, que la retrotraía a la situación prepolítica por la ruptura del pacto fundamental y constituyente del que eran expresión la Constitución y el Estatuto. El nacionalismo no era progresismo, sino reacción, y el nacionalismo etnicista era integrismo puro. La fractura de la sociedad vasca no era espontánea, ya que había más cosas en común que diferentes, sino que venía producida por las direcciones o élites nacionalistas, que confirmarían la maleabilidad de las masas mediante el instrumento de la ideología nacionalista.

5. A esta interpretación del nacionalismo y de los partidos nacionalistas abrumadoramente mayoritaria en los periódicos indicados acompañó, en menor escala, la crítica a los Partidos Popular y Socialista y, especialmente, al gobierno central del Partido Popular. Destacó en esta labor el diario El País, que omitió prácticamente, por el contrario, críticas a los socialistas. En El Correo hubo una notable pluralidad de artículos de opinión. En él se expresaron ideas y proyectos nacionalistas - faltos de un adecuado desarrollo y maduración- que, por el contrario, no tuvieron su sede en los periódicos nacionalistas, tal vez, por su aparente, más que real, renovación que podía ser interpretada como una crítica a la ortodoxia nacionalista. En realidad, tales aportaciones nacionalistas eran incompatibles y contradictorias con el nacionalismo oficial. La nación plural vasca no añadía ningún elemento de legitimación a la nada democrática categoría de nación, ni a su delimitación territorial como sujeto de la soberanía, aunque servía para ahuyentar los fantasmas de la opresión, incultura, antipluralismo y desprecio a la libertad. También El País acogió ideas nacionalistas. La homogeneidad ideológica de los artículos de opinión de El Mundo fue muy alta y no hubo concesiones a opiniones nacionalistas. Tanto El País como El Correo tuvieron la decencia de no admitir insultos en sus páginas. Los que aparecieron en El Mundo no fueron comparables a la exhibición hecha en Deia.

6. Las cuantificaciones, especialmente el número de análisis y la distribución por materias, que se han hecho a lo largo del trabajo dan 
idea de la función del periódico y de la relación entre éste y el lector. La combinación de ambos criterios, pocos análisis con alta presencia de la crítica a los Partidos no afectos al periódico, muestran una preferencia por los procedimientos propagandísticos — repetición de las campañas nacionalistas, denuncias cortas, slogans, críticas breves y muy repetidas, acusaciones concisas, insultos - a costa de la argumentación racional propia del análisis, que coincide con la importancia — número y calidad - mayor o menor de los editoriales. En este sentido, la prensa nacionalista es mucho más propagandística que el resto de periódicos. Hay un silencio comparativo, además, en los periódicos nacionalistas con respecto a la justificación teórica del nacionalismo, lo que apoyaría la tesis académica de que la ideología nacionalista no sólo es peligrosa por falsa, sino porque se da por evidente y obvia.

7. El estudio realizado permite confirmar la relación secuencial y dependiente, absolutamente lógica, entre las premisas teóricas, la naturaleza del problema, los objetivos de la legislatura y la responsabilidad de los partidos. Frente al particularismo ideológico de la noción de pueblo o nación se presenta el universalismo de los derechos humanos y fundamentales. La negación del derecho del pueblo a la independencia - problema - se contrapone a la negación de los derechos de las personas; la libertad nacional se contrapone a la libertad del ciudadano; la palabra de la nación se contrapone a la palabra de las víctimas. Al objetivo del soberanismo se opone la restauración de los derechos individuales. Y a la responsabilidad del españolismo se contesta con la responsabilidad del nacionalismo (ideología, premisas teóricas), de ETA y su terrorismo (causa) y del PNV/EA (estrategia de complicidad).

8. La idea básica que cabe establecer en este trabajo es fruto de las aportaciones de todas las campañas y de toda la prensa analizada. Para quienes de forma gratuita e infundada definen la historia y la realidad social a partir de las premisas jusnaturalistas o sociobiológicas, que hablan de naciones naturales o divinas, aunque sea para fines revolucionarios, la creencia en la nación soberana e independiente permite presentarla como la condición imprescindible y necesaria de la realización de cualquier otro valor. Según esto, el derecho de la nación no es uno más que se suma al listado de derechos fundamentales, sino su condición previa y fundamento. El derecho a la paz, así mismo, tiene por requisito a la nación. No hace falta despreciar los derechos humanos. Se puede defenderlos con convicción, pero la primacía axiológica y fundacional de la nación — que es lo que no se justifica - sirve de justifica- 
ción del uso de la violencia y de cualquier estrategia que pretenda realizar el objetivo del nacionalismo sin supeditarlo a la previa realización de la paz y de los derechos fundamentales. El dogmatismo de esta ideología impide definir el problema de la sociedad vasca como una destrucción de la convivencia y violación del derecho a la igualdad ante la vida y libertad por más que los datos empíricos así lo confirmen, porque hay un algo que le precede y le acompaña, el problema político irresuelto de la nación. Impide también la unión de los demócratas, ya que son muchos los que no creen ni pueden creer en semejante sistema ideológico, no están dispuestos a su desarrollo y lo consideran un impedimento para la realización de los derechos. Hace imposible el diálogo, porque la nación o se acepta o se rechaza, pero no deja nada para la discusión y bloquea la elemental pregunta de si la nación étnica o territorial es, de hecho, causa o excusa de violación de los derechos de las personas. Por el contrario, da falsamente justificación a una interpretación por la que la denuncia de la violación de los derechos fundamentales por el terrorismo se utiliza como disculpa para destruir definitivamente las aspiraciones de la nación y todo cuanto acompaña a la nación, los movimientos y los partidos nacionalistas. El que rechaza a la nación, rechaza al partido que la defiende y sus pretensiones de gobierno y convierte a tal partido nacionalista y al nacionalismo en el objetivo a destruir. Ello da lugar a la imagen del perseguido. Y el que se opone al grupo de creyentes es el enemigo. Esta es la aplicación de la ideología nacionalista que los políticos y la prensa nacionalista hicieron a la campaña. Desde esta perspectiva desaparece toda interpretación objetiva de la realidad, se produce el fenómeno del «ojo ciego» y el pragmatismo que relativiza a las ideologías por su utilidad ante los valores ni existe ni puede existir. La simpleza del sistema de creencias no se corresponde con la fecundidad de su funcionalidad en la lucha por el poder que es toda elección, pues define los fines y el problema de la realidad social y política, impide el debate sobre la justicia reduciéndolo a las reivindicaciones más elementales y crea la mística de la persecución y de la salvación. La ideología de salvación se aplica como ideología de poder, que - convertida en mentalidad y concienciamanipula a las masas y convierte a sus partidos en sociedades anónimas de administración de los intereses del «pueblo».

El mito del pueblo o nación que en su formulación decimonónica occidental contribuyó - con sus secuelas de daños y perjuicios- a satisfacer intereses particulares y generales en los largos procesos de modernización e industrialización, creando con ello su legitimidad, muestra en esta parte de la Europa occidental su carácter particular, incivil, destructor de la solidaridad social y políticamente disfuncional. 
Las interpretaciones académicas de que el nacionalismo es una ideología de poder que debe ser tratada y analizada como tal o que en lugar de una comunidad fraternal es una sociedad anónima de intereses, o que no necesita de la nación para existir o que es un instrumento de manipulación de las masas al servicio del poder de las élites, tienen sobrados fundamentos en la prensa analizada, como también lo tiene la afirmación de que los términos nación, pueblo, patria e identidad, tal como los usa el nacionalismo, carecen de valor analítico. 